\title{
A [3+3] Annelation Approach to Tetrahydropyridines
}

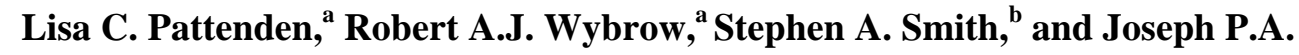

$$
\text { Harrity }^{*} \text {,a }
$$

${ }^{a}$ Department of Chemistry, University of Sheffield, Brook Hill, Sheffield S3 7HF, U.K., and ${ }^{b}$ GlaxoSmithKline Research and Development, Gunnels Wood Road, Stevenage, Hertfordshire, SG1 $2 N Y, U . K$.

\section{Supporting Information}

Table of Contents

$\begin{array}{ll}\text { General considerations } & 2\end{array}$

Preparation of the Büchi Grignard Reagent 5

Data for 9

Data for $11 \quad 6$

$\begin{array}{ll}\text { Data for } 13 & 7\end{array}$

Data for $14 \quad 8$

Data for $16 \quad 9$

$\begin{array}{ll}\text { Data for } 17 & 10\end{array}$

$\begin{array}{lr}\text { Data for } 19 & 10\end{array}$

$\begin{array}{ll}\text { Data for } 20 & 11\end{array}$

Data for $22 \quad 12$

$\begin{array}{ll}\text { Data for } 23 & 13\end{array}$

$\begin{array}{lr}\text { Data for } 25 & 14\end{array}$

$\begin{array}{ll}\text { Data for } 26 & 15\end{array}$

$\begin{array}{ll}\text { Data for } 28 & 15\end{array}$

$\begin{array}{lr}\text { Data for } 29 & 16\end{array}$ 
$\begin{array}{ll}\text { Data for } 30 & 17\end{array}$

$\begin{array}{ll}\text { Data for } 31 & 18\end{array}$

$\begin{array}{lr}\text { Data for } 32 & 19\end{array}$

$\begin{array}{lr}\text { Data for } 33 & 20\end{array}$

Data for 2-methyl-6-propyl-1-(toluene-4-sulfonyl)-piperidine 21

$\begin{array}{ll}{ }^{1} \mathrm{H} /{ }^{13} \mathrm{C} \text { NMR Spectra of } 9 & 22 / 23\end{array}$

$\begin{array}{ll}{ }^{1} \mathrm{H} /{ }^{13} \mathrm{C} \text { NMR Spectra of } 11 & \text { 24/25 }\end{array}$

${ }^{1} \mathbf{H} /{ }^{13} \mathrm{C}$ NMR Spectra of $13 \quad 26 / 27$

${ }^{1} \mathrm{H} /{ }^{13} \mathrm{C}$ NMR Spectra of $14 \quad 28 / 29$

${ }^{1} \mathrm{H} /{ }^{13} \mathrm{C}$ NMR Spectra of $16 \quad 30 / 31$

${ }^{1} \mathbf{H} /{ }^{13} \mathrm{C}$ NMR Spectra of $17 \quad 32 / 33$

${ }^{1} \mathbf{H} /{ }^{13} \mathrm{C}$ NMR Spectra of $19 \quad 34 / 35$

${ }^{1} \mathrm{H} /{ }^{13} \mathrm{C}$ NMR Spectra of $20 \quad 36 / 37$

${ }^{1} \mathrm{H} /{ }^{13} \mathrm{C}$ NMR Spectra of $22 \quad 38 / 39$

${ }^{1} \mathrm{H} /{ }^{13} \mathrm{C}$ NMR Spectra of $23 \quad 40 / 41$

${ }^{1} \mathrm{H} /{ }^{13} \mathrm{C}$ NMR Spectra of $25 \quad 42 / 43$

${ }^{1} \mathrm{H} /{ }^{13} \mathrm{C}$ NMR Spectra of $26 \quad 44 / 45$

${ }^{1} \mathrm{H} /{ }^{13} \mathrm{C}$ NMR Spectra of $28 \quad 46 / 47$

$\begin{array}{ll}{ }^{1} \mathrm{H} /{ }^{13} \mathrm{C} \text { NMR Spectra of } 29 & 48 / 49\end{array}$

${ }^{1} \mathrm{H} /{ }^{13} \mathrm{C}$ NMR Spectra of $30 \quad 50 / 51$

${ }^{1} \mathrm{H} /{ }^{13} \mathrm{C}$ NMR Spectra of $31 \quad 52 / 53$

${ }^{1} \mathrm{H} /{ }^{13} \mathrm{C}$ NMR Spectra of $32 \quad 54 / 55$

${ }^{1} \mathrm{H} /{ }^{13} \mathrm{C}$ NMR Spectra of $33 \quad 56 / 57$

$\begin{array}{ll}{ }^{1} \mathrm{H} /{ }^{13} \mathrm{C} \text { NMR Spectra of } 34 & 58 / 59\end{array}$

Chromatograms:

$\begin{array}{ll}\text { (R)- } 11 & 60\end{array}$

$\begin{array}{ll}\text { Racemic- } 11 & 61\end{array}$

X-Ray Data $30 \quad 62$ 


\section{General Considerations}

All reactions were conducted in oven or flame-dried glassware under an inert atmosphere of dry nitrogen. Flash chromatography was performed on silica gel (Davisil). Thin layer chromatography (TLC) was performed on aluminium backed plates pre-coated with silica $\left(0.2 \mathrm{~mm}\right.$, Merck DC-alufolien Kieselgel $\left.60 \mathrm{~F}_{254}\right)$ which were developed using standard visualizing agents: Ultra Violet light or potassium permanganate

${ }^{1} \mathrm{H}$ NMR spectra were recorded on a Bruker AC-250 (250 MHz) or AMX-400 (400 $\mathrm{MHz}$ ) supported by an Aspect 3000 data system, unless otherwise stated. Chemical shifts are reported in ppm with the solvent resonance as the internal standard $\left(\mathrm{CHCl}_{3}\right.$ : $\delta 7.27 \mathrm{ppm})$. Data are reported as follows: chemical shift, integration, multiplicity ( $\mathrm{s}=$ singlet, $\mathrm{d}=$ =doublet, $\mathrm{t}=$ triplet, $\mathrm{q}=$ quartet, $\mathrm{br}=$ broad, $\mathrm{m}=$ =multiplet) and coupling constants $(J)$ in $\mathrm{Hz}$.

${ }^{13} \mathrm{C}$ NMR spectra were recorded on a Bruker AC-250 (62.9 MHz) or AMX-400 (100.6 MHz) with complete proton decoupling. Chemical shifts are reported in ppm with the solvent resonance as the internal standard $\left(\mathrm{CDCl}_{3}: \delta 77.0 \mathrm{ppm}\right)$.

Infrared (FTIR) spectra were recorded on a Perkin Elmer Paragon 100 FTIR spectrophotometer, $v_{\max }$ in $\mathrm{cm}^{-1}$. Bands are characterized as broad (br), strong (s), medium (m) and weak (w). Samples were recorded as thin films using sodium chloride plates, as a DCM solution.

Low resolution mass spectra were recorded on Micromass Autospec, operating in E.I., C.I. or FAB mode; or a Perkin-Elmer Turbomass Benchtop GC-MS operating in either E.I. or C.I mode. High-resolution mass spectra (HRMS) recorded for accurate mass analysis, were performed on either a MicroMass LCT operating in Electrospray mode $\left(\mathrm{TOF}_{\mathrm{ES}}^{+}\right)$or a MicroMass Prospec operating in either $\mathrm{FAB}\left(\mathrm{FAB}^{+}\right)$, EI $\left(\mathrm{EI}^{+}\right)$or $\mathrm{CI}\left(\mathrm{CI}^{+}\right)$mode. 
Elemental microanalysis performed using a Perkin-Elmer 2400 CHNS / O Series II Elemental Analyser.

Melting points were performed on recrystallised solids, were recorded on a Gallenkamp melting point apparatus and are uncorrected.

All solvents and reagents were purified using standard laboratory techniques according to methods published in "Purification of Laboratory Chemicals" by Perrin, Armarego, and Perrin (Pergamon Press, 1966). Aziridines were prepared by methods previously reported. ${ }^{1}$

\section{Purification of solvents and reagents}

Solvents and reagents were used either as received from commercial suppliers or, when necessary, purified in accordance with standard procedures as outlined below.

Dichloromethane was freshly distilled from calcium hydride immediately prior to use.

Diethyl ether (anhydrous grade) was distilled from sodium metal / benzophenone ketyl immediately prior to use.

Petroleum ether refers to $40-60{ }^{\circ} \mathrm{C}$ petroleum distillates, which was distilled prior to use.

Tetrahydrofuran (anhydrous grade) was distilled from sodium metal / benzophenone ketyl immediately prior to use.

Triethylamine was distilled from potassium hydroxide and stored over $4 \AA$ molecular sieves.

Methanol was distilled from magnesium and iodine immediately prior to use.

Acetone was distilled from Drierite.

\footnotetext{
${ }^{1}$ (a) Goodenough, K. M., Raubo, P., Harrity, J. P. A., Org. Lett. 2005, 7, 14, 2993. (b) Jeong, J. U., Tao, B., Sagesser, I., Henniges, H., and Sharpless, B., J. Am. Chem. Soc., 1998, 120, 6844. (c) Berry, M. B., Craig, D., Synlett, 1992, 41
} 


\section{Preparation of the Büchi Grignard Reagent:}

To a $50 \mathrm{~mL}$ two-necked flask fitted with a reflux condenser was added magnesium turnings (484 mg, $17.25 \mathrm{mmol}, 1.7 \mathrm{eq})$ and THF (10 mL), then 2-(2-bromo-ethyl)[1,3]dioxolane (1.2 mL, $10.2 \mathrm{mmol}, 1 \mathrm{eq})$ was added. The solution was allowed to cool to room temperature and the concentration of the Büchi Grignard solution assessed by titration. ${ }^{2}$ An aliquot was removed and placed into a separate flask.

\section{Synthesis of (R)-N-(1-Benzyl-4-[1,3]dioxolan-2-yl-butyl)-4-methyl- benzenesulfonamide 9}

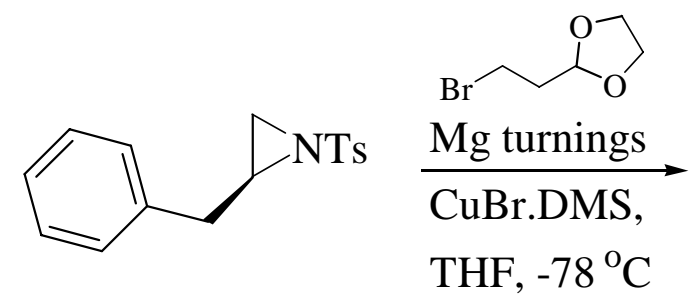

8<smiles>[NH3+][C@H](CCCC1OCCO1)Cc1ccccc1</smiles>

9

A solution of CuBr.DMS (93 mg, $0.45 \mathrm{mmol}, 0.4 \mathrm{eq})$ in DMS (1 mL) was added to the Büchi Grignard solution (1.8 mL, $0.4 \mathrm{M}, 0.72 \mathrm{mmol}, 2 \mathrm{eq})$ at $-78{ }^{\circ} \mathrm{C}$ and stirred for 1 hour. Then a solution of 8 (103 mg, $0.36 \mathrm{mmol}, 1 \mathrm{eq})$ in THF ( $1 \mathrm{~mL}$ ) was added at $-78{ }^{\circ} \mathrm{C}$ and stirred for 10 minutes. The solution was left stirring and allowed to warm to room temperature overnight. The reaction was quenched with water and the organic layer was separated. The aqueous layer was re-extracted with ethyl acetate (2 portions), the organic layers were combined and washed with brine. The solution was dried over $\mathrm{MgSO}_{4}$ and concentrated under reduced pressure. The residue was purified by column chromatography (using a continuous gradient from petroleum ether and ending with 5:1 petroleum ether/ethyl acetate) to give $\mathbf{9}$ as a white solid, $138 \mathrm{mg}$ (98\%).

Mp $115-116{ }^{\circ} \mathrm{C}$

$[\alpha]^{25}-13\left(\right.$ c $\left.1.0 \mathrm{~g} / \mathrm{mL}, \mathrm{CH}_{2} \mathrm{Cl}_{2}\right)$.

\footnotetext{
${ }^{2}$ Titration carried out with $31 \mathrm{mg}$ (DL)-menthol, 5mg 1,10-phenanthroline and $1.5 \mathrm{~mL}$ THF creating a $2 \mathrm{mmol}$ solution. The Grignard solution was added to the solution until a red-purple colour persisted. The molarity was calculated by dividing 0.2 by the amount in $\mathrm{mL}$ used to achieve the colour change. See Lin, H., Paquette, L. A., Synth. Commun, 1994, 24, 17, 2503
} 
${ }^{1} \mathrm{H}$ NMR (250 MHz, $\left.\mathrm{CDCl}_{3}\right): \delta$ 1.13-1.51 (6H, m), 2.33 (3H, s), 2.59 (2H, d, J=6.5 Hz), 3.25-3.45 (1H, m), 3.67-3.89 (4H, m), 4.51 (1H, d, $J=8.0$ Hz), 4.64 (1H, t, J=4.5 Hz), 6.87-6.98 (2H, m), 7.06-7.21 (5H, m), 7.57 (2H, d, $J=8.0 \mathrm{~Hz})$.

${ }^{13} \mathrm{C}$ NMR (62.9 MHz, $\left.\mathrm{CDCl}_{3}\right): \delta 19.8,21.5,33.3,34.1,41.2,54.9,64.8,104.2,126.5$, 127.0, 128.5, 129.5, 129.6, 137.2, 137.8, 143.1.

FTIR (thin film): 3279 (br), 2950 (s), 2877 (s), 1599 (m), 1495 (m), 1454 (s), 1417 (s), 1327 (s), 1158 (s), 1091 (s), 1030 (s), 946 (m) cm².

HRMS (TOF ES) calcd. for $\mathrm{C}_{21} \mathrm{H}_{27} \mathrm{NO}_{4} \mathrm{SNa}\left(\mathrm{MNa}^{+}\right)$: 412.1559. Found: 412.1553.

Anal. Calcd. For: $\mathrm{C}_{21} \mathrm{H}_{27} \mathrm{NO}_{4} \mathrm{~S}$ : C, 64.75; H, 6.99; N, 3.60; S, 8.23; Found: C, 64.48; H, 7.25; N, 3.56; S, 8.35.

\section{Synthesis of (R)-2-Benzyl-1-(toluene-4-sulfonyl)-1,2,3,4-tetrahydropyridine 11}<smiles>CC(C)C(=O)OC1COC(CCC[C@H](Cc2ccccc2)NS(=O)(=S)c2ccccc2)O1</smiles>

An aqueous solution of hydrogen chloride (1M, $2 \mathrm{~mL}, 2.0 \mathrm{mmol}, 7.5 \mathrm{eq})$ was added to a solution of 9 (104 mg, $0.267 \mathrm{mmol}, 1 \mathrm{eq})$ in acetone (2 mL) and stirred overnight at room temperature. Reaction was quenched with a saturated solution of $\mathrm{K}_{2} \mathrm{CO}_{3}$ and the product was extracted with ethyl acetate, dried over $\mathrm{MgSO}_{4}$ and concentrated under reduced pressure. The residue was purified by column chromatography (using a continuous gradient from petroleum ether and ending with 19:1 petroleum ether/ethyl acetate) to give $\mathbf{1 1}$ as a colourless solid, $77 \mathrm{mg}(88 \%)$.

Mp 106-108 ${ }^{\circ} \mathrm{C}$.

$[\alpha]^{25}+290\left(\right.$ c $\left.1.0 \mathrm{~g} / \mathrm{mL}, \mathrm{CH}_{2} \mathrm{Cl}_{2}\right)$.

${ }^{1} \mathrm{H}$ NMR (250 MHz, $\left.\mathrm{CDCl}_{3}\right): \delta$ 0.72-0.90 (1H, m), 1.28-1.42 (1H, m), $1.74(1 \mathrm{H}, \mathrm{dt}$, $J=18.5,5.5 \mathrm{~Hz}$ ), 192-2.12 (1H, m), 2.33 (3H, s), 2.66 (1H, dd, $J=13.5,10.5 \mathrm{~Hz}), 2.92$ (1H, dd, J=13.5, 5.0 Hz), 3.98-4.10 (1H, m), 4.94-5.05 (1H, m), 6.62 (1H, d, J=8.0 $\mathrm{Hz}), 7.09-7.29$ (7H, m), 7.60 (2H, d, $J=8.0 \mathrm{~Hz})$.

${ }^{13} \mathrm{C}$ NMR (62.9 MHz, $\left.\mathrm{CDCl}_{3}\right): \delta 17.1,20.9,21.5,38.1,54.3,108.2,123.6,126.5$, 126.9, 128.5, 129.4, 129.7, 136.3, 138.0, 143.4. 
FTIR (thin film): 3086 (m), 3063 (m), 3028 (s), 2927 (s), 2857 (s), 1917 (w), 1807

(w), 1737 (m), 1646 (s), 1597 (s), 1495 (s), 1455 (s), 1401 (s), 1344 (s), 1305 (s),

1261 (s), 1167 (s), 1098 (s), 1049 (s), 1018 (s), 954 (s), 930 (s).

HRMS (TOF ES) calcd. for $\mathrm{C}_{19} \mathrm{H}_{23} \mathrm{NO}_{2} \mathrm{~S}\left(\mathrm{MH}^{+}\right)$: 328.1371. Found: 328.1386.

Anal. Calcd. For: $\mathrm{C}_{19} \mathrm{H}_{22} \mathrm{NO}_{2} \mathrm{~S}$ : C, 69.69; H, 6.46; N, 4.28; S, 9.79; Found: C, 69.53;

H, 6.53; N, 4.26; S, 9.84.

\section{Synthesis of (S)-N-(4-[1,3]dioxolan-2-yl-1-methyl-butyl)-4-methyl- benzenesulfonamide 13}

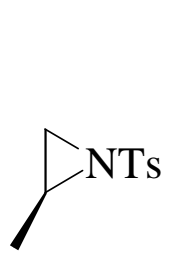

12

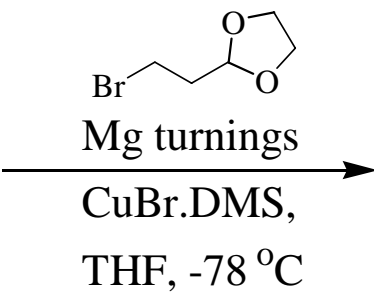

THF, $-78{ }^{\circ} \mathrm{C}$

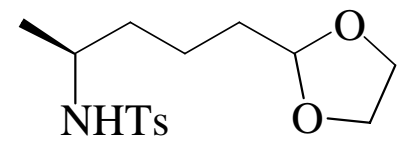

13

A solution of CuBr.DMS (135 mg, $0.66 \mathrm{mmol}, 0.4 \mathrm{eq})$ in DMS (2 mL) was added to the Büchi Grignard solution (7 mL, $0.47 \mathrm{M}, 3.29 \mathrm{mmol}, 2 \mathrm{eq}$ ) at $-78{ }^{\circ} \mathrm{C}$ and stirred for 1 hour. Then a solution of 12 (347 mg, $1.65 \mathrm{mmol}, 1 \mathrm{eq}$ ) in THF (3 mL) was added at $-78{ }^{\circ} \mathrm{C}$ and stirred for 10 minutes. The solution was left stirring and allowed to warm to room temperature overnight. The reaction was quenched with water and the organic layer was separated. The aqueous layer was re-extracted with ethyl acetate (2 portions), the organic layers were combined and washed with brine. The solution was dried over $\mathrm{MgSO}_{4}$ and concentrated under reduced pressure. The residue was purified by column chromatography (using a continuous gradient from petroleum ether and ending with 5:1 petroleum ether/ethyl acetate) to give $\mathbf{1 3}$ as a white solid, $360 \mathbf{m g}$ (70\%).

Mp 89-93 ${ }^{\circ} \mathrm{C}$

$[\alpha]^{25}-27\left(c 0.009 \mathrm{~g} / \mathrm{mL}, \mathrm{CH}_{2} \mathrm{Cl}_{2}\right)$.

${ }^{1} \mathrm{H}$ NMR (250 MHz, $\mathrm{CDCl}_{3}$ ): $\delta 1.03$ (3H, d, J=6.5 Hz), 1.21-1.71 (6H, m), 2.42 (3H, s), 3.21-3.39 (1H, m), 3.78-3.97 (4H, m), $4.33(1 \mathrm{H}, \mathrm{d}, J=8.0 \mathrm{~Hz}), 4.75(1 \mathrm{H}, \mathrm{t}, \mathrm{J}=4.5$ $\mathrm{Hz})$, 7.26-7.32 (2H, m), 7.72-7.78 (2H, m).

${ }^{13} \mathrm{C}$ NMR (62.9 MHz, $\left.\mathrm{CDCl}_{3}\right): \delta$ 20.0, 21.5, 21.6, 33.3, 37.2, 49.9, 64.8, 104.2, 127.0, 129.6, 138.2, 143.1. 
FTIR (thin film): 3272 (br), 2950 (m), 1323 (m), 1160 (s), 1092 (m), 1030 (w) cm . m/z (TOF ES): 252, 320, $336\left(\mathrm{MNa}^{+}\right)$. HRMS (TOF ES) calcd. for $\mathrm{C}_{15} \mathrm{H}_{23} \mathrm{NO}_{4} \mathrm{SNa}$ $\left(\mathrm{MNa}^{+}\right)$: 336.1245. Found: 336.1259.

\section{Synthesis of (S)-2-methyl-1-(toluene-4-sulfonyl)-1,2,3,4-tetrahydropyridine 14}

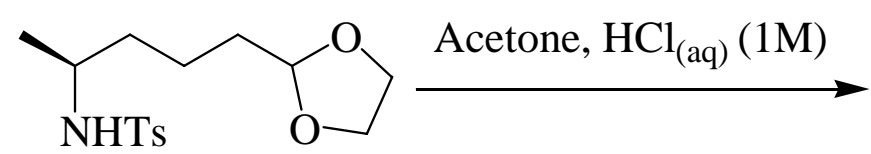

13<smiles>CC1CCC=CN1[AsH3]</smiles>

14

An aqueous solution of hydrogen chloride (1M, $1.4 \mathrm{~mL}, 1.40 \mathrm{mmol}, 7.7 \mathrm{eq})$ was added to a solution of 13 (56 mg, $0.18 \mathrm{mmol}, 1 \mathrm{eq})$ in acetone (3.6 mL) and stirred overnight at room temperature. Reaction was quenched with a saturated solution of $\mathrm{K}_{2} \mathrm{CO}_{3}$ and the product was extracted with ethyl acetate, dried over $\mathrm{MgSO}_{4}$ and concentrated under reduced pressure. The residue was purified by column chromatography (using a continuous gradient from petroleum ether and ending with 19:1 petroleum ether/ethyl acetate) to give $\mathbf{1 4}$ as a yellow oil, $38 \mathrm{mg}(84 \%)$.

Rotation $[\alpha]^{25}+511\left(c 0.009 \mathrm{~g} / \mathrm{mL}, \mathrm{CH}_{2} \mathrm{Cl}_{2}\right)$.

${ }^{1} \mathrm{H}$ NMR (250 MHz, $\mathrm{CDCl}_{3}$ ): $\delta$ 0.99-1.12 (1H, m), 1.17 (3H, d, J=6.5 Hz), 1.38-1.49 (1H, m), 1.56-1.89 (1H, m), 1.75-2.08 (1H, m), 2.41 (3H, s), 4.02-4.15 (1H, m), 4.945.02 (1H, m), 6.58-6.65 (1H, m), 7.29 (2H, d, $J=8.0 \mathrm{~Hz}), 7.68$ (2H, d, $J=8.0 \mathrm{~Hz})$.

${ }^{13} \mathrm{C}$ NMR (62.9 MHz, $\left.\mathrm{CDCl}_{3}\right): \delta 16.9,18.2,21.5,25.2,48.5,107.7,123.2,126.8$, 129.6, 136.4, 143.3.

FTIR (thin film): 3063 (w), 2977 (m), 2929 (m), 2848 (w), 1645 (m), 1362 (s), 1340 (s), 1262 (m), 1170 (s), 1136 (m), 1103 (s) $\mathrm{cm}^{-1}$. m/z (TOF ES): $252\left(\mathrm{MH}^{+}\right), 274\left(\mathrm{MNa}^{+}\right)$. HRMS (TOF ES) calcd. for $\mathrm{C}_{13} \mathrm{H}_{18} \mathrm{NO}_{2} \mathrm{~S}$ $\left(\mathrm{MH}^{+}\right)$: 252.1058. Found: 252.1048. 


\section{Synthesis of N-(4-[1,3]dioxolan-2-yl-1-isopropyl-butyl)-4-methyl- benzenesulfonamide 16}

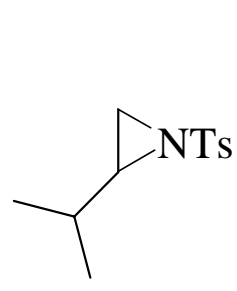

15<smiles>BrCCC1OCCO1</smiles>

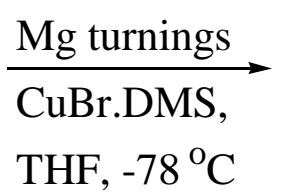

THF, $-78{ }^{\circ} \mathrm{C}$

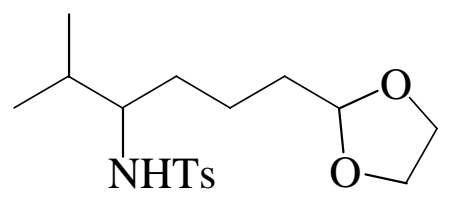

16

A solution of CuBr.DMS (137 mg, $0.67 \mathrm{mmol}, 0.4 \mathrm{eq})$ in DMS (2 mL) was added to the Büchi Grignard solution ( $8 \mathrm{~mL}, 0.4 \mathrm{M}, 3.33 \mathrm{mmol}, 2 \mathrm{eq}$ ) at $-78{ }^{\circ} \mathrm{C}$ and stirred for 1 hour. Then a solution of 15 (396 mg, $1.67 \mathrm{mmol}, 1 \mathrm{eq}$ ) in THF (2 mL) was added at $-78{ }^{\circ} \mathrm{C}$ and stirred for 10 minutes. The solution was left stirring and allowed to warm to room temperature overnight. The reaction was quenched with water and the organic layer was separated. The aqueous layer was re-extracted with ethyl acetate (2 portions), the organic layers were combined and washed with brine. The solution was dried over $\mathrm{MgSO}_{4}$ and concentrated under reduced pressure. The residue was purified by column chromatography (using a continuous gradient from petroleum ether and ending with 5:1 petroleum ether/ethyl acetate) to give $\mathbf{1 6}$ as a white solid, $469 \mathbf{m g}$ (82\%).

mp $117-120{ }^{\circ} \mathrm{C}$

${ }^{1} \mathrm{H}$ NMR (250 MHz, $\left.\mathrm{CDCl}_{3}\right): \delta 0.78(6 \mathrm{H}, \mathrm{d}, J=6.5 \mathrm{~Hz}), 1.04-1.80(7 \mathrm{H}, \mathrm{m}), 2.41(3 \mathrm{H}$, s), 3.01-3.13 (1H, m), 3.75-3.96 (4H, m), $4.30(1 \mathrm{H}, \mathrm{d}, J=9.0 \mathrm{~Hz}), 4.69(1 \mathrm{H}, \mathrm{t}, J=4.5$ Hz), 7.29 (2H, d, $J=8.5 \mathrm{~Hz}), 7.75$ (2H, d, $J=8.5 \mathrm{~Hz}$ ).

${ }^{13} \mathrm{C}$ NMR (62.9 MHz, $\left.\mathrm{CDCl}_{3}\right): \delta 17.5,18.3,20.1,21.5,31.0,31.4,33.4,59.1,64.8$, 104.2, 127.0, 129.5, 138.6, 142.9 .

FTIR (thin film): 3281 (w), 2958 (m), 2875 (m), 1323 (s), 1160 (s), 1093 (s), 1029 (s) $\mathrm{cm}^{-1}$.

m/z (TOF ES): 280, $364\left(\mathrm{MNa}^{+}\right)$. HRMS (TOF ES) calcd. for $\mathrm{C}_{17} \mathrm{H}_{27} \mathrm{NO}_{4} \mathrm{SNa}$ $\left(\mathrm{MNa}^{+}\right)$: 364.1559. Found: 364.1553. 
Synthesis of 2-isopropyl-1-(toluene-4-sulfonyl)-1,2,3,4-tetrahydropyridine 17

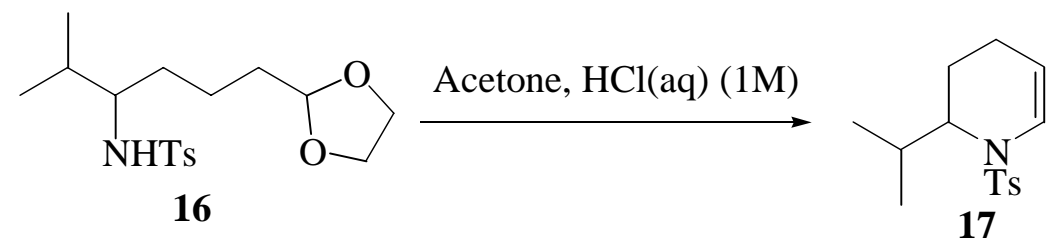

An aqueous solution of hydrogen chloride (1 M, $4 \mathrm{~mL}, 4.0 \mathrm{mmol}, 7.1 \mathrm{eq}$ ) was added to a solution of 16 (190 mg, $0.56 \mathrm{mmol}, 1 \mathrm{eq})$ in acetone $(4 \mathrm{ml})$ and stirred overnight at room temperature. Reaction was quenched with a saturated solution of $\mathrm{K}_{2} \mathrm{CO}_{3}$ and the product was extracted with ethyl acetate, dried over $\mathrm{MgSO}_{4}$ and concentrated under reduced pressure. The residue was purified by column chromatography (using a continuous gradient from petroleum ether and ending with 19:1 petroleum ether/ethyl acetate) to give $\mathbf{1 7}$ as a white solid, $154 \mathrm{mg}$ (98\%).

\section{Mp 84-88 ${ }^{\circ} \mathrm{C}$}

${ }^{1} \mathrm{H}$ NMR (250 MHz, CDCl $): \delta$ 0.61-0.78 (1H, m), 0.90 (3H, d, J=6.5 Hz), $1.11(3 \mathrm{H}$, d, $J=6.5 \mathrm{~Hz}), 1.55-1.97(4 \mathrm{H}, \mathrm{m}), 2.42(3 \mathrm{H}, \mathrm{s}), 3.52\left(1 \mathrm{H}, \mathrm{dt}, J_{1}=10.0 \mathrm{~Hz}, J_{2}=2.5 \mathrm{~Hz}\right)$ 5.05-5.13 (1H, m), 6.54-6.61 (1H, m), 7.31 (2H, d, $J=8.0 \mathrm{~Hz}), 7.68$ (2H, d, $J=8.0 \mathrm{~Hz})$. ${ }^{13} \mathrm{C}$ NMR (62.9 MHz, $\mathrm{CDCl}_{3}$ ): 17.6, 19.0, 20.6, 20.8, 21.5, 27.5, 59.13, 111.4, 123.9, 127.0, 129.6, 136.0, 143.2.

FTIR (thin film): 2961 (m), 1644 (w), 1354 (w), 1340 (s), 1171 (s), 1092 (m) cm cm $^{-1}$ m/z (ES): $280\left(\mathrm{MH}^{+}\right)$. HRMS (ES) calcd. for $\mathrm{C}_{15} \mathrm{H}_{22} \mathrm{O}_{2} \mathrm{~S}\left(\mathrm{MH}^{+}\right)$: 280.1371. Found: 280.1364 .

Synthesis of (S)-2-trimethylsilanyl-ethanesulfonic acid (4-[1,3]dioxolan-2-yl-1methyl-butyl)-amide 19

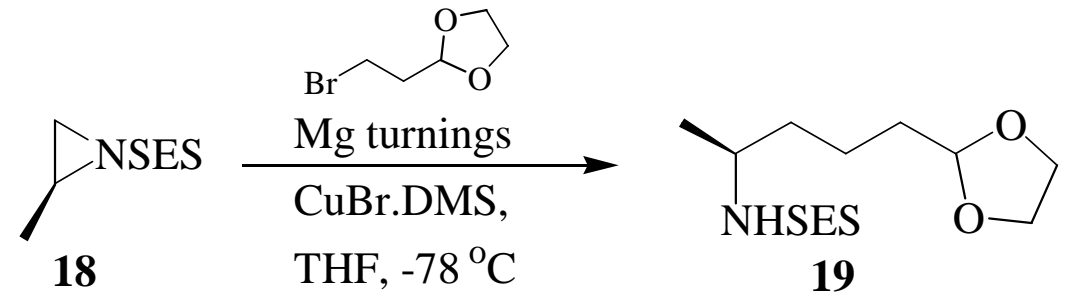

A solution of CuBr.DMS (37 mg, $0.18 \mathrm{mmol}, 0.5 \mathrm{eq})$ in DMS (2 mL) was added to the Büchi Grignard solution (2.8 mL, $0.34 \mathrm{M}, 0.91 \mathrm{mmol}, 2.5 \mathrm{eq})$ at $-78{ }^{\circ} \mathrm{C}$ and stirred 
for an hour. Then a solution of 18 (79 mg, $0.36 \mathrm{mmol}, 1 \mathrm{eq})$ in THF ( $1 \mathrm{~mL}$ ) was added at $-78{ }^{\circ} \mathrm{C}$ and stirred for 10 minutes. The solution was left stirring and allowed to warm to room temperature overnight. The reaction was quenched with water and the organic layer was separated. The aqueous layer was re-extracted with ethyl acetate (2 portions), the organic layers were combined and washed with brine. The solution was dried over $\mathrm{MgSO}_{4}$ and concentrated under reduced pressure. The residue was purified by column chromatography (using a continuous gradient from petroleum ether and ending with 5:1 petroleum ether/ethyl acetate) to give $\mathbf{1 9}$ as a white solid, $102 \mathrm{mg}(88 \%)$.

Mp 76-78 ${ }^{\circ} \mathrm{C}$.

$[\alpha]^{25}{ }_{\mathrm{D}}+40\left(\right.$ c $\left.1.0 \mathrm{~g} / \mathrm{mL}, \mathrm{CH}_{2} \mathrm{Cl}_{2}\right)$.

${ }^{1} \mathrm{H}$ NMR (250 MHz, $\left.\mathrm{CDCl}_{3}\right): \delta-0.30-0.04$ (9H, m), 0.93-1.03 (2H, m), 1.19 (3H, d, $J=6.5 \mathrm{~Hz}), 1.35-1.69(6 \mathrm{H}, \mathrm{m}), 2.82-2.92(2 \mathrm{H}, \mathrm{m}), 3.34-3.47$ (1H, m), 3.75-3.95 (4H, m), 4.79 (1H, d, $J=4.5 \mathrm{~Hz})$.

${ }^{13} \mathrm{C}$ NMR $\left(62.9 \mathrm{MHz}, \mathrm{CDCl}_{3}\right): \delta-2.0,10.7,20.3,22.5,33.4,37.7,50.0,50.2,64.8$, 104.2.

FTIR (thin film): 3544 (w,br), 3278 (br), 2953 (s), 2895 (m), 1316 (s), 1250 (s), 1134 (s), $1027(\mathrm{~m}) \mathrm{cm}^{-1}$.

$\mathrm{m} / \mathrm{z} \quad(\mathrm{TOF} \quad \mathrm{ES}): 346 \quad\left(\mathrm{MNa}^{+}\right), 363 \quad\left(\mathrm{MK}^{+}\right)$. HRMS (TOF ES) calcd. for $\mathrm{C}_{13} \mathrm{H}_{29} \mathrm{NO}_{4} \mathrm{SiSNa}\left(\mathrm{MNa}^{+}\right)$: 346.1484. Found: 346.1497.

\section{Synthesis of (S)-2-methyl-1-(2-trimethylsilanyl-ethanesulfonyl)-1,2,3,4- tetrahydropyridine 20}

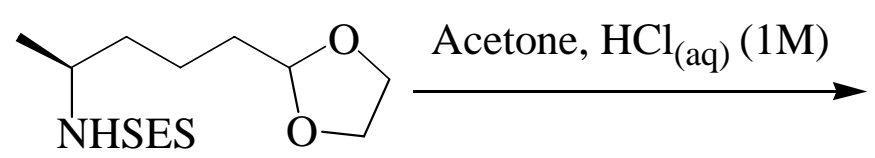

19

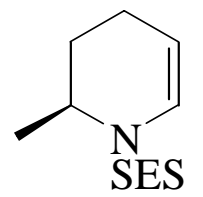

20

An aqueous solution of hydrogen chloride ( $1 \mathrm{M}, 1.1 \mathrm{~mL}, 1.1 \mathrm{mmol}, 8.3 \mathrm{eq})$ was added to a solution of 19 (42 $\mathrm{mg}, 0.13 \mathrm{mmol}, 1 \mathrm{eq})$ in acetone $(1.3 \mathrm{~mL})$ and stirred at room temperature for 5 hours. Reaction was quenched with a saturated solution of $\mathrm{K}_{2} \mathrm{CO}_{3}$ and the product was extracted with ethyl acetate, dried over $\mathrm{MgSO}_{4}$ and concentrated under reduced pressure. The residue was purified by column chromatography (using a 
continuous gradient from petroleum ether and ending with 19:1 petroleum ether/ethyl acetate) to give 20 as a colourless oil, $20 \mathrm{mg}(62 \%)$.

$[\alpha]^{25}+271\left(c 0.009 \mathrm{~g} / \mathrm{mL}, \mathrm{CH}_{2} \mathrm{Cl}_{2}\right)$.

${ }^{1} \mathrm{H}$ NMR (250 MHz, $\mathrm{CDCl}_{3}$ ): $\delta$-0.10-0.10 (9H, m), 0.90-1.03 (2H, m),1.20 (3H, d, $J=6.5 \mathrm{~Hz}), 1.62-1.77$ (2H, m), 1.89-2.17 (2H, m), 2.81-2.95 (2H, m), 4.09-4.21 (1H, m), 4.83-4.91 (1H, m), 6.39-6.46 (1H, m).

${ }^{13} \mathrm{C}$ NMR (62.9 MHz, $\mathrm{CDCl}_{3}$ ): $\delta$-2.0, 10.4, 16.9, 18.4, 26.8, 48.8, 48.9, 105.2, 125.9.

FTIR (thin film): 3508 (br), 2952 (s), 1648 (m), 1337 (s), 1251 (s), 1156 (s), 1100 (m), $1000(\mathrm{~s}) \mathrm{cm}^{-1}$.

m/z (TOF ES): $262\left(\mathrm{MH}^{+}\right)$. HRMS (TOF ES) calcd. for $\mathrm{C}_{11} \mathrm{H}_{24} \mathrm{NO}_{2} \mathrm{SiS}\left(\mathrm{MH}^{+}\right)$: 262.1297. Found: 262.1305.

\section{Synthesis of N-[2-(2-[1,3]dioxolan-2-yl-ethyl)-cyclohexyl]-4-methyl-}

benzenesulfonamide 22

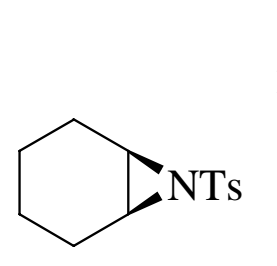

21

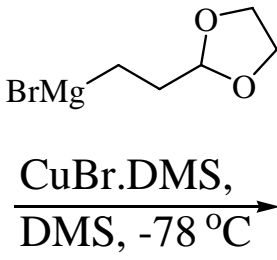

DMS, $-78{ }^{\circ} \mathrm{C}$
$\mathrm{H}^{\prime}$

NHTs

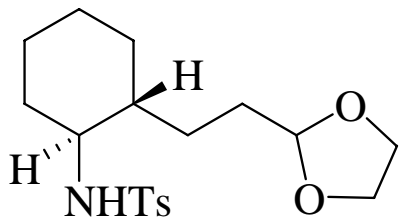

22

A solution of CuBr.DMS (70 mg, $0.34 \mathrm{mmol}, 0.4 \mathrm{eq})$ in DMS ( $1 \mathrm{~mL})$ was added to the Büchi Grignard solution (4 mL, $0.43 \mathrm{M}, 1.70 \mathrm{mmol}, 2 \mathrm{eq}$ ) at $-78{ }^{\circ} \mathrm{C}$ and stirred for an hour. Then a solution of 21 (215 mg, $0.85 \mathrm{mmol}, 1 \mathrm{eq}$ ) in THF (1 mL) was added at $-78{ }^{\circ} \mathrm{C}$ and stirred for 10 minutes. The solution was left stirring and allowed to warm to room temperature overnight. The reaction was quenched with water and the organic layer was separated. The aqueous layer was re-extracted with ethyl acetate (2 portions), the organic layers were combined and washed with brine. The solution was dried over $\mathrm{MgSO}_{4}$ and concentrated under reduced pressure. The residue was purified by column chromatography (using a continuous gradient from petroleum ether and ending with 5:1 petroleum ether/ethyl acetate) to give 22 as a white solid, $234 \mathrm{mg}$ (78\%). 
Mp $170-174{ }^{\circ} \mathrm{C}$

${ }^{1} \mathrm{H}$ NMR (250 MHz, $\left.\mathrm{CDCl}_{3}\right): \delta$ 0.81-1.28 (6H, m), 1.34-1.88 (7H, m), 2.40 (3H, s), 2.73-2.91 (1H, m), 3.74-3.99 (4H, m) 4.50 (1H, d, $J=8.5$ Hz), 4.68 (1H, t, J=4.5 Hz), $7.29(2 \mathrm{H}, \mathrm{d}, J=8.0 \mathrm{~Hz}), 7.76(2 \mathrm{H}, \mathrm{d}, J=8.0 \mathrm{~Hz})$.

${ }^{13} \mathrm{C}$ NMR (62.9 MHz, $\mathrm{CDCl}_{3}$ ): $\delta$ 21.5, 25.0 (x2), 26.4, 30.7, 30.8, 34.6, 42.7, 57.3, 64.8, 104.7, 127.0, 129.6, 138.6, 143.0.

FTIR (thin film): 3268 (br), 2929 (m), 2857 (m), 1325 (m), 1160 (s), 1092 (m), 1072 (w) $\mathrm{cm}^{-1}$.

m/z (ES): 292, $376\left(\mathrm{MNa}^{+}\right), 392\left(\mathrm{MK}^{+}\right), 729\left(2 \mathrm{MNa}^{+}\right)$. HRMS (ES) calcd. for $\mathrm{C}_{18} \mathrm{H}_{27} \mathrm{O}_{4} \mathrm{SNa}\left(\mathrm{MNa}^{+}\right)$: 376.1559. Found: 376.1543.

\section{Synthesis of 1-(toluene-4-sulfonyl)-1,4,4a,5,6,7,8,8a-octahydroquinoline 23}

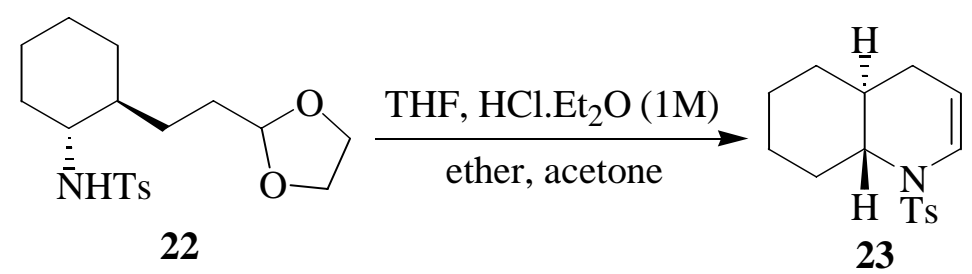

A hydrogen chloride solution in ether $(1 \mathrm{M}, 1.2 \mathrm{~mL}, 1.23 \mathrm{~mol}, 5 \mathrm{eq})$ was added to a solution of 22 (87.2 mg, $0.25 \mathrm{mmol}, 1 \mathrm{eq})$ in ether $(2.5 \mathrm{~mL})$ and acetone $(1 \mathrm{~mL})$. Then THF ( $2 \mathrm{~mL}$ ) was added and stirred at room temperature for 4 hours. Reaction mixture was poured into a saturated solution of $\mathrm{K}_{2} \mathrm{CO}_{3}(10 \mathrm{~mL})$ and the product was extracted with ethyl acetate, dried over $\mathrm{MgSO}_{4}$ and concentrated under reduced pressure. The residue was purified by column chromatography (using a continuous gradient from petroleum ether and ending with 19:1 petroleum ether/ethyl acetate) to give $\mathbf{2 3}$ as a white solid, $45 \mathrm{mg}(63 \%)$.

\section{Mp $71-73{ }^{\circ} \mathrm{C}$}

${ }^{1} \mathrm{H}$ NMR (250 MHz, $\mathrm{CDCl}_{3}$ ): $\delta$ 0.84-1.03 (1H, m), 1.14-1.65 (6H, m), 1.68-1.87 (3H, m), 2.42 (3H, s), 2.63-2.76 (2H, m), 5.00-5.10 (1H, m), 6.67-6.74 (1H, m), $7.31(2 \mathrm{H}$, d, $J=8.5 \mathrm{~Hz}), 7.66(2 \mathrm{H}, \mathrm{d}, J=8.5 \mathrm{~Hz})$.

${ }^{13} \mathrm{C}$ NMR (62.9 MHz, $\mathrm{CDCl}_{3}$ ): $\delta$ 21.6, 25.3 (x2), 28.6, 32.7, 33.3, 39.3, 61.6, 109.1, 127.1, 127.4, 129.5, 135.7, 143.4 . 
FTIR (thin film): 2927 (m), 2855 (m), 1658 (w), 1346 (m), 1241 (w), 1170 (s), 1092 (m) $\mathrm{cm}^{-1}$.

m/z (TOF ES): $292\left(\mathrm{MH}^{+}\right), 314\left(\mathrm{MNa}^{+}\right)$. HRMS (TOF ES) calcd. for $\mathrm{C}_{16} \mathrm{H}_{22} \mathrm{NO}_{2} \mathrm{~S}$ $\left(\mathrm{MH}^{+}\right)$: 292.1371. Found: 292.1359.

\section{Synthesis of N-[1-(3-[1,3]dioxolan-2-yl-propyl)-cyclohexyl]-4-methyl- benzenesulfonamide 25}

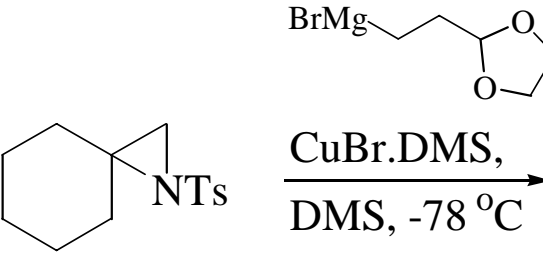

24

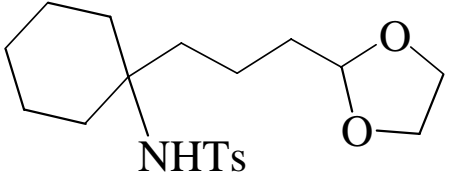

25

A solution of CuBr.DMS (35 mg, $0.17 \mathrm{mmol}, 0.4 \mathrm{eq})$ in DMS (0.5 mL) was added to the Buchi Grignard solution ( $2 \mathrm{~mL}, 0.43 \mathrm{M}, 0.85 \mathrm{mmol}, 2 \mathrm{eq}$ ) at $-78{ }^{\circ} \mathrm{C}$ and stirred for an hour. Then a solution of 24 (113 mg, $0.43 \mathrm{mmol}, 1 \mathrm{eq})$ in THF (0.5 mL) was added at $-78{ }^{\circ} \mathrm{C}$ and stirred for 10 minutes. The solution was left stirring and allowed to warm to room temperature overnight. The reaction was quenched with water and the organic layer was separated. The aqueous layer was re-extracted with ethyl acetate (2 portions), the organic layers were combined and washed with brine. The solution was dried over $\mathrm{MgSO}_{4}$ and concentrated under reduced pressure. The residue was purified by column chromatography (using a continuous gradient from petroleum ether and ending with 5:1 petroleum ether/ethyl acetate) to give 25 as a white solid, $141 \mathrm{mg}$ (90\%).

Mp $109-111{ }^{\circ} \mathrm{C}$

${ }^{1} \mathrm{H}$ NMR (250 MHz, $\left.\mathrm{CDCl}_{3}\right): \delta$ 1.16-1.79 (16H, m), 2.40 (3H, s), 3.78-3.96 (4H, m), 4.38 (1H, s), 4.68 (1H, t, J=5.0 Hz), 7.28 (2H, d, $J=8.5$ Hz), 7.78 (2H, d, $J=8.5$ Hz).

${ }^{13} \mathrm{C}$ NMR (100.6 MHz, $\left.\mathrm{CDCl}_{3}\right): \delta 17.5,21.4,21.5,25.3,33.7,35.9,38.3,59.7,64.7$, 104.4, 126.9, 129.4, 140.6, 142.7.

FTIR (thin film): 3280 (br), 2935 (m), 2864 (m), 1329 (m), 1152 (s), 1094 (m) cm . m/z (TOF ES): 306, $390\left(\mathrm{MNa}^{+}\right)$, 406. HRMS (TOF ES) calcd. for $\mathrm{C}_{19} \mathrm{H}_{29} \mathrm{NO}_{4} \mathrm{SNa}$ $\left(\mathrm{MNa}^{+}\right)$: 390.1715. Found: 390.1700. 


\section{Synthesis of 1-(toluene-4-sulfonyl)-1-aza-spiro[5.5]undec-2-ene 26}

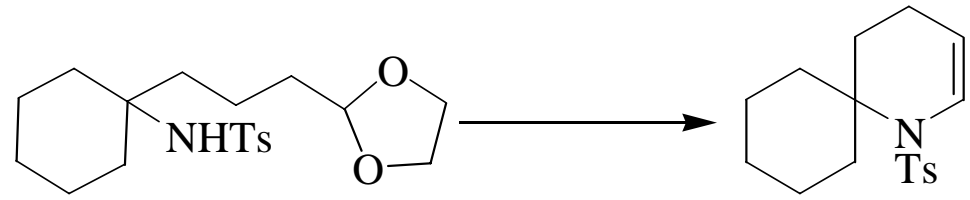

25

A hydrogen chloride solution in ether (1M, $0.3 \mathrm{~mL}, 0.27 \mathrm{~mol}, 2.1 \mathrm{eq})$ was added to a solution of 25 (50 mg, $0.14 \mathrm{mmol}, 1 \mathrm{eq}$ ) in acetone $(1.4 \mathrm{~mL})$. The mixture was stirred at room temperature overnight. Reaction was quenched with a saturated solution of $\mathrm{K}_{2} \mathrm{CO}_{3}$ and the product was extracted with ethyl acetate, dried over $\mathrm{MgSO}_{4}$ and concentrated under reduced pressure. The residue was purified by column chromatography (using a continuous gradient from petroleum ether and ending with 19:1 petroleum ether/ethyl acetate) to give 26 as a white solid, $23 \mathrm{mg}$ (54\%).

Mp 119-122 ${ }^{\circ} \mathrm{C}$.

${ }^{1} \mathrm{H}$ NMR (250 MHz, $\left.\mathrm{CDCl}_{3}\right): \delta$ 1.34-1.42 (4H, m), 1.50-1.66 (4H, m), $1.74(2 \mathrm{H}, \mathrm{t}$, $J=6.5 \mathrm{~Hz}$ ), 1.93-2.02 (2H, m), 2.04-2.18 (2H, m), 2.41 (3H, s), 4.96 (1H, dt, $J=4.0 \mathrm{~Hz}$, 8.5 Hz), 6.97 (1H, dt, J=2.0 Hz, 8.5 Hz), 7.23-7.29 (2H, m), 7.69 (2H, d, J=8.5 Hz).

${ }^{13} \mathrm{C}$ NMR (100.6 MHz, $\left.\mathrm{CDCl}_{3}\right): \delta$ 18.6, 21.5, 22.4, 25.2, 28.1, 32.9, 62.3, 105.1, 126.4 (x2), 129.5, 140.9, 142.8 .

FTIR (thin film): 2928 (m), 2864 (w), 1656 (m), 1332 (s), 1252 (m), 1161 (s), 1103 (s) $\mathrm{cm}^{-1}$.

m/z (TOF ES): $306\left(\mathrm{MH}^{+}\right), 328\left(\mathrm{MNa}^{+}\right)$. HRMS (TOF ES) calcd. for $\mathrm{C}_{17} \mathrm{H}_{24} \mathrm{NO}_{2} \mathrm{~S}$ $\left(\mathrm{MH}^{+}\right)$: 306.1528. Found: 306.1521.

Synthesis of N-[4-tert-butyl-1-(3-[1,3]dioxolan-2-yl-propyl)-cyclohexyl]-4-methylbenzenesulfonamide 28

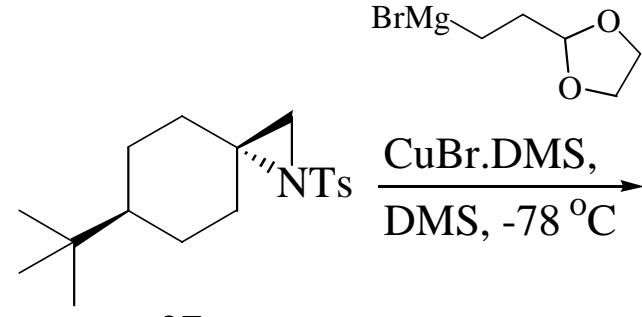

27

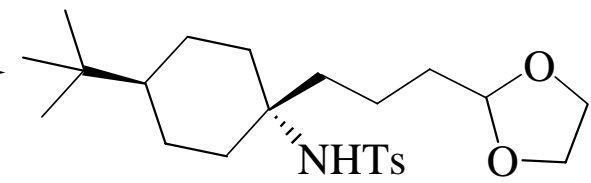

28 
A solution of copper-bromide DMS (45 mg, $0.22 \mathrm{mmol}, 0.4 \mathrm{eq}$ ) in DMS (1 mL) was added to the Buchi Grignard solution ( $4 \mathrm{~mL}, 0.28 \mathrm{M}, 1.12 \mathrm{mmol}, 2 \mathrm{eq}$ ) at $-78{ }^{\circ} \mathrm{C}$ and stirred for an hour. Then a solution of 27 (180 mg, $0.56 \mathrm{mmol}, 1 \mathrm{eq})$ in THF (2 mL) was added at $-78{ }^{\circ} \mathrm{C}$ and stirred for 10 minutes. The solution was left stirring and allowed to warm up to room temperature over night. The reaction was quenched with water and the organic layer was separated. Then extracted with ethyl acetate (2 portions), the organic layers were combined and washed with brine. The solution was dried over $\mathrm{MgSO}_{4}$ and concentrated under reduced pressure. The residue was purified by column chromatography (using a continuous gradient from petroleum ether and ending with 3:1 petroleum ether/ethyl acetate) to give 28 as a white solid, $189 \mathrm{mg}$ (79\%).

Mp $133-134{ }^{\circ} \mathrm{C}$

${ }^{1} \mathrm{H}$ NMR (250 MHz, $\left.\mathrm{CDCl}_{3}\right): \delta$ 0.80-1.10 (2H, m), $0.78(9 \mathrm{H}, \mathrm{s}), 1.18-1.65(11 \mathrm{H}, \mathrm{m})$, 1.75-1.86 (2H, m), 2.41 (3H, s), 3.79-3.99 (4H, m), 4.47 (1H, s), 4.74 (1H, t, J=4.5 $\mathrm{Hz}), 7.28$ (2H, d, $J=8.5 \mathrm{~Hz}), 7.77$ (2H, d, $J=8.5 \mathrm{~Hz}$ ).

${ }^{13} \mathrm{C}$ NMR (62.9 MHz, $\left.\mathrm{CDCl}_{3}\right): \delta 17.3,21.5,23.0,27.5,32.2,33.3,33.7,36.2,47.0$, 59.9, 64.8, 104.5, 126.9, 129.4, 141.0, 142.7.

FTIR (thin film): 3273 (br), 2948 (s), 2868 (m), 1331 (m), 1156 (s), 1094 (m), 1032 (w) $\mathrm{cm}^{-1}$.

m/z (TOF ES): $446(\mathrm{MNa}+)$. HRMS (TOF ES) calcd. for $\mathrm{C}_{23} \mathrm{H}_{37} \mathrm{NO}_{4} \mathrm{SNa}\left(\mathrm{MNa}^{+}\right)$: 446.2341. Found: 446.2357.

\section{Synthesis of 9-tert-butyl-1-(toluene-4-sulfonyl)-1-aza-spiro[5.5]undec-2-ene 29}

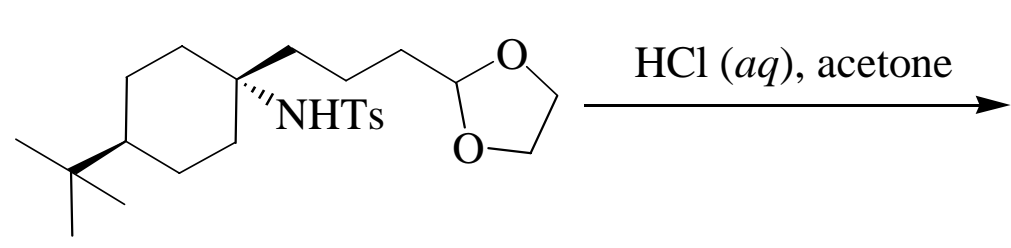

28<smiles>CC(C)(C)C1CCC2(CCC=CN2[AsH])CC1</smiles>

29

An aqueous solution of hydrogen chloride (1M, $1.7 \mathrm{~mL}, 1.7 \mathrm{~mol}, 7.1 \mathrm{eq})$ was added to a solution of 28 (100 mg, $0.24 \mathrm{mmol}, 1 \mathrm{eq})$ in acetone $(2.4 \mathrm{~mL})$. The mixture was stirred at room temperature overnight. Reaction was quenched with a saturated solution of $\mathrm{K}_{2} \mathrm{CO}_{3}(30 \mathrm{~mL})$ and the product was extracted with ethyl acetate, dried 
over $\mathrm{MgSO}_{4}$, filtered and concentrated under reduced pressure. The residue was purified by column chromatography (using a continuous gradient from petroleum ether and ending with 19:1 petroleum ether/ethyl acetate) to give $\mathbf{2 9}$ as a white solid, $69 \mathrm{mg}(83 \%)$.

Mp $139-142{ }^{\circ} \mathrm{C}$

${ }^{1} \mathrm{H}$ NMR (250 MHz, CDCl $): \delta 0.74$ (9H, s), 0.89-1.09 (3H, m), 1.44-1.65 (6H, m), 1.86-1.95 (2H, m), 1.99-2.15 (2H, m), 2.34 (3H, s), 4.83-4.91 (1H, m), 6.86-6.92 (1H, m), 7.20 (2H., d, $J=8.0 \mathrm{~Hz}$ ), 7.62 (2H., d, $J=8.0 \mathrm{~Hz}$ ).

${ }^{13} \mathrm{C}$ NMR (62.9 MHz, $\left.\mathrm{CDCl}_{3}\right): \delta 18.6,21.5,23.1,27.5,28.1,32.2,33.0,46.9,62.1$, 105.0, 126.5 (x2), 129.5, 140.9, 142.8

FTIR (thin film): 2943 (s), 1657 (m), 1325 (m), 1255 (m), 1162 (s), 1098 (s) cm². m/z (TOF ES): $384\left(\mathrm{MNa}^{+}\right)$. HRMS (TOF ES) calc. for $\mathrm{C}_{21} \mathrm{H}_{31} \mathrm{NO}_{2} \mathrm{SNa}\left(\mathrm{MNa}^{+}\right)$: 384.1973. Found: 384.1965.

\section{Synthesis of (S)-2-allyl-6-benzyl-1-(toluene-4-sulfonyl)-piperidine 30}<smiles>[As]N1C=CCCC1Cc1ccccc1</smiles>

11<smiles>C=CCC1CCCC(Cc2ccccc2)N1[As]</smiles>

30

To a solution of 11 (105 mg, $0.322 \mathrm{mmol}, 1 \mathrm{eq})$ in DCM (4 mL) at $-20{ }^{\circ} \mathrm{C}$ was added allyltrimethylsilane (307 $\mu \mathrm{L}, 1.95 \mathrm{mmol}, 6 \mathrm{eq}$ ) and trifluoroacetic acid (99 $\mu \mathrm{L}, 1.29$ mmol, 4 eq). The reaction mixture was stirred at $-20{ }^{\circ} \mathrm{C}$ for $2 \mathrm{~h}$ and was then allowed to warm to room temperature overnight. The reaction was quenched with $\mathrm{NaHCO}_{3}$ and extracted using DCM (3 portions). The combined organic layers were washed with water and brine, dried over $\mathrm{MgSO}_{4}$, filtered and concentrated under reduced pressure. The residue was purified by column chromatography (using a continuous gradient from petroleum ether and ending with 19:1 petroleum ether/ethyl acetate) to give $\mathbf{3 0}$ as a colourless solid, $101 \mathrm{mg}$ (85\%).

Mp 106-108 ${ }^{\circ} \mathrm{C}$.

$[\alpha]^{25}+50\left(\right.$ c $\left.1.0 \mathrm{~g} / \mathrm{mL}, \mathrm{CH}_{2} \mathrm{Cl}_{2}\right)$. 
${ }^{1} \mathrm{H}$ NMR (250 MHz, $\mathrm{C}_{6} \mathrm{D}_{6}$ ): $\delta$ 0.68-1.45 (6H, m), 1.88 (3H, s), 2.19-2.35 (1H, m), 2.61 (1H, dt, $J=13.5,6.0 \mathrm{~Hz}$ ), 2.78 (1H, dd, $J=12.5,12.0 \mathrm{~Hz}), 3.23$ (1H, dd, $J=13.0,3.0$ $\mathrm{Hz})$, 3.95-4.20 (1H, m), 4.24-4.36 (1H, m), 5.00-5.11 (2H, m), 5.77-5.95 (1H, m), $6.74(2 \mathrm{H}, \mathrm{d}, J=8.0 \mathrm{~Hz}), 7.02-7.29(5 \mathrm{H}, \mathrm{m}), 7.71(2 \mathrm{H}, \mathrm{d}, J=8.0 \mathrm{~Hz})$.

${ }^{13} \mathrm{C}$ NMR (62.9 MHz, $\left.\mathrm{CDCl}_{3}\right): \delta 13.3,21.5,24.8,26.3,40.1,41.8,52.0,54.5,117.4$, 126.4, 126.7, 128.5, 129.4, 129.6, 134.8, 135.8, 139.5, 142.8.

FTIR (thin film): 3063 (m), 3027 (m), 2940 (s), 2859 (s), 1951 (w), 1917 (w), 1303 (s), 1287 (m), 1220 (m), 1161 (s), 1102 (s), 1046 (m) cm ${ }^{-1}$. HRMS (TOF ES) calcd. for $\mathrm{C}_{22} \mathrm{H}_{28} \mathrm{NO}_{4} \mathrm{~S}\left(\mathrm{MH}^{+}\right)$: 370.1841. Found: 370.1849 .

\section{Synthesis of acetic acid 2-acetoxy-6-benzyl-1-(toluene-4-sulfonyl)-piperidin-3-yl ester 31

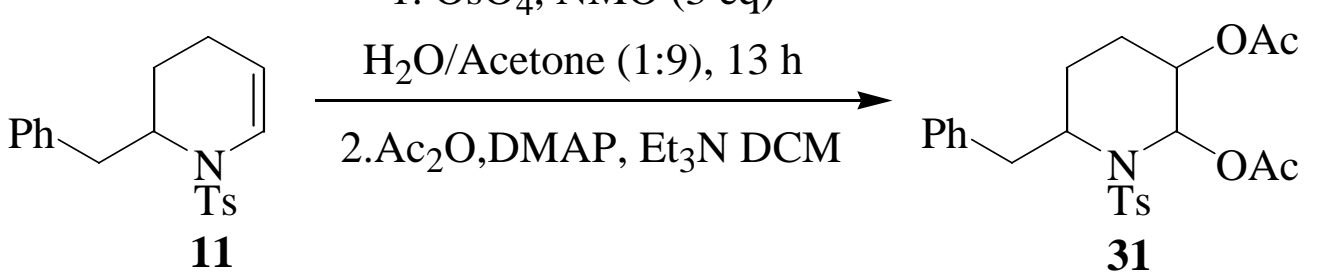

To a solution of 11 (200 mg, $0.61 \mathrm{mmol}$, eq) in acetone (5.5 mL) was added NMO (215 mg, $1.83 \mathrm{mmol}, 3 \mathrm{eq})$ and water $(0.6 \mathrm{~mL})$, followed by osmium tetroxide (2 crystals) and the reaction mixture was stirred at room temperature for 13 hours. The reaction was quenched with sodium metabisulfite with ice cooling, water was added the product was extracted with diethyl ether (3 portions). The combined organic layers were washed with brine and dried over $\mathrm{MgSO}_{4}$, filtered and concentrated under reduced pressure.

To a solution of crude diol in DCM (5 mL) at room temperature was added acetic anhydride (288 $\mu \mathrm{L}$, 3.05 mmol, 5 eq), $\mathrm{Et}_{3} \mathrm{~N}$ (425 $\mu \mathrm{L}$, 3.05mmol, 5 eq), followed by DMAP (8 mg, $0.06 \mathrm{mmol}, 0.1 \mathrm{eq}$ ). After $1 \mathrm{~h}$ the reaction mixture was diluted with water and extracted with DCM (3 portions). The combined organic layers were dried over $\mathrm{MgSO}_{4}$, filtered and concentrated under reduced pressure. The residue purified by column chromatography (using a continuous gradient from petroleum ether and ending with 2:1 petroleum ether/diethyl ether) to give a mixture of diastereoisomers of 31 as a white solid $245 \mathrm{mg}$ (90\%). 
${ }^{1} \mathrm{H}$ NMR (250 MHz, $\mathrm{CDCl}_{3}$ ) for Major Diastereoisomer: $\delta$ 0.90-0.80 (1H, m), 1.561.35 (1H, m), 1.61-1.76 (2H, m), 1.99 (3H, s), 2.07 (3H, s), 2.40 (3H, s), 2.92-3.12 (2H, m), 4.07-4.17 (1H, m), $4.74(1 \mathrm{H}, \mathrm{dt}, J=12.0 \mathrm{~Hz}, 4.0 \mathrm{~Hz}), 6.86$ (1H, d, $J=4.0 \mathrm{~Hz})$, 7.15-7.34 (7H, m), $7.76(2 \mathrm{H}, \mathrm{d}, J=8.0 \mathrm{~Hz})$.

${ }^{13} \mathrm{C}$ NMR (62.9 MHz, $\mathrm{CDCl}_{3}$ ) for Major Diastereoisomer: $\delta$ 18.9, 20.8, 21.1, 21.6, 24.2, 39.6, 54.1, 69.7, 75.9, 126.6, 127.2, 128.7, 129.5, 129.9, 137.5, 138.9, 144.0, 169.1, 169.9.

FTIR (thin film): 3480 (br), 3062 (w), 3027 (w), 2955 (m), 2867 (w), 1748 (s), 1599 (w), 1346 (m), $1242(\mathrm{~m}), 1163$ (s), 1097 (m) cm $\mathrm{cm}^{-1}$.

m/z (TOF ES): 326, 386, 426, $468\left(\mathrm{MNa}^{+}\right)$. HRMS (TOF ES) calc. for $\mathrm{C}_{23} \mathrm{H}_{27} \mathrm{NO}_{6} \mathrm{SNa}\left(\mathrm{MNa}^{+}\right)$: 468.1457. Found: 468.1440 .

\section{Synthesis of 2-benzyl-5-bromo-1-(toluene-4-sulfonyl)-1,2,3,4-tetrahydropyridine} 32<smiles>[N]C1CCC=CN1Cc1ccccc1</smiles>

11<smiles>CC(C#N)CC1CCC(Br)=CN1[As]</smiles>

32

To a stirred solution of $11(100 \mathrm{mg}, 0.31 \mathrm{mmol}, 1 \mathrm{eq})$ in DCM $(2.7 \mathrm{~mL})$ at $-78{ }^{\circ} \mathrm{C}$ was added bromine (40 $\mu \mathrm{L}, 0.78 \mathrm{mmol} 2.5 \mathrm{eq})$ in DCM (1 mL) dropwise until an orange colour persisted. Hünig's base ( $59 \mu \mathrm{L}, 0.34 \mathrm{mmol}, 1.1 \mathrm{eq}$ ) was added and the reaction was left to warm to room temperature, then stirred for a further hour. Aqueous $\mathrm{Na}_{2} \mathrm{~S}_{2} \mathrm{O}_{3}$ solution was added to the reaction mixture and the product was extracted with DCM (3 portions). The combined organic layers were washed with brine and dried over $\mathrm{MgSO}_{4}$, filtered and concentrated under reduced pressure. The residue was purified by column chromatography (using a continuous gradient from petroleum ether and ending with 5:1 petroleum ether/ethyl acetate) to give $\mathbf{3 2}$ as a pale yellow solid, $83 \mathrm{mg}$ (66\%).

Mp $127-129{ }^{\circ} \mathrm{C}$

${ }^{1} \mathrm{H}$ NMR (250 MHz, $\left.\mathrm{CDCl}_{3}\right): \delta$ 0.95-1.13 $(1 \mathrm{H}, \mathrm{m}), 1.43-1.59(1 \mathrm{H}, \mathrm{m}), 2.11-2.25(1 \mathrm{H}$, m), 2.44-2.57 (4H, m), 2.65-2.77 (1H, dd, $J=10.0$ Hz, 13.0 Hz), 2.93-3.05 (1H, dd, 
$J=5.0 \mathrm{~Hz}, 13.0 \mathrm{~Hz}), 4.05-4.18(1 \mathrm{H}, \mathrm{m}), 7.04(1 \mathrm{H}, \mathrm{s}), 7.17-7.36(7 \mathrm{H}, \mathrm{m}), 7.69(2 \mathrm{H}, \mathrm{d}$, $J=8.0 \mathrm{~Hz})$.

${ }^{13} \mathrm{C}$ NMR (62.9 MHz, $\left.\mathrm{CDCl}_{3}\right): \delta$ 21.6, 22.8, 27.2, 38.1, 53.4, 104.3, 123.8, 126.8, 127.0, 128.7, 129.3, 129.9, 135.7, 137.4, 143.9

FTIR (thin film): 3061 (w), 3027 (w), 2930 (w), 2877 (w), 1645 (w), 1598 (w), 1362 (m), 1342 (m), 1248 (m), 1167 (s), 1096 (m), 1049 (m) cm ${ }^{-1}$.

m/z (TOF ES): $408\left(\mathrm{MH}^{+}\right), 430\left(\mathrm{MNa}^{+}\right)$. HRMS (TOF ES) calc. for $\mathrm{C}_{19} \mathrm{H}_{20} \mathrm{NO}_{2} \mathrm{SBr}$ $\left(\mathrm{MH}^{+}\right)$: 406.0476. Found: 406.0493.

\section{Synthesis of (R)-2-allyl-6-methyl-1-(toluene-4-sulfonyl)-piperidine 33}<smiles>C[C@H]1CCC=CN1[AsH3]</smiles>

ent-15

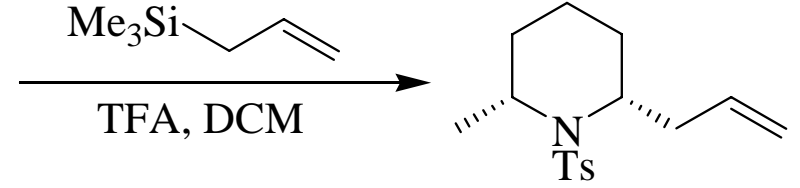

33

To a solution of ent-15 (586 mg, $2.33 \mathrm{mmol}, 1 \mathrm{eq})$ in DCM (44 mL) at $-20{ }^{\circ} \mathrm{C}$ was added allyltrimethylsilane (2.2 mL, $13.99 \mathrm{mmol}, 6 \mathrm{eq})$ and TFA (719 $\mu \mathrm{L}, 9.33 \mathrm{mmol}$, $4 \mathrm{eq}$ ). The reaction mixture was stirred at $-20{ }^{\circ} \mathrm{C}$ for $2 \mathrm{~h}$ and was then allowed to warm to room temperature overnight. The reaction was quenched with $\mathrm{NaHCO}_{3}$ and extracted using DCM (3 portions). The combined organic layers were washed with water and brine, dried over $\mathrm{MgSO}_{4}$, filtered and concentrated under reduced pressure. The residue was purified by column chromatography (using a continuous gradient from petroleum ether and ending with 19:1 petroleum ether/ethyl acetate) to give 33 as a white solid, $571 \mathrm{mg}(83 \%)$.

Mp 66-70 ${ }^{\circ} \mathrm{C}$

$[\alpha]^{25}+32\left(c 0.010 \mathrm{~g} / \mathrm{mL}, \mathrm{CH}_{2} \mathrm{Cl}_{2}\right)$.

${ }^{1} \mathrm{H}$ NMR (250 MHz, $\left.\mathrm{CDCl}_{3}\right): \delta$ 1.11-1.45 (7H, m), 1.51-1.77 (2H, m), 2.31-2.57 (5H, m), 3.96-4.22 (2H, m), 4.99-5.13 (2H, m), 5.69-5.88 (1H, m), 7.27 (2H, d, J=8.0 Hz), $7.71(2 \mathrm{H}, \mathrm{d}, J=8.0 \mathrm{~Hz})$.

${ }^{13} \mathrm{C}$ NMR (62.9 MHz, $\mathrm{CDCl}_{3}$ ): $\delta$ 13.4, 21.5, 21.9, 26.2, 29.4, 40.1, 47.9, 52.1, 117.2, 126.7, 129.5, 136.0, 138.9, 142.6.

FTIR (thin film): 2939 (m), 2361 (m), 1332 (m), 1221 (w), 1165 (s), 1105 (m) cm². 
m/z (TOF ES): $294\left(\mathrm{MH}^{+}\right)$. HRMS (TOF ES) calc. for $\mathrm{C}_{16} \mathrm{H}_{24} \mathrm{NO}_{2} \mathrm{~S}\left(\mathrm{MH}^{+}\right)$: 294.1528. Found: 294.1535.

\section{Synthesis of 2-methyl-6-propyl-1-(toluene-4-sulfonyl)-piperidine $34^{3}$}
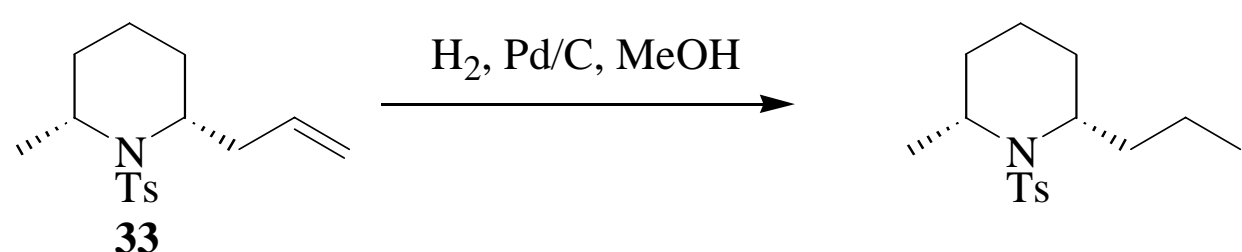

To a solution of 33 (67 mg, $0.17 \mathrm{mmol})$ in methanol (2.3 mL) was added palladium on $10 \%$ carbon (16 mg) and the mixture was stirred under an atmosphere of Hydrogen for 2 h. The reaction mixture was filtered over hyflo supercel and washed with methanol. The solvent from the filtrate was removed under reduced pressure. The residue was then filtered again over hyflo supercel and washed with DCM. The solvent was removed from the filtrate under reduced pressure and gave $\mathbf{3 4}$ as a clear oil, $50 \mathrm{mg}(100 \%)$

$[\alpha]^{25}+20\left(c 0.010 \mathrm{~g} / \mathrm{mL}, \mathrm{CH}_{2} \mathrm{Cl}_{2}\right)$.

${ }^{1} \mathrm{H}$ NMR (250 MHz, CDCl $): \delta 0.94$ (3H, t, $J=7.0 \mathrm{~Hz}$ ), 1.16-1.81 (13H, m), $2.42(3 \mathrm{H}$, s), 3.94-4.19 (2H, m), 7.29 (2H, d, $J=8.0 \mathrm{~Hz}), 7.73(2 \mathrm{H}, \mathrm{d}, J=8.0 \mathrm{~Hz})$.

${ }^{13} \mathrm{C}$ NMR (62.9 MHz, $\left.\mathrm{CDCl}_{3}\right): \delta 13.7,14.0,20.5,21.5,21.8,27.3,29.3,37.8,48.0$, $52.5,126.7,129.5,139.0,124.5$.

FTIR (thin film): 2938 (m), 2872 (m), 1598 (w), 1331 (m), 1286 (m), 1167 (s), 1099 (s) $\mathrm{cm}^{-1}$.

m/z (TOF ES):296 $\left(\mathrm{MH}^{+}\right), 318\left(\mathrm{MNa}^{+}\right)$. HRMS (TOF ES) calc. for $\mathrm{C}_{16} \mathrm{H}_{26} \mathrm{NO}_{2} \mathrm{~S}$ : 296.1684. Found: 296.1683.

\footnotetext{
${ }^{3}$ Lu, Z., Zhou, W., J. Chem. Soc. Perkin. Trans. 1, 1993, 593
} 
(R)-N-(1-Benzyl-4-[1,3]dioxolan-2-yl-butyl)-4-methyl-benzenesulfonamide 9

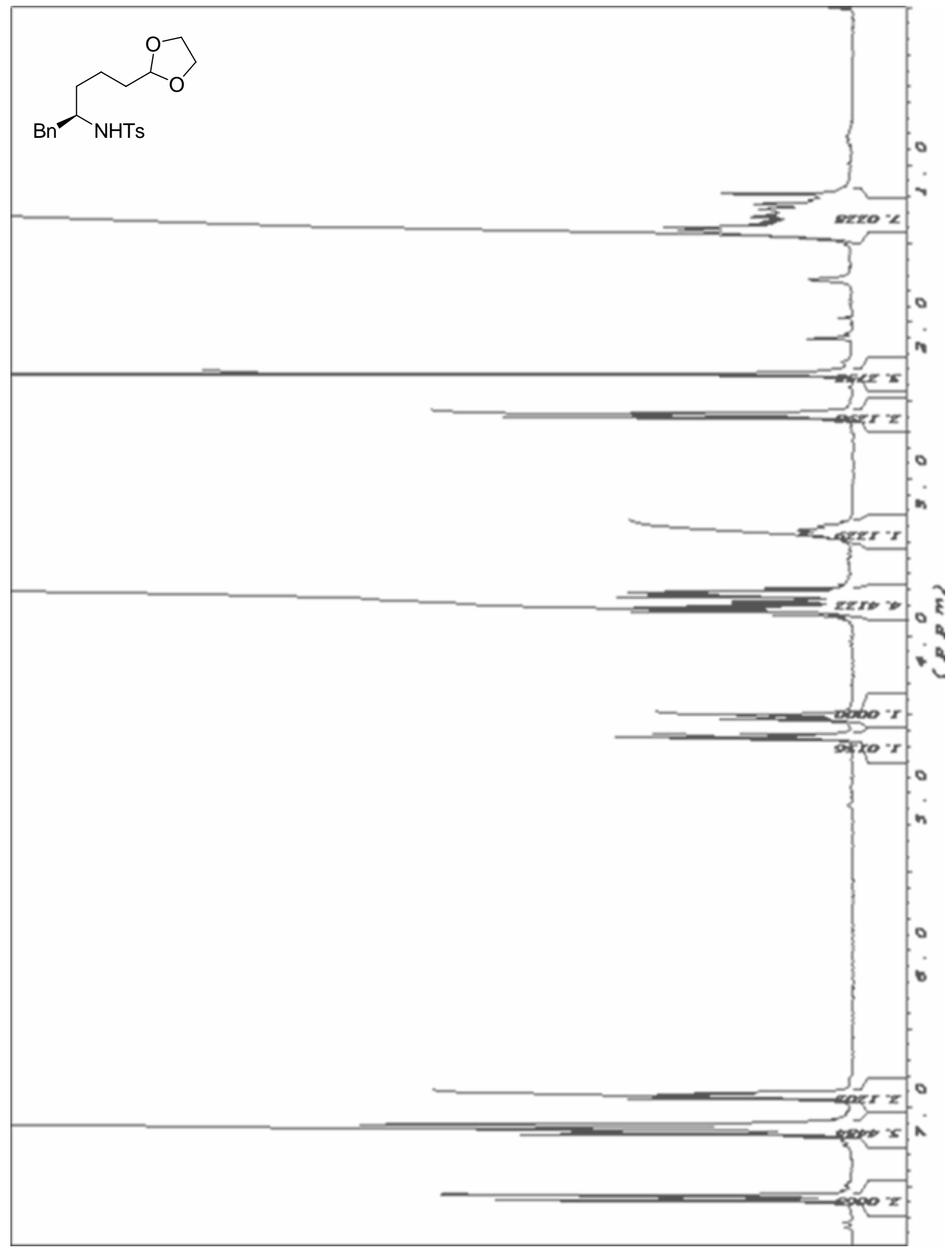




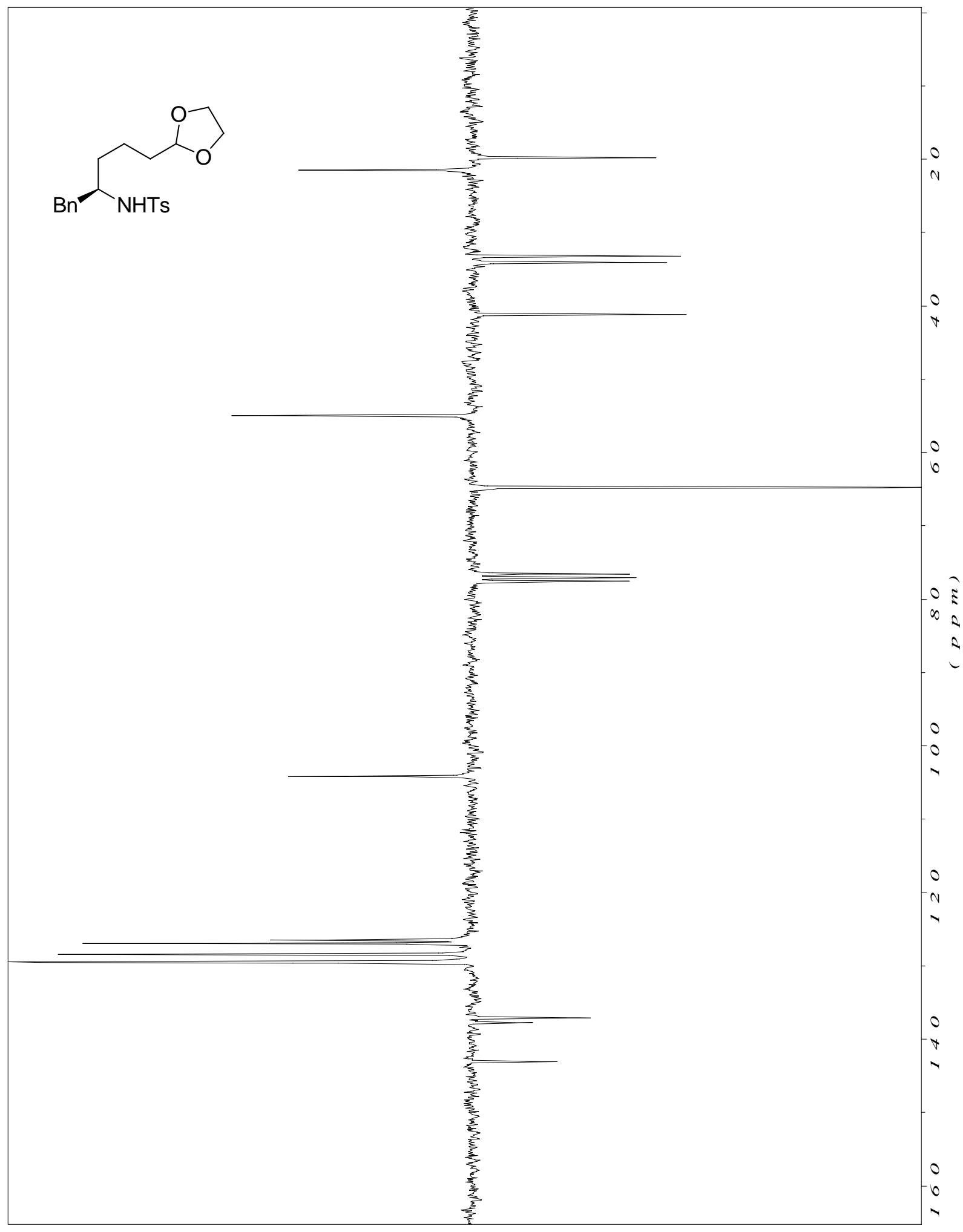


(R)-2-Benzyl-1-(toluene-4-sulfonyl)- 1,2,3,4-tetrahydropyridine 11

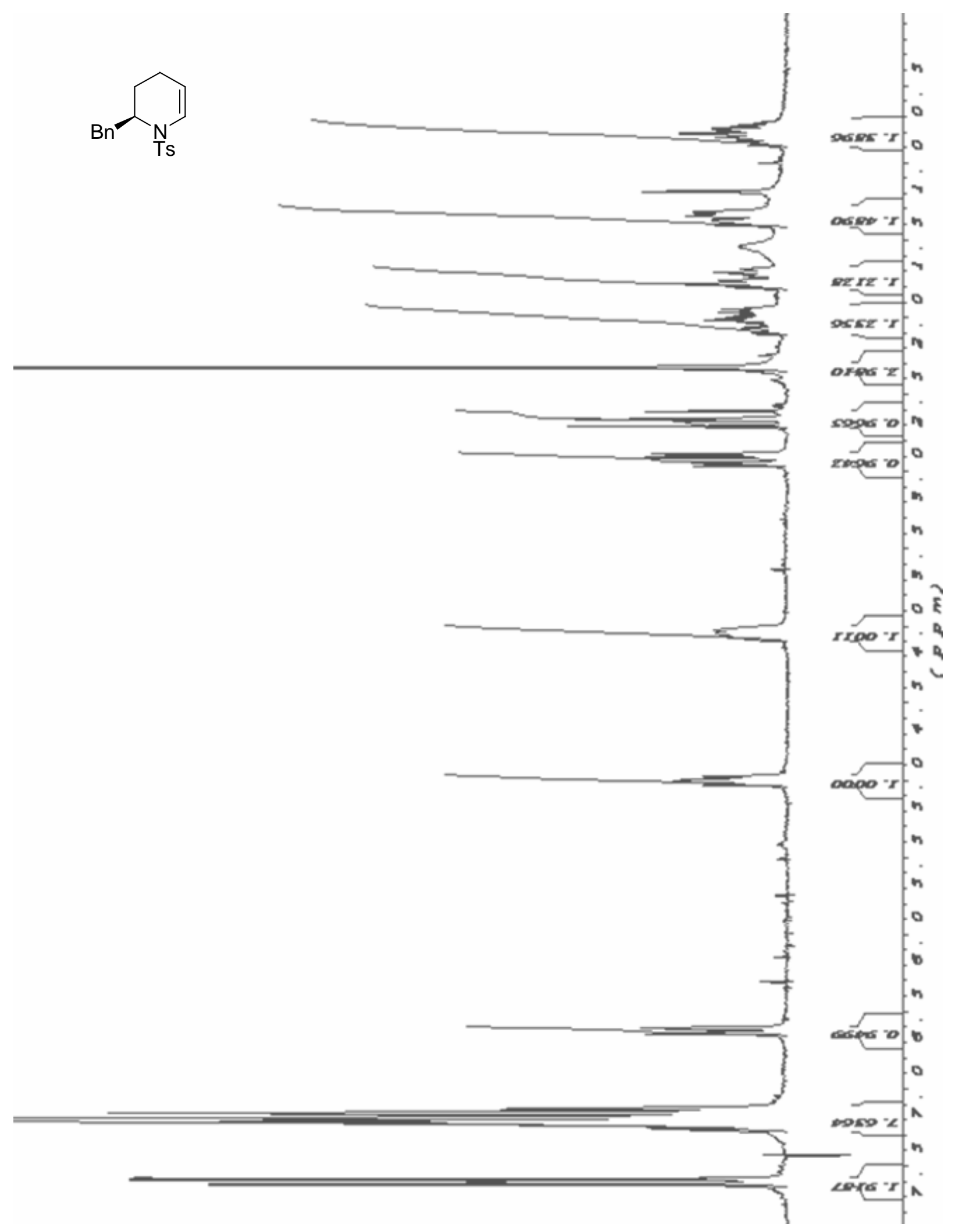




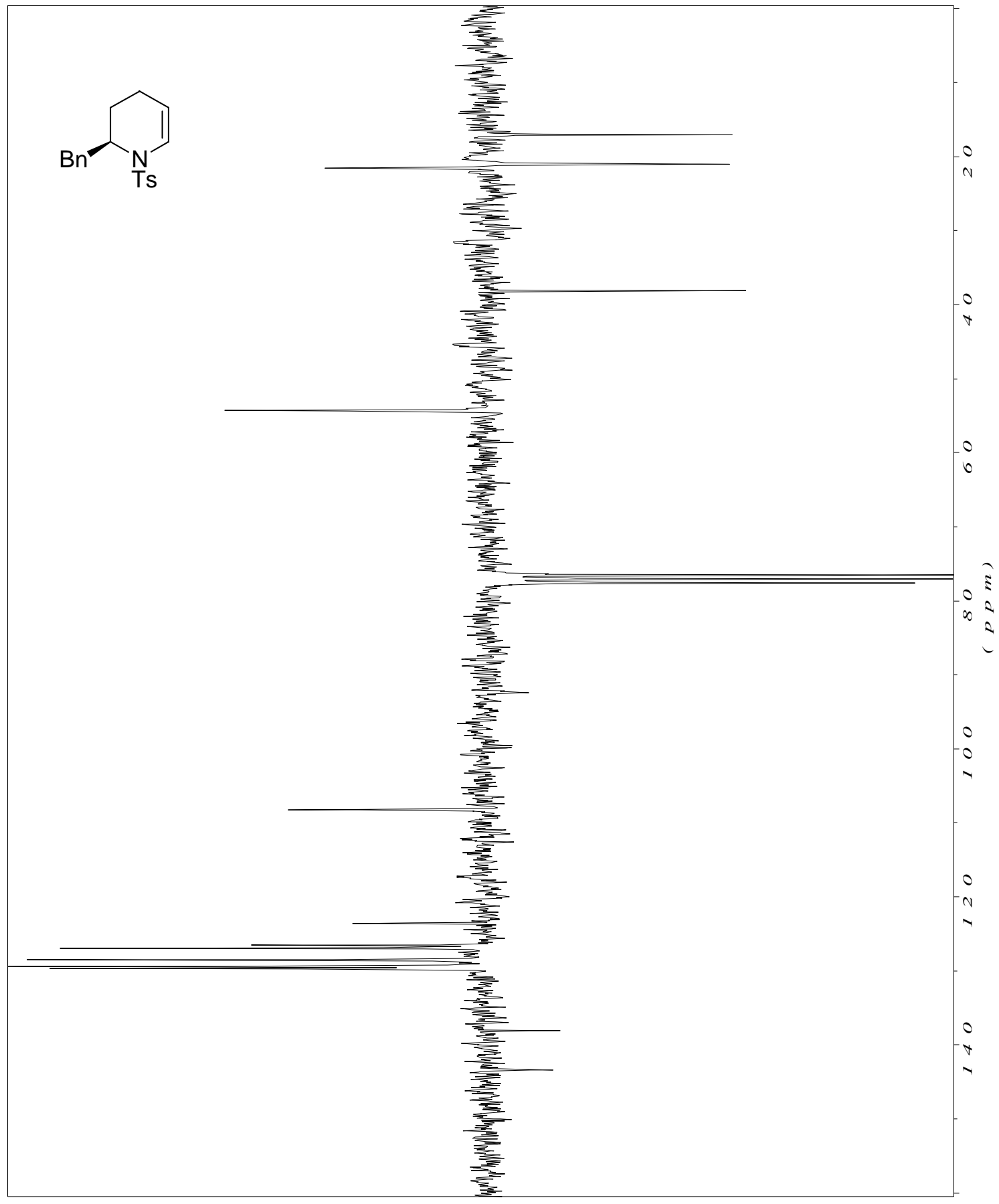


(S)-N-(4-[1,3]dioxolan-2-yl-1-methyl-butyl)-4-methyl-benzenesulfonamide 13

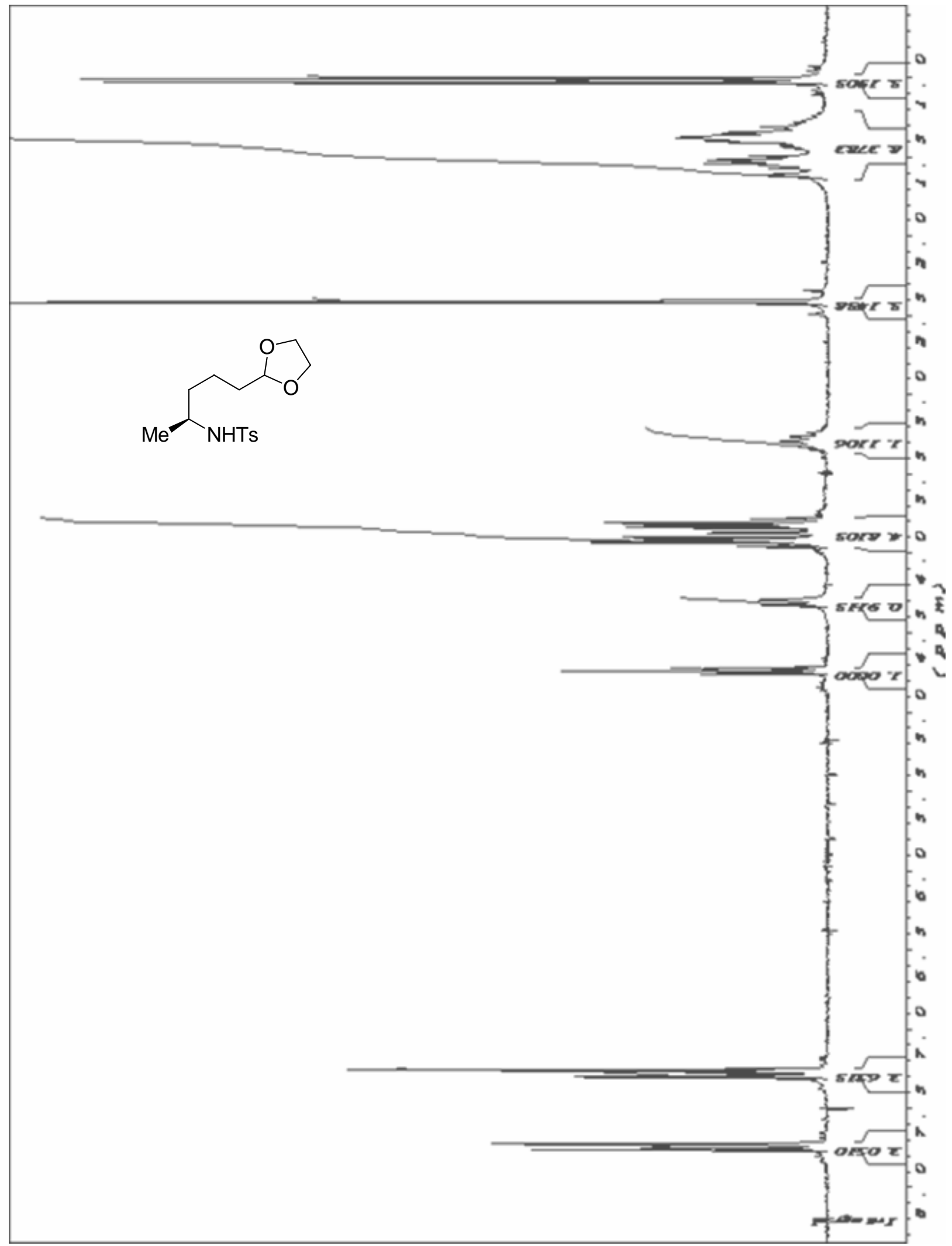




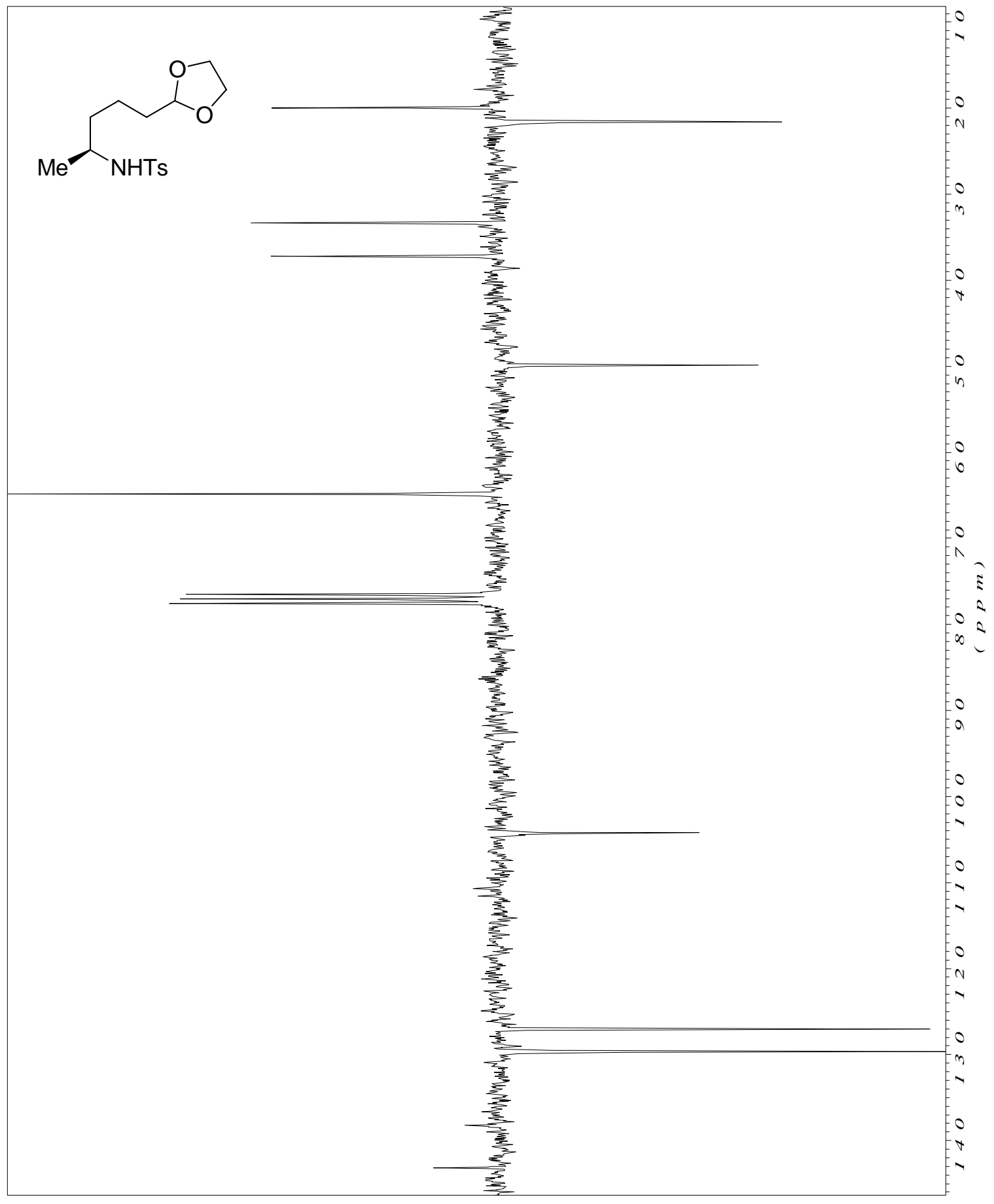


(S)-2-methyl-1-(toluene-4-sulfonyl)-1,2,3,4-tetrahydropyridine 14

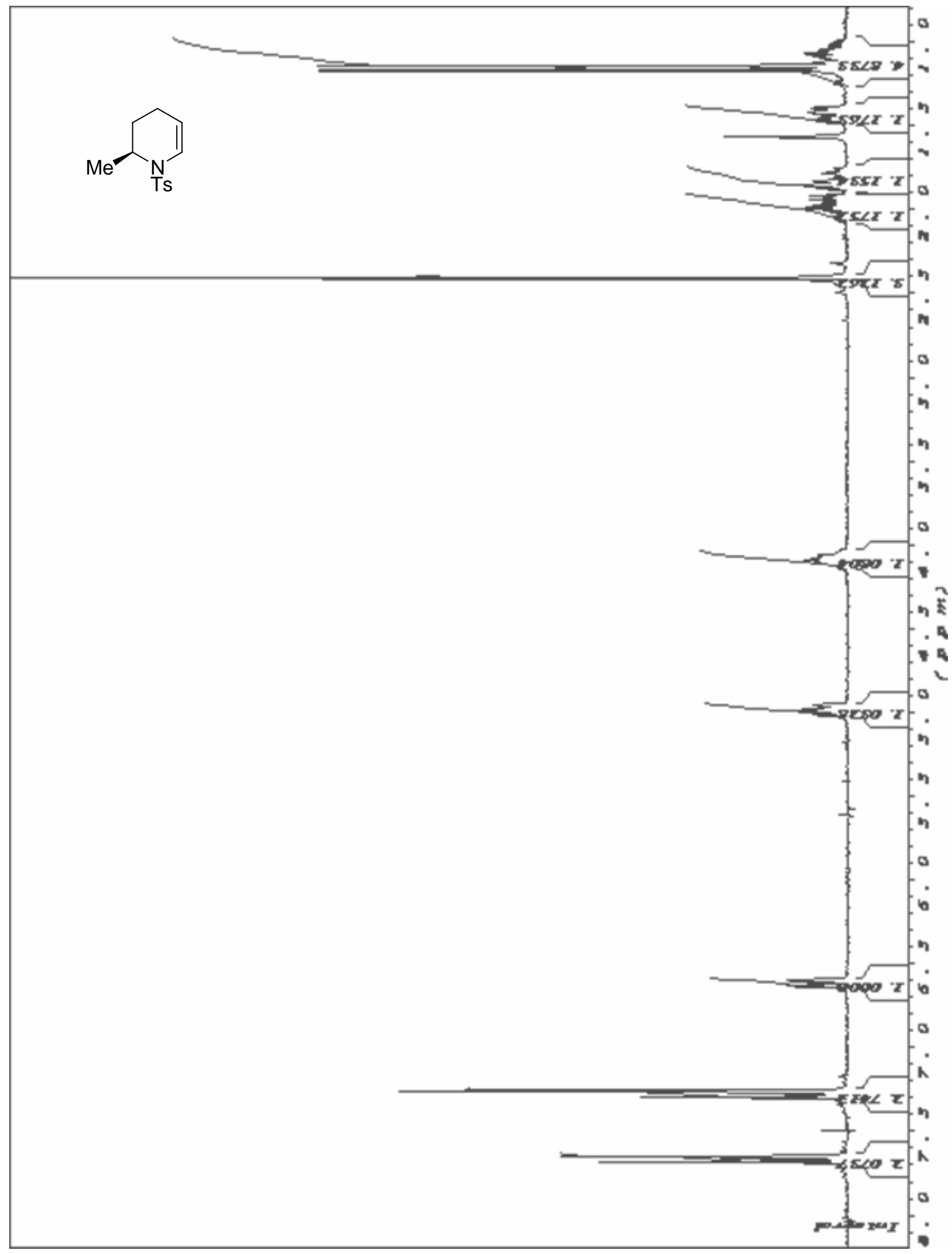




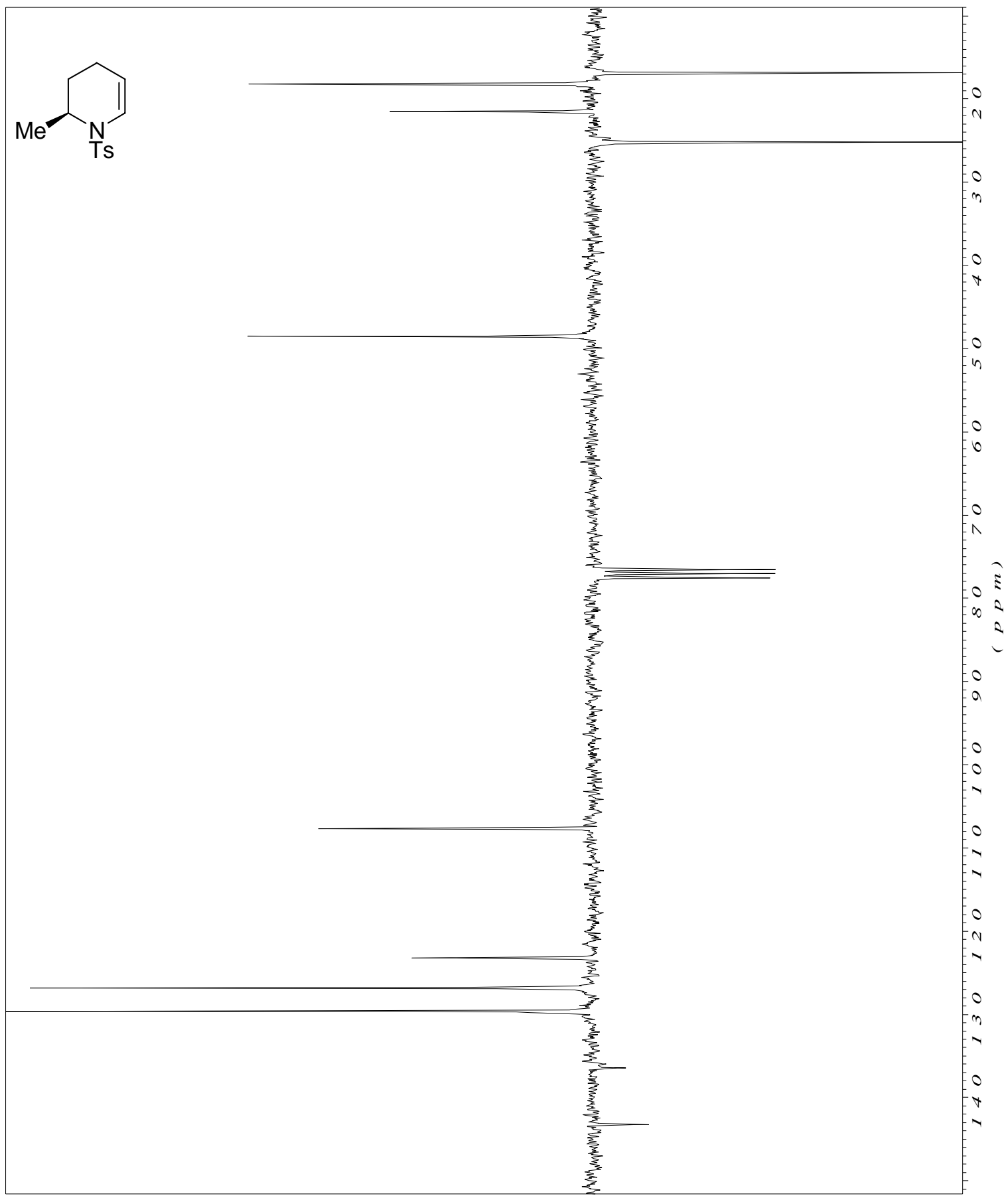


$\mathrm{N}$-(4-[1,3]dioxolan-2-yl-1-isopropyl-butyl)-4-methyl-benzenesulfonamide 16

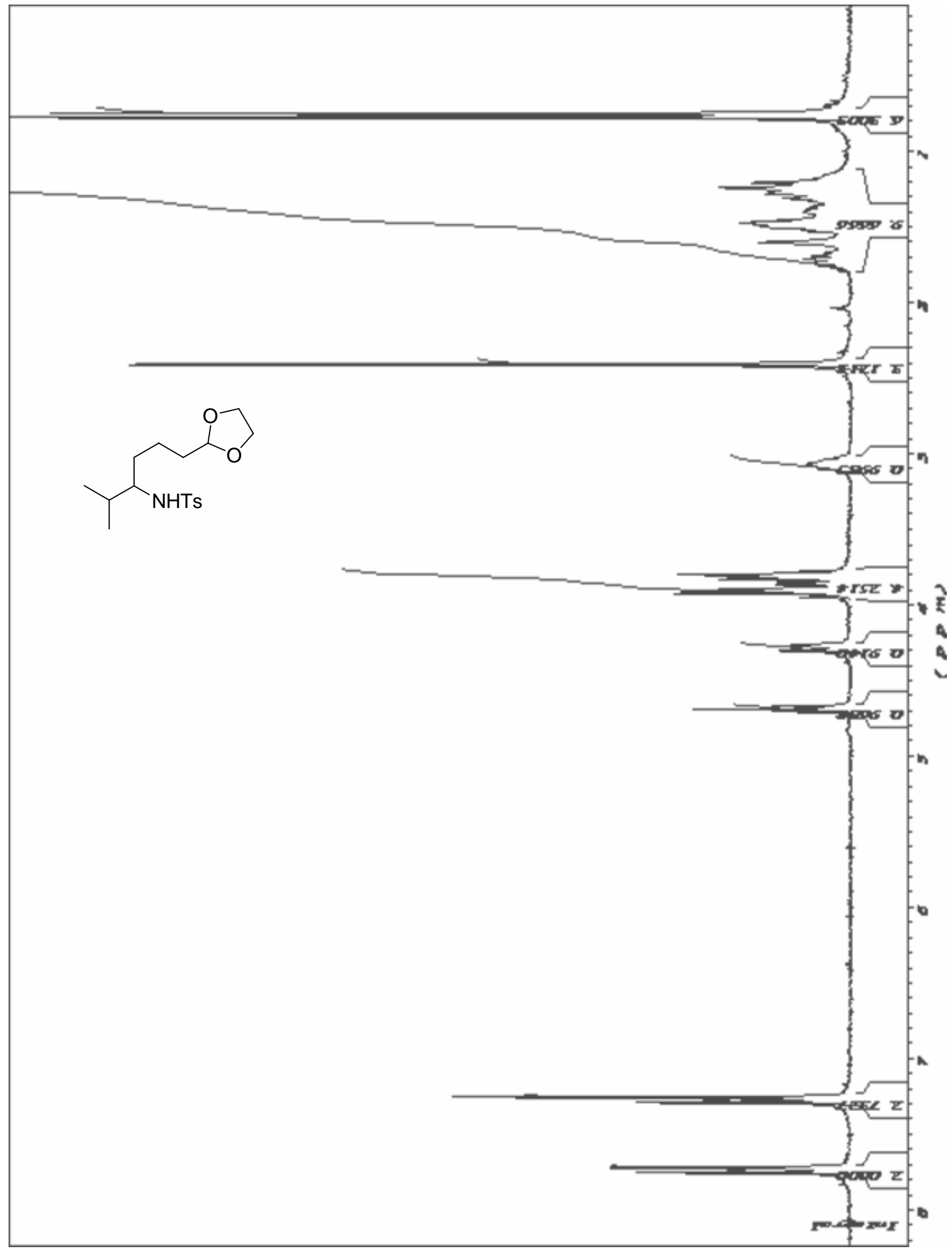




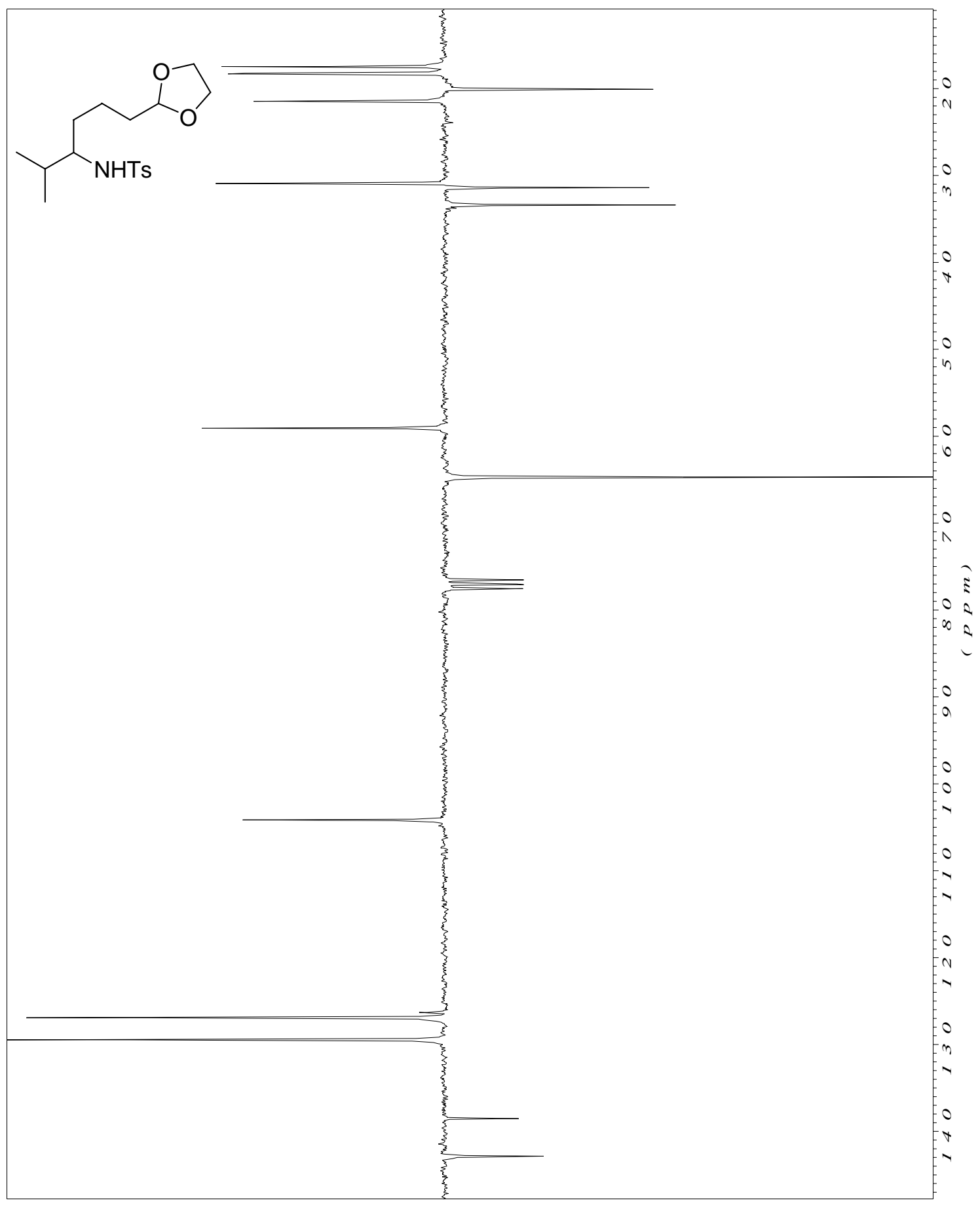


2-isopropyl-1-(toluene-4-sulfonyl)-1,2,3,4-tetrahydropyridine 17

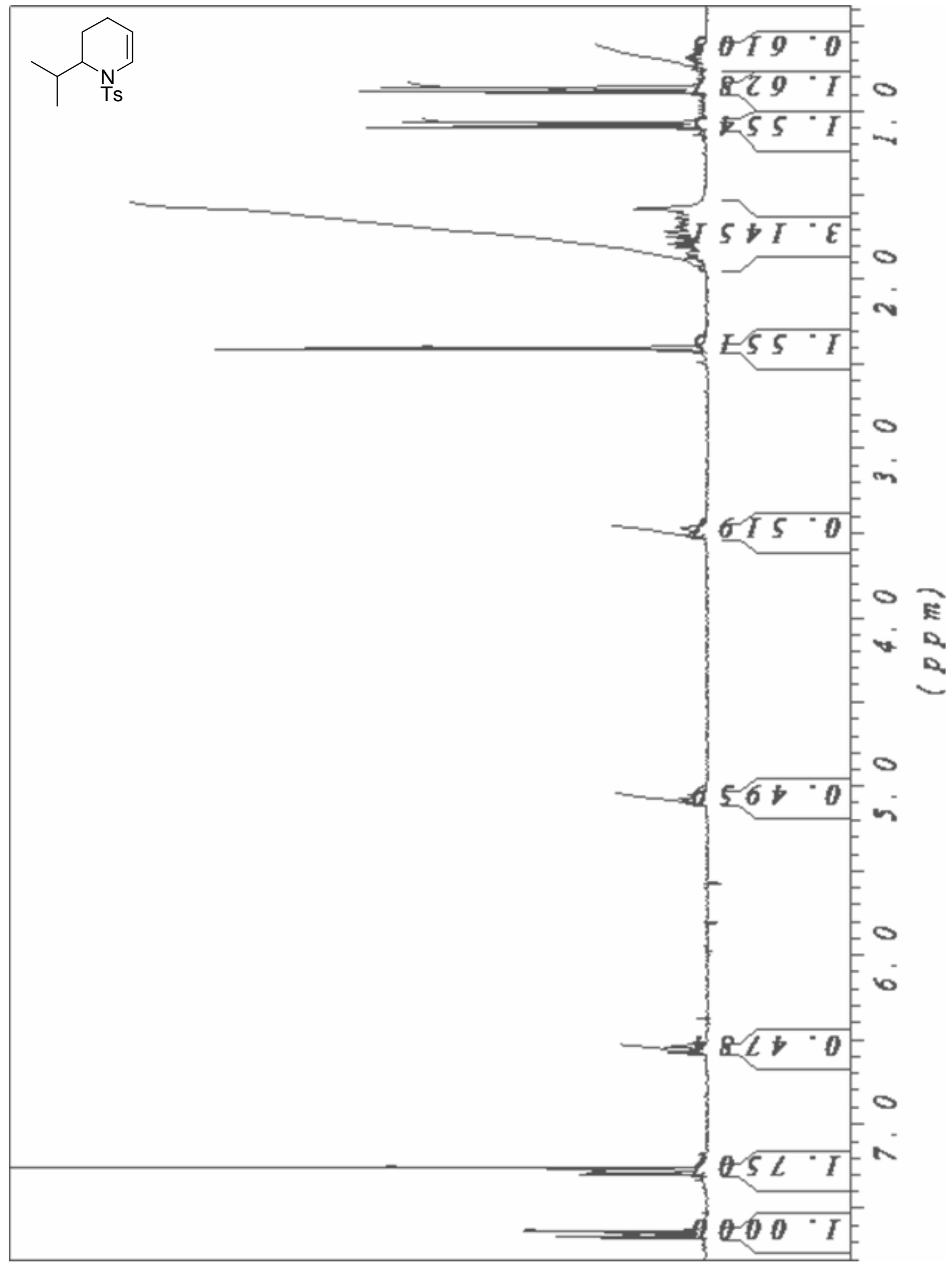




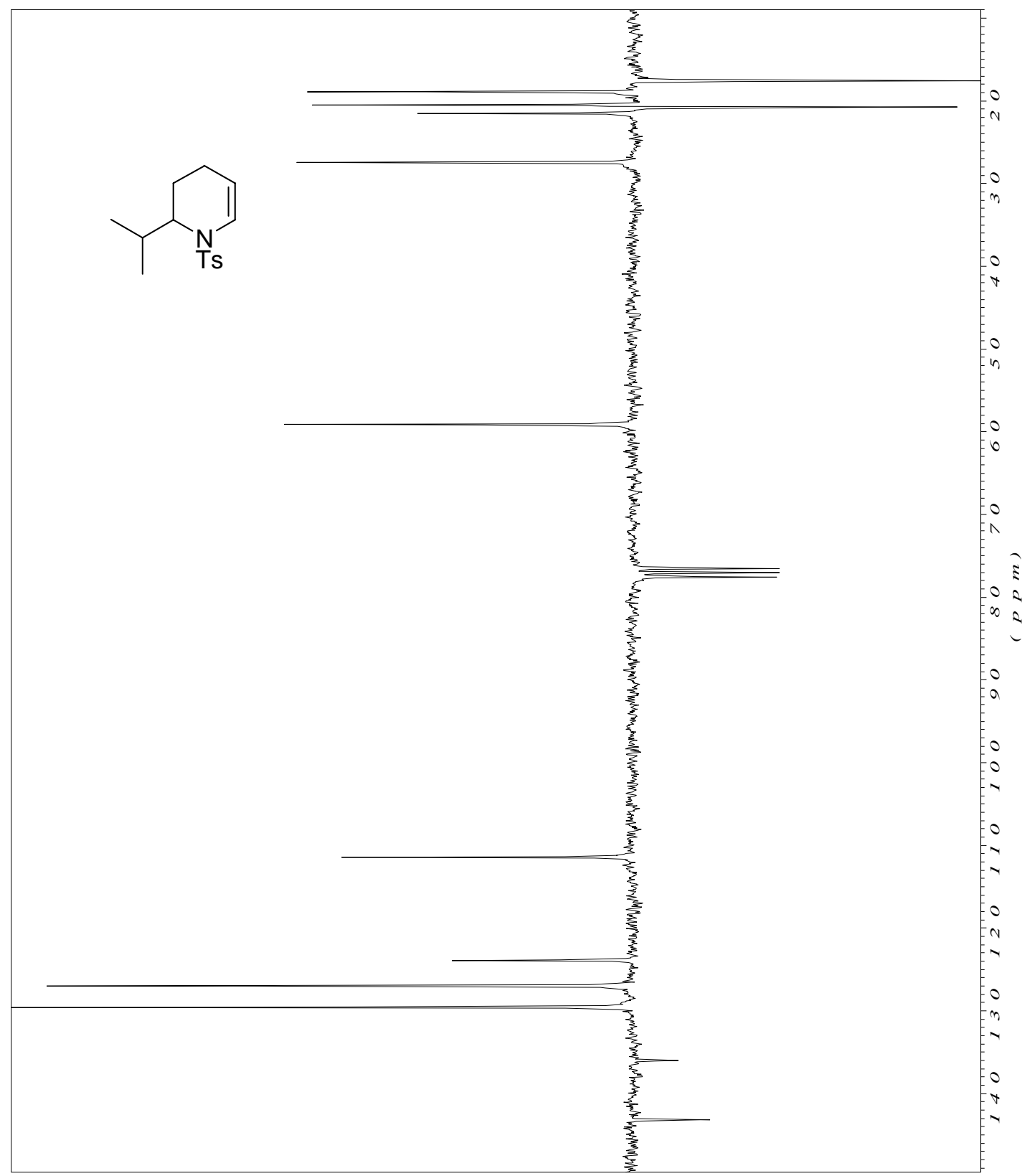


(S)-2-trimethylsilanyl-ethanesulfonic acid (4-[1,3]dioxolan-2-yl-1-methyl-butyl)amide 19

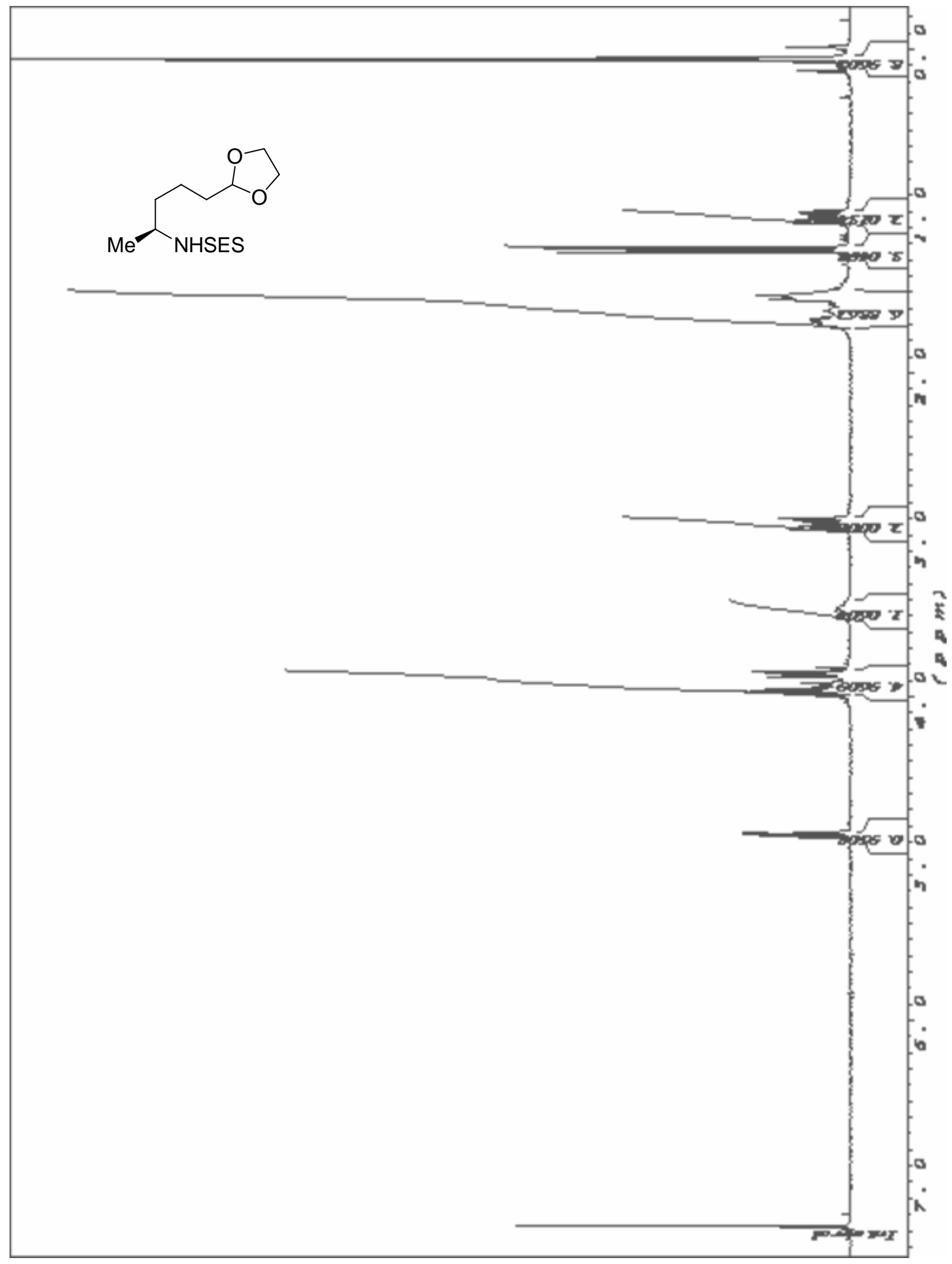




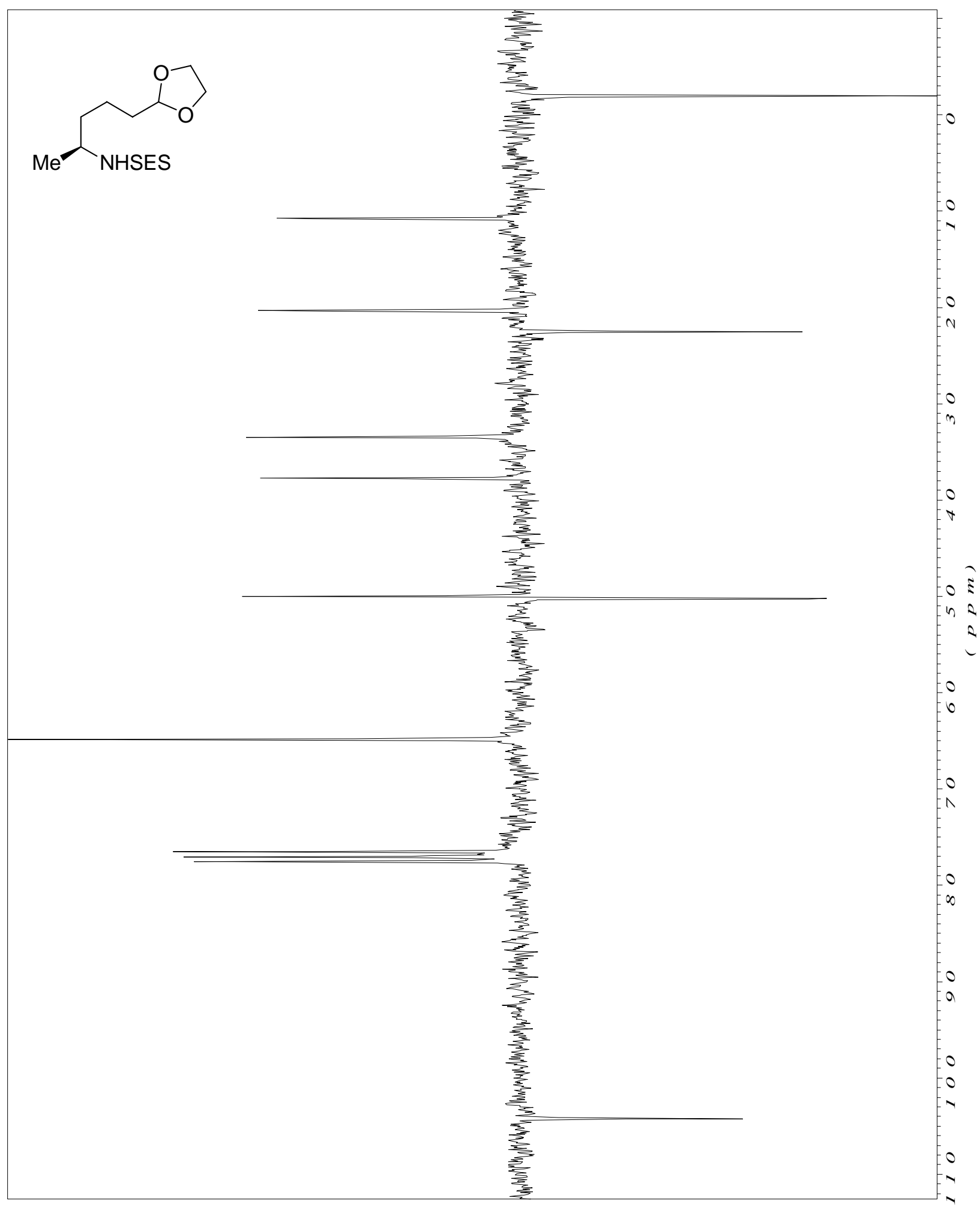


(S)-2-methyl-1-(2-trimethylsilanyl-ethanesulfonyl)-1,2,3,4-tetrahydropyridine 20

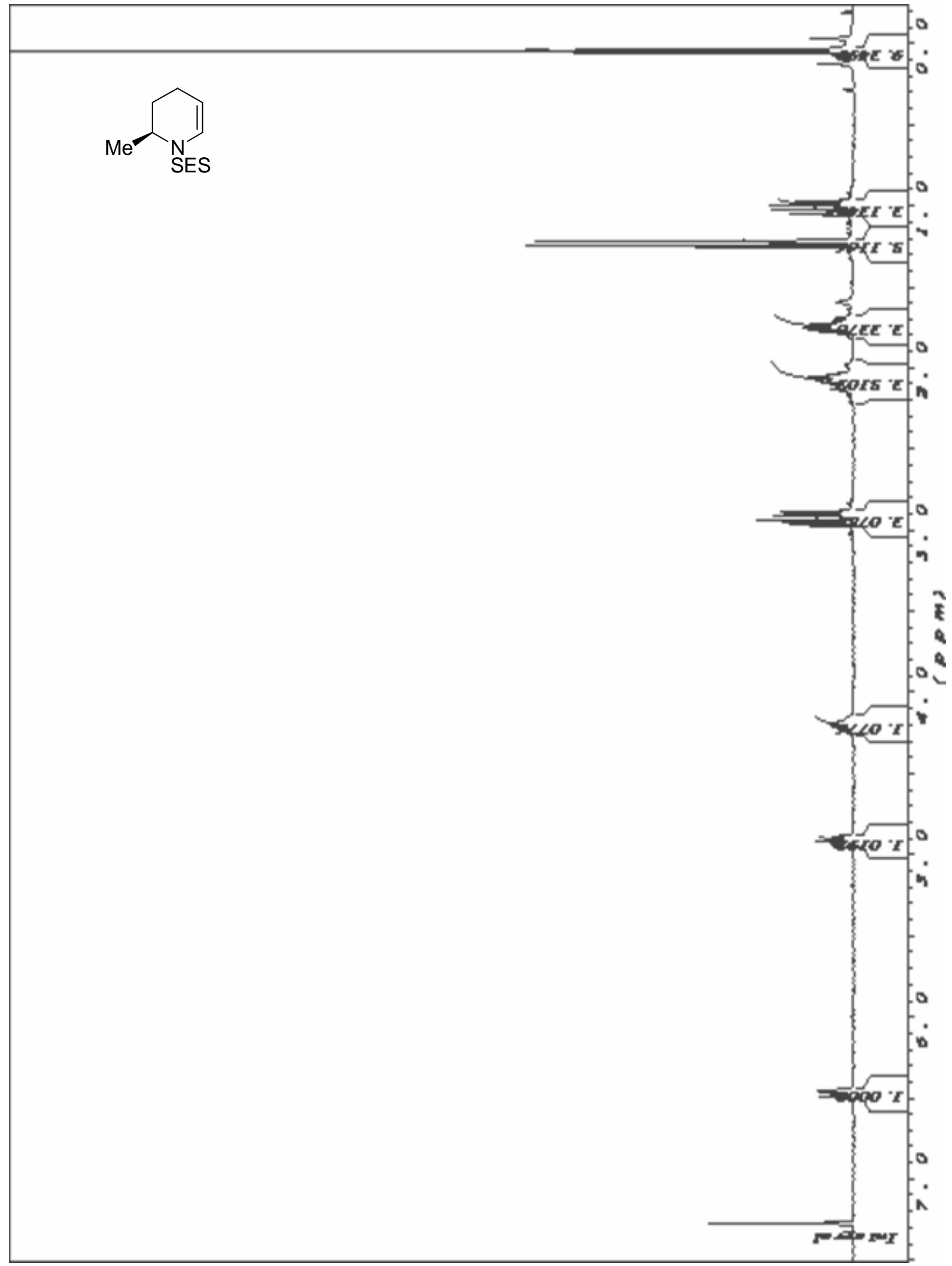




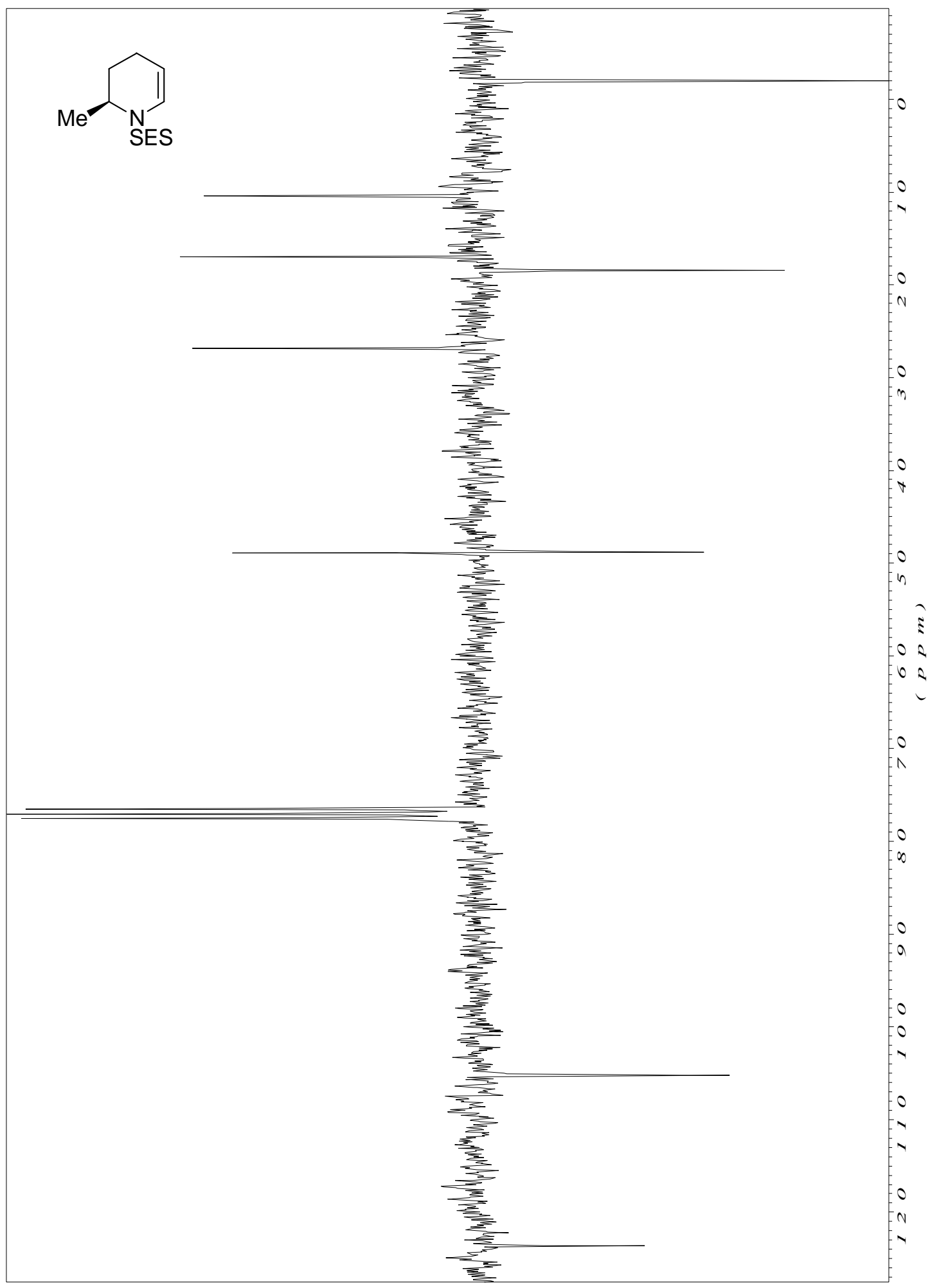


N-[2-(2-[1,3]dioxolan-2-yl-ethyl)-cyclohexyl]-4-methyl-benzenesulfonamide 22

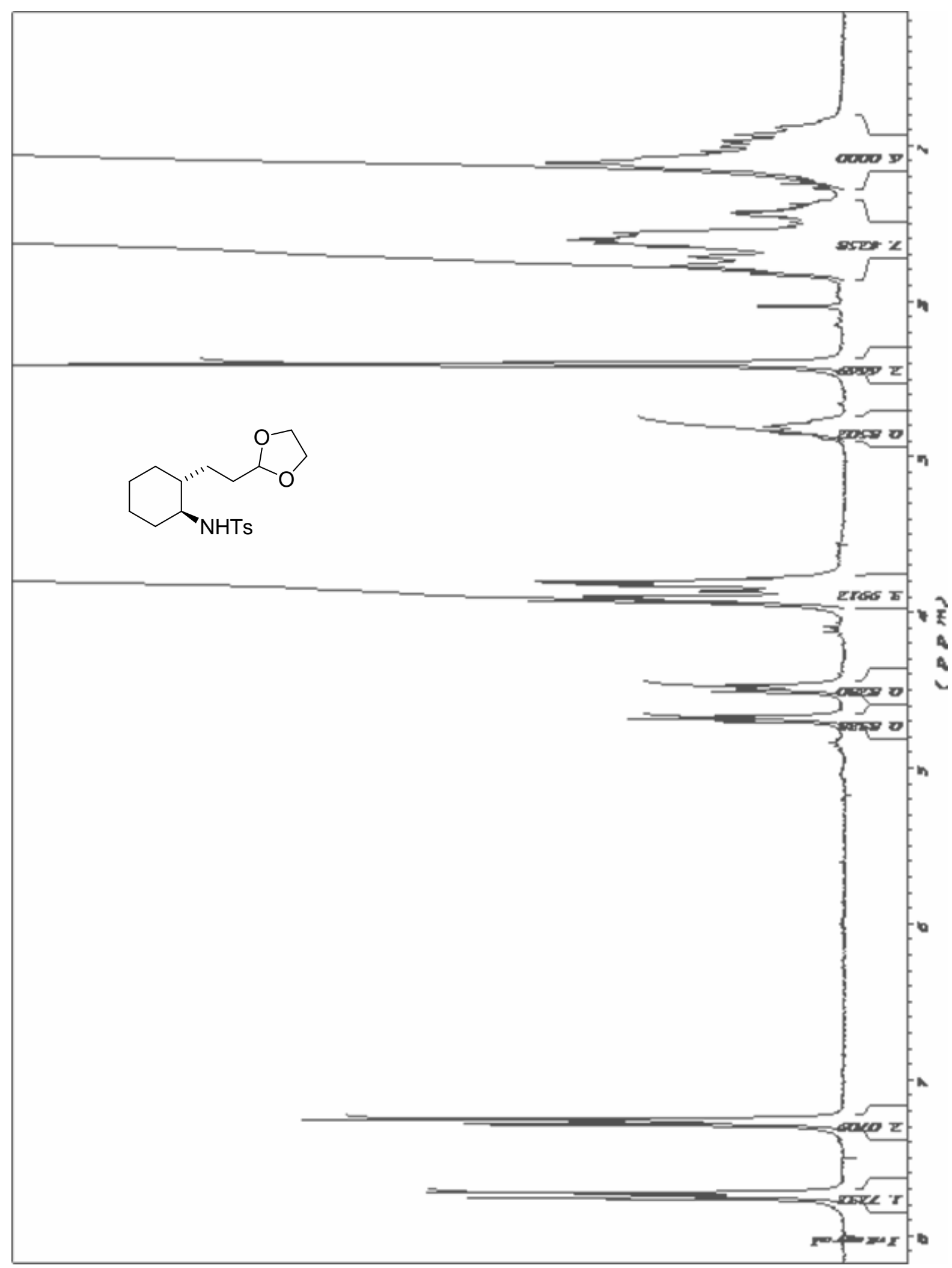




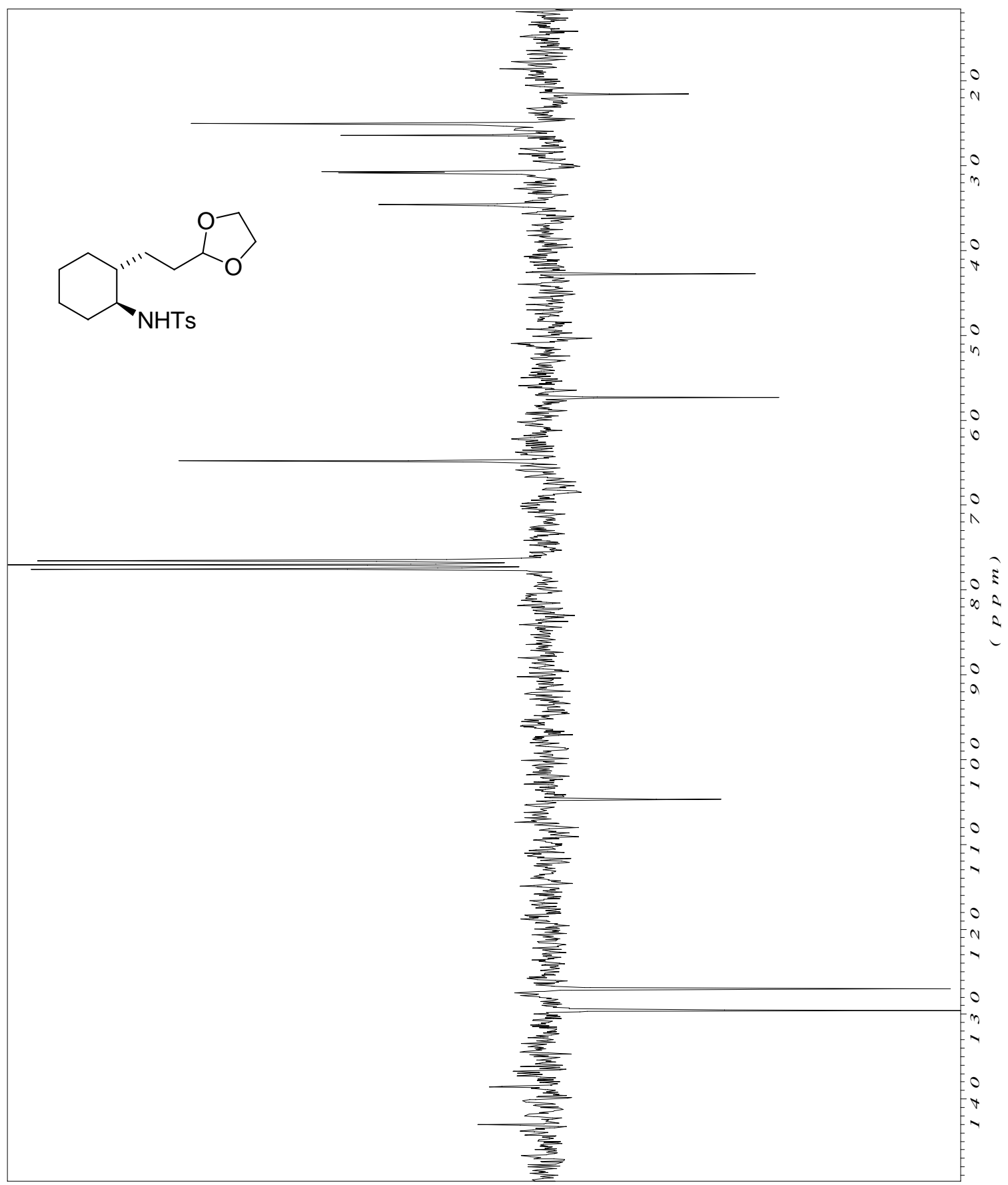


1-(toluene-4-sulfonyl)-1,4,4a,5,6,7,8,8a-octahydroquinoline 23

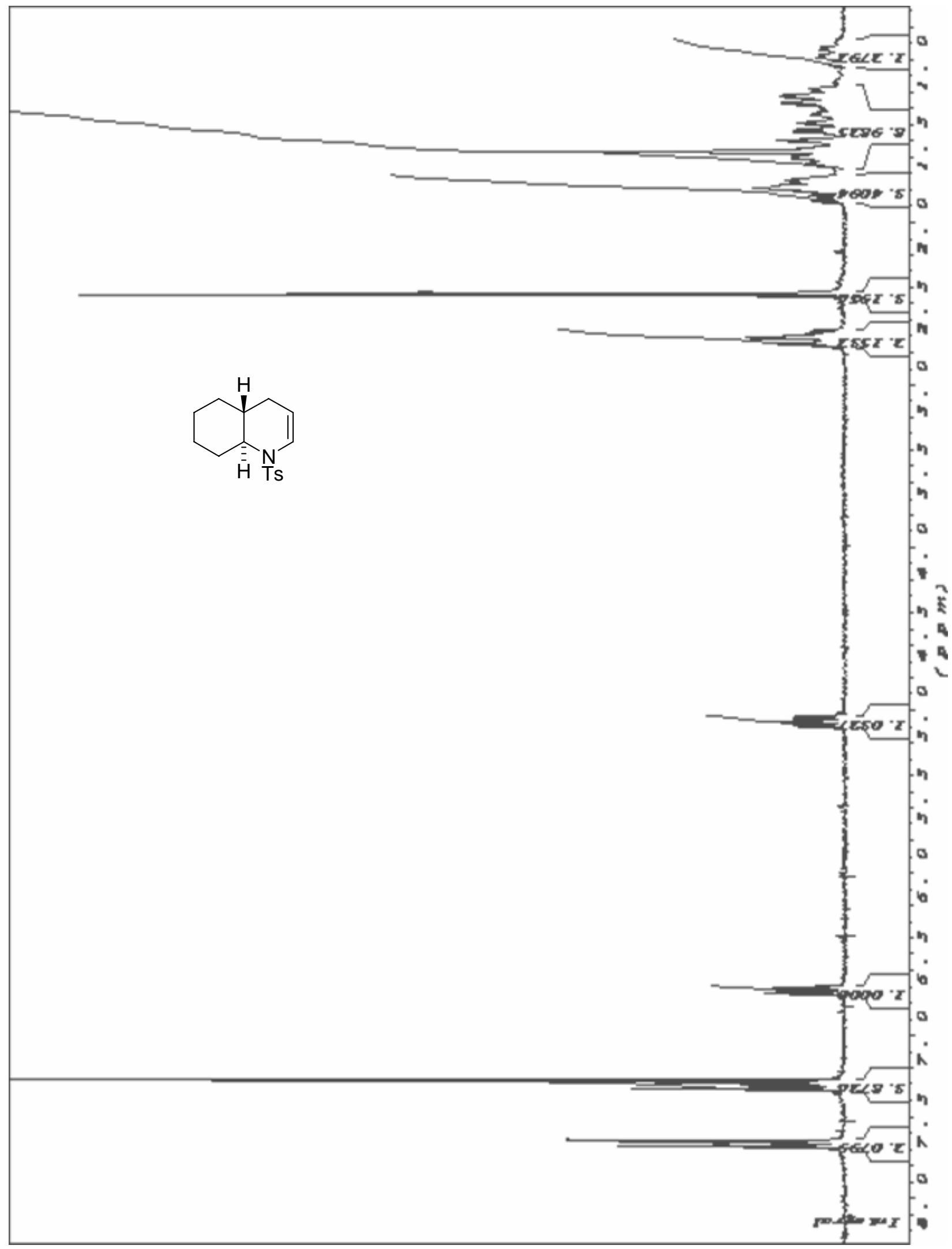




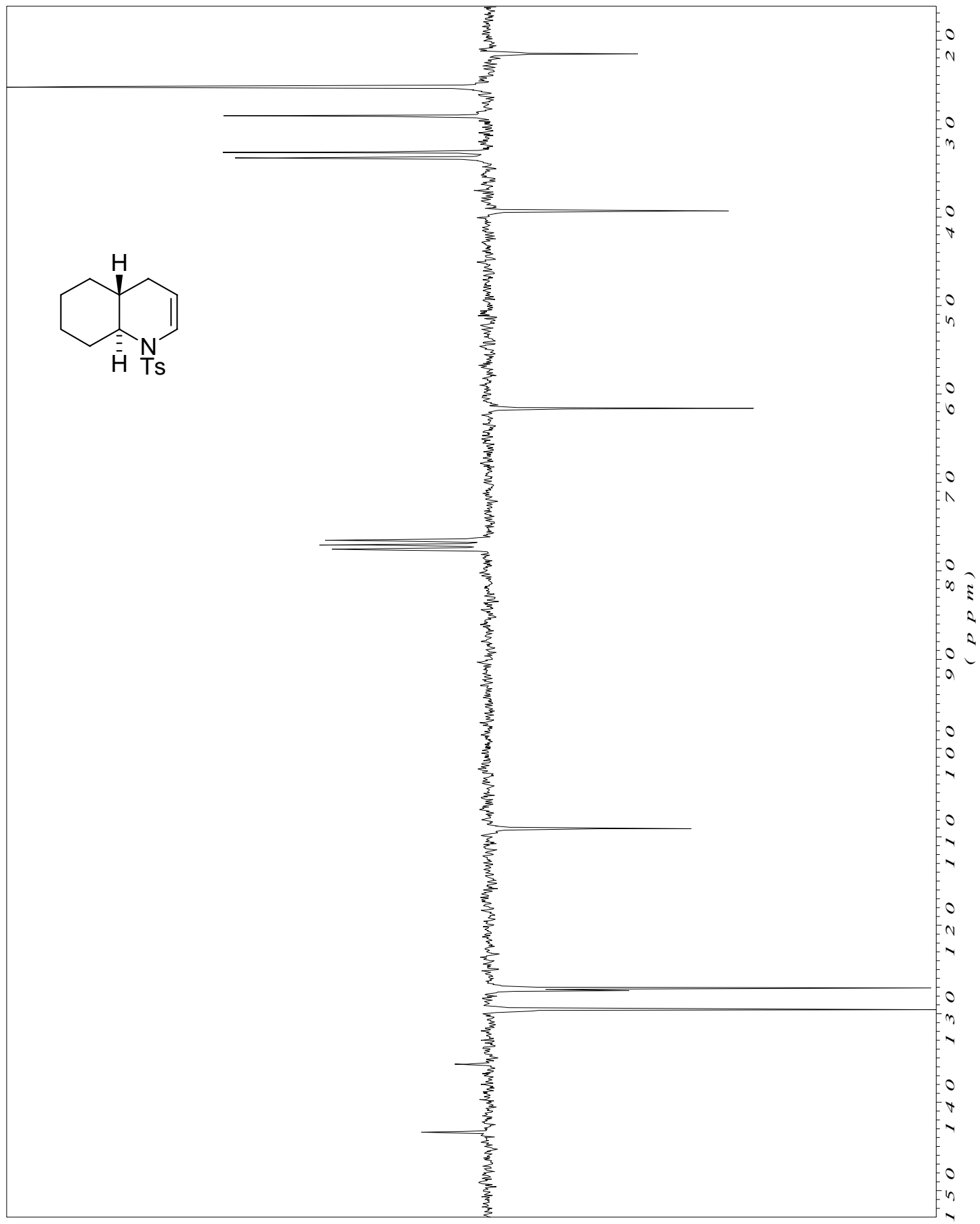


N-[1-(3-[1,3]dioxolan-2-yl-propyl)-cyclohexyl] -4-methyl-benzenesulfonamide 25

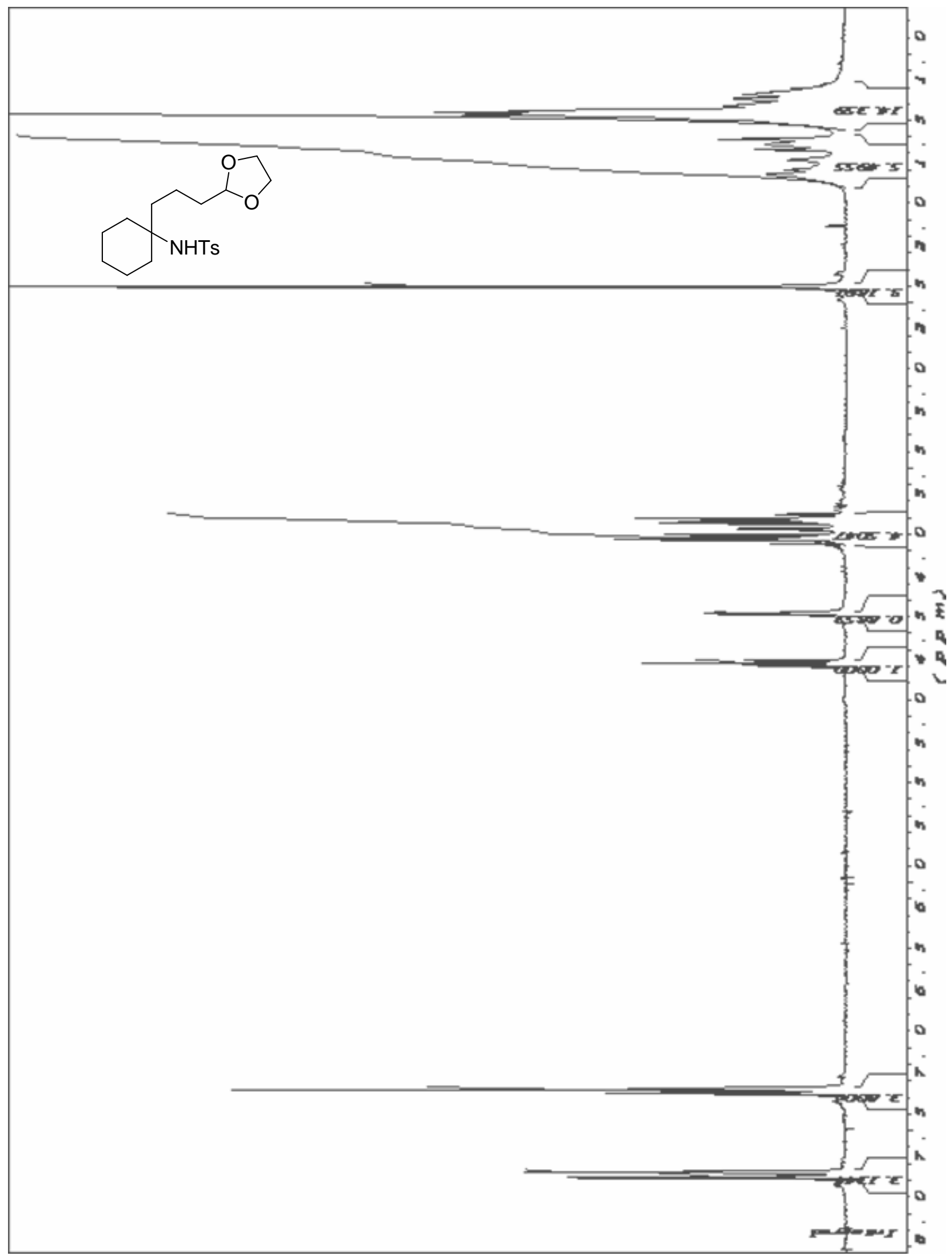




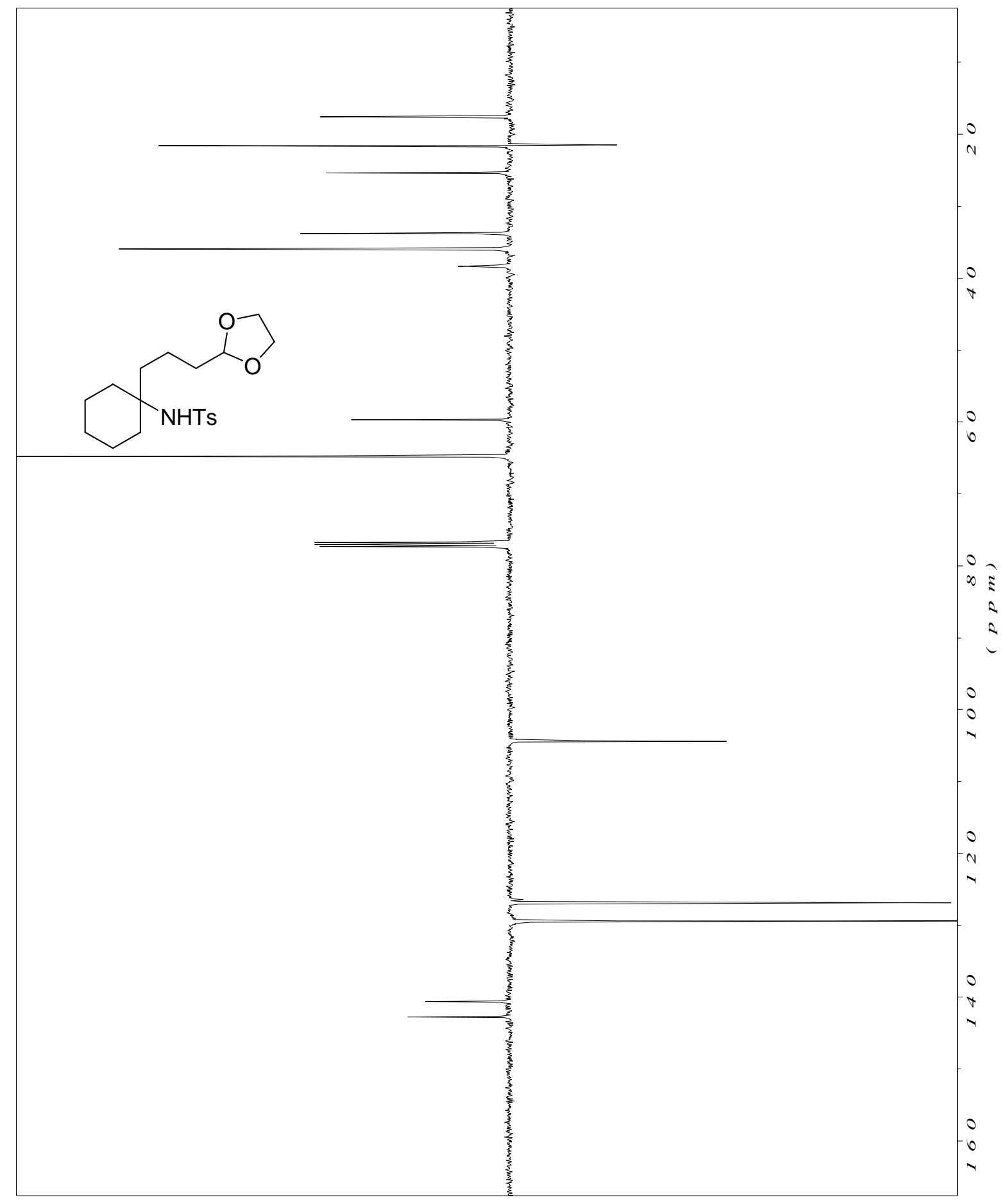


1-(toluene-4-sulfonyl)-1-aza-spiro[5.5] undec-2-ene 26

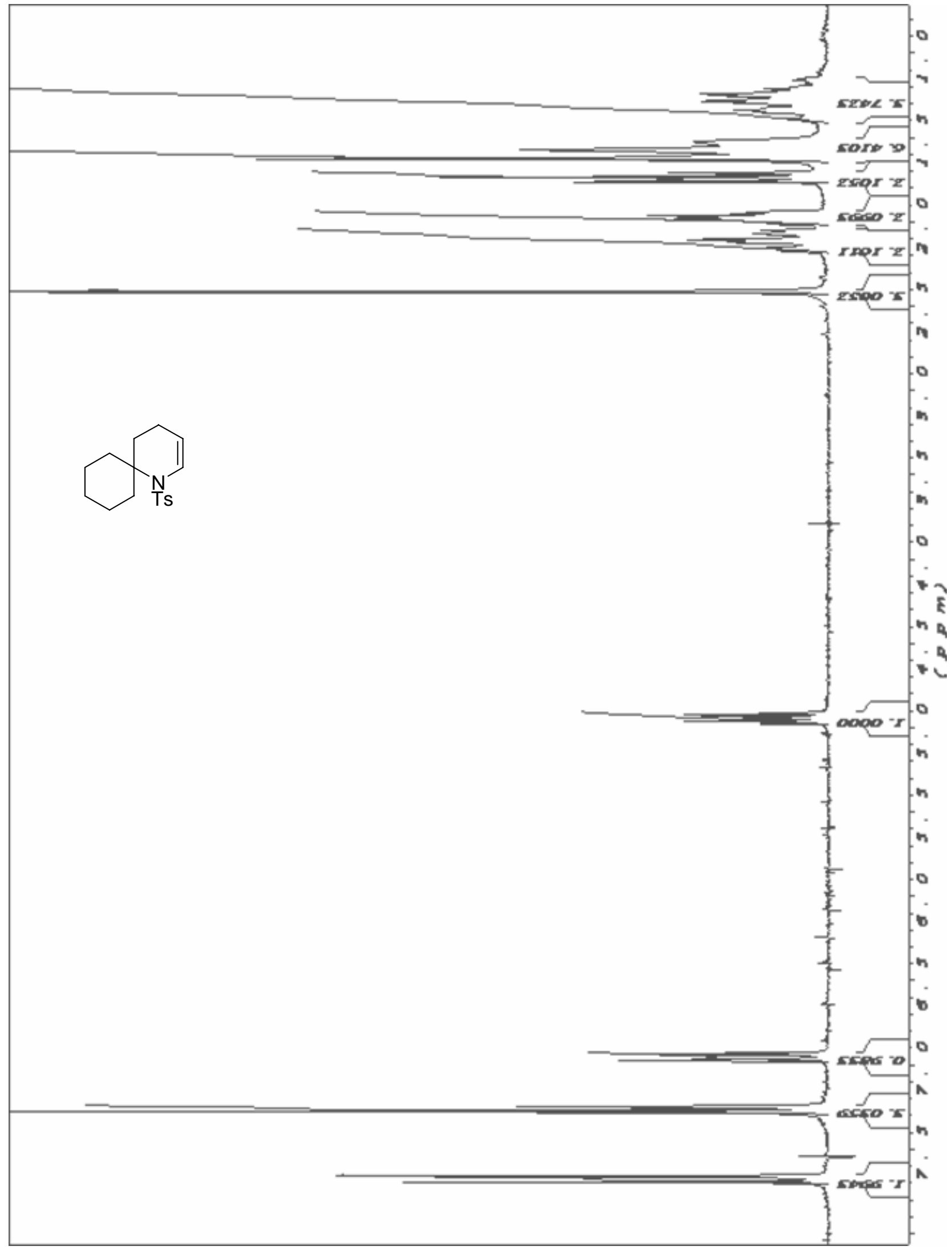




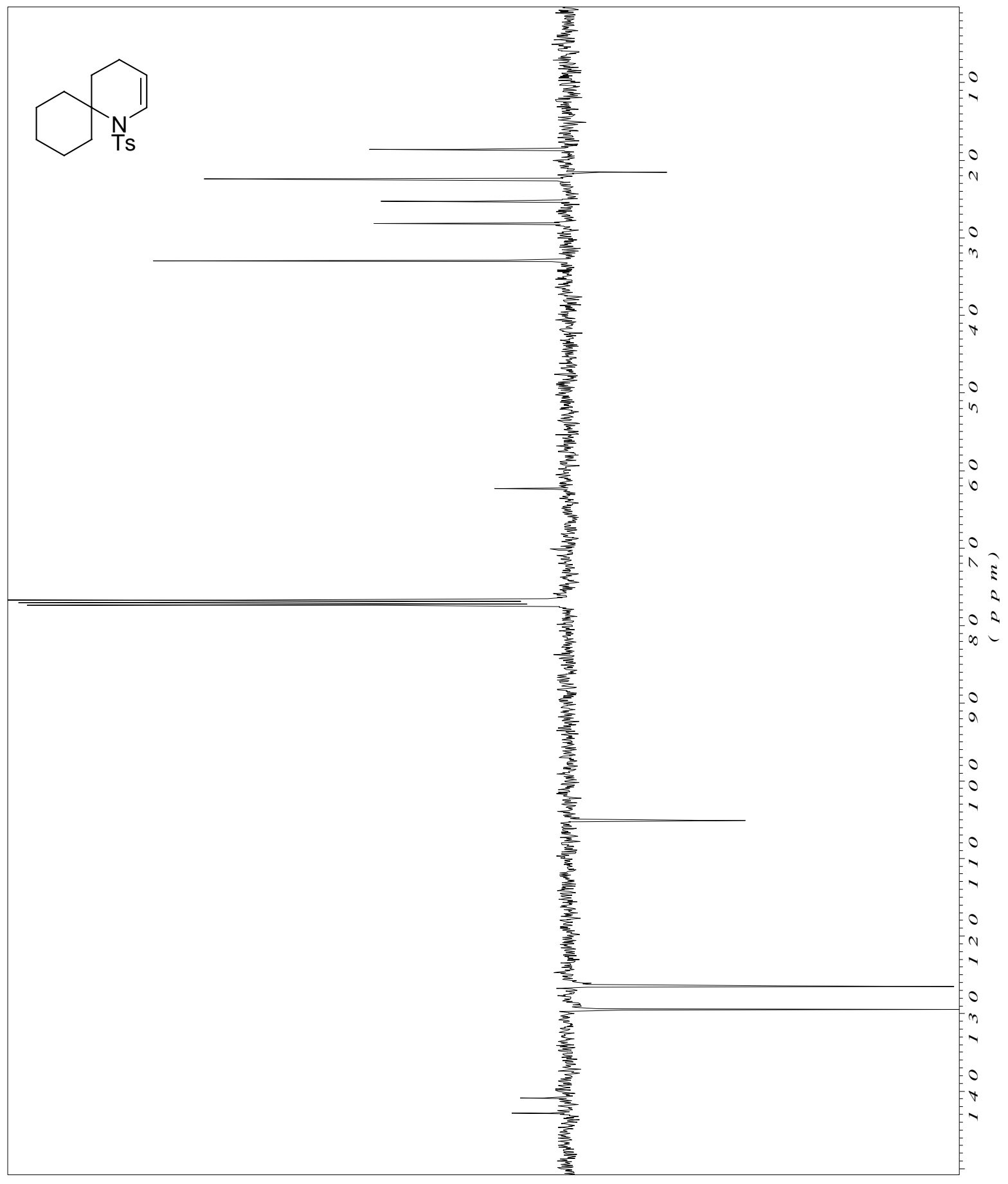


N-[4-tert-butyl-1-(3-[1,3]dioxolan-2-yl-propyl)-cyclohexyl]-4-methyl-

benzenesulfonamide 28

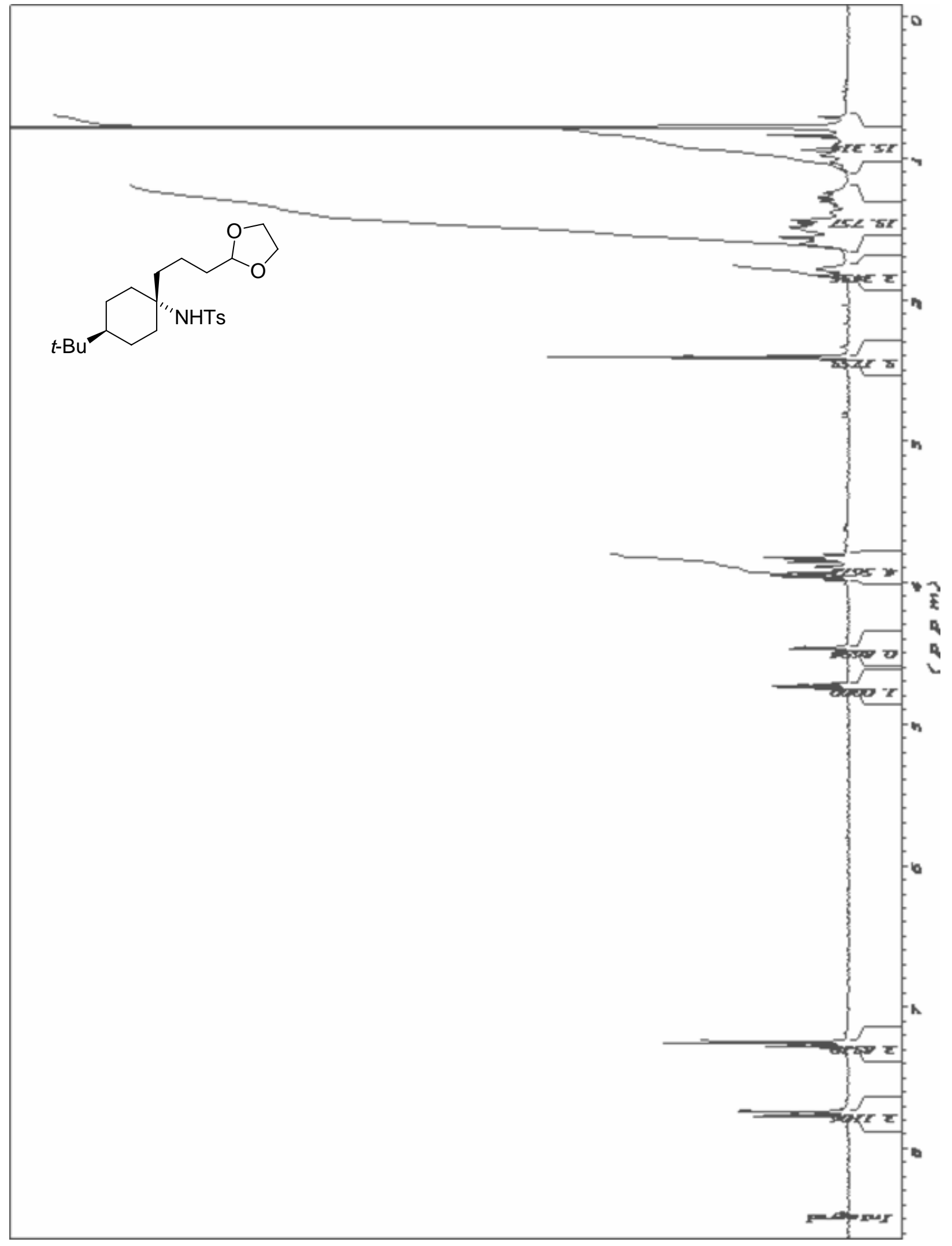




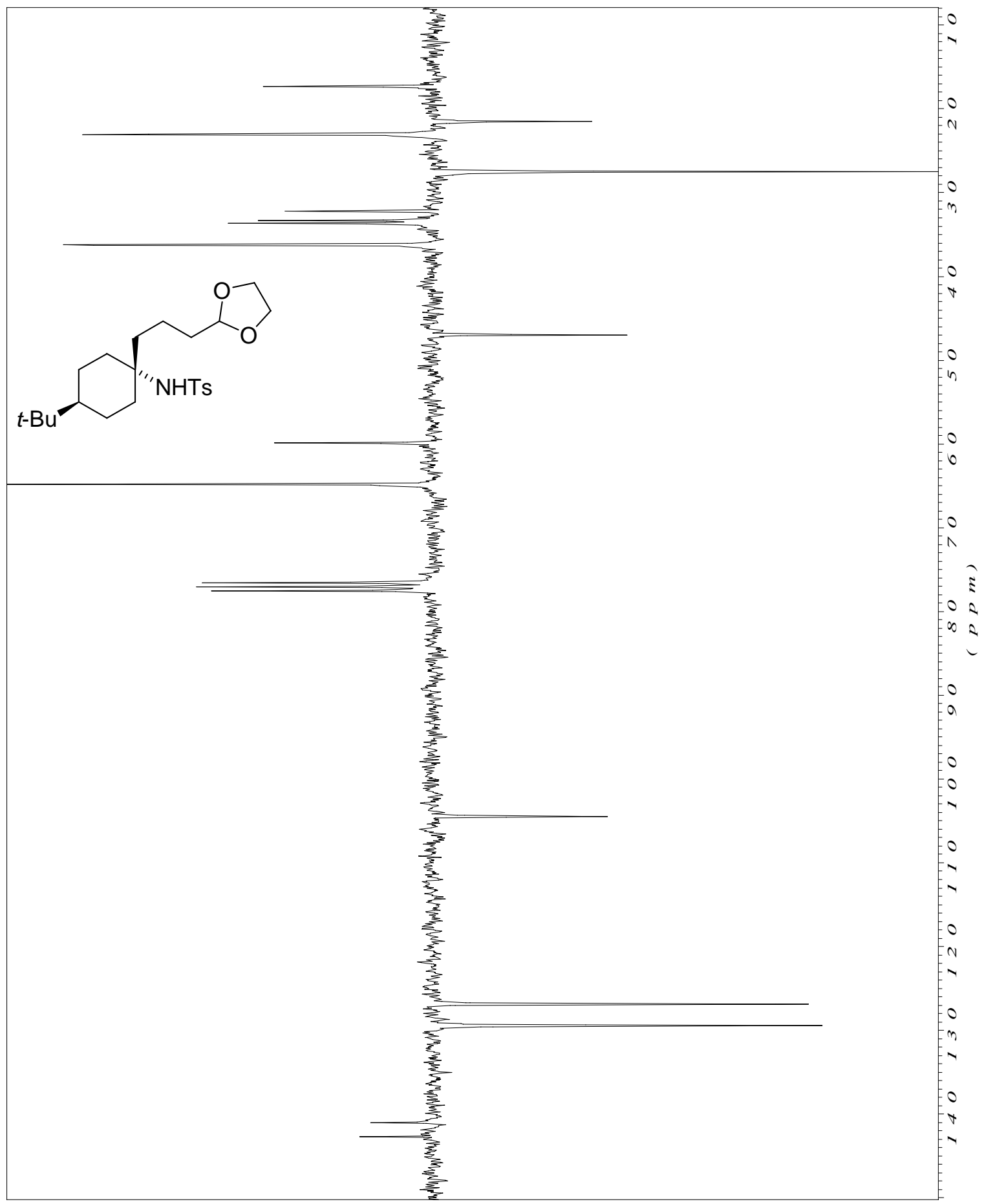


9-tert-butyl-1-(toluene-4-sulfonyl)-1-aza-spiro[5.5]undec-2-ene 29

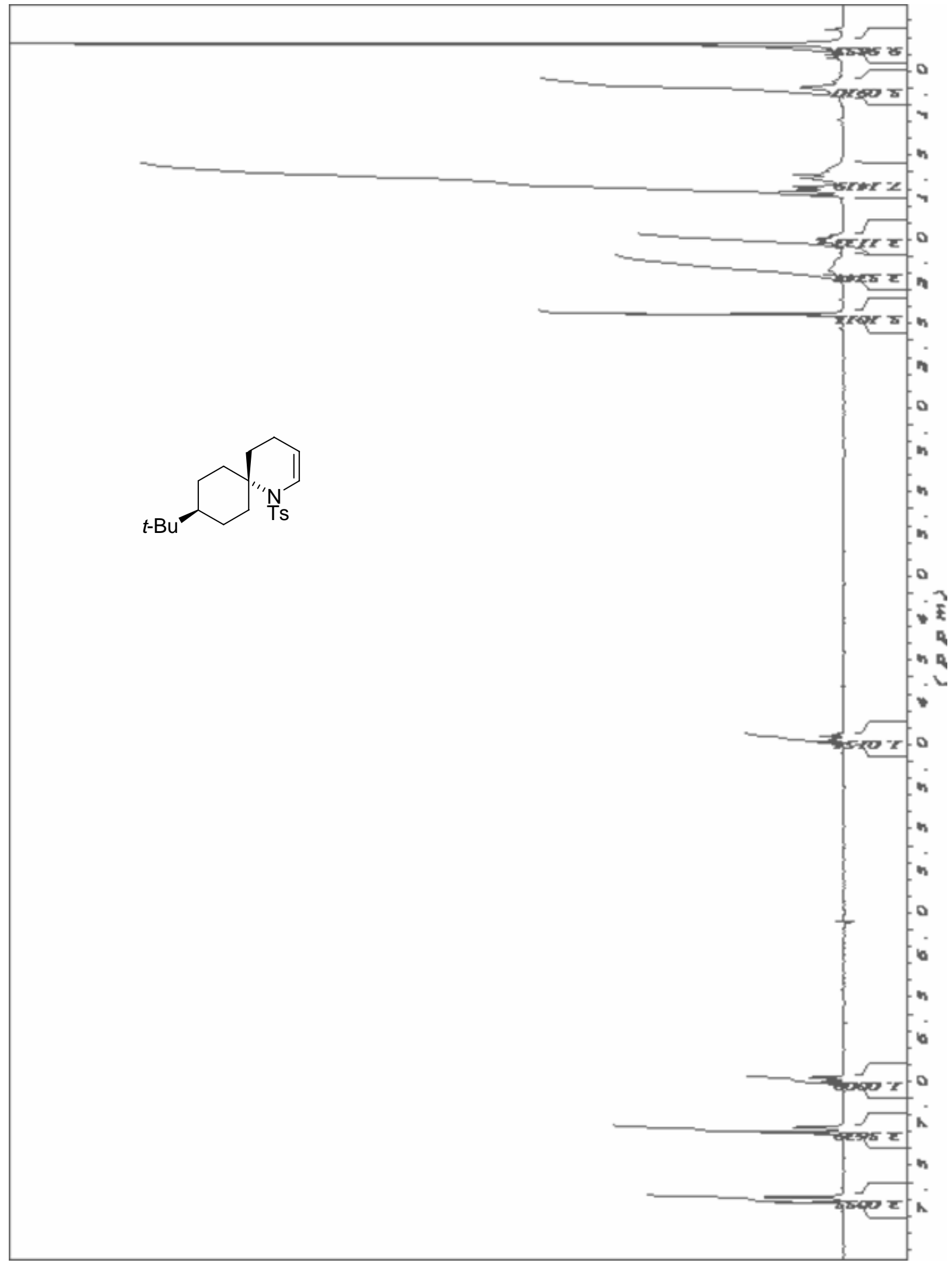




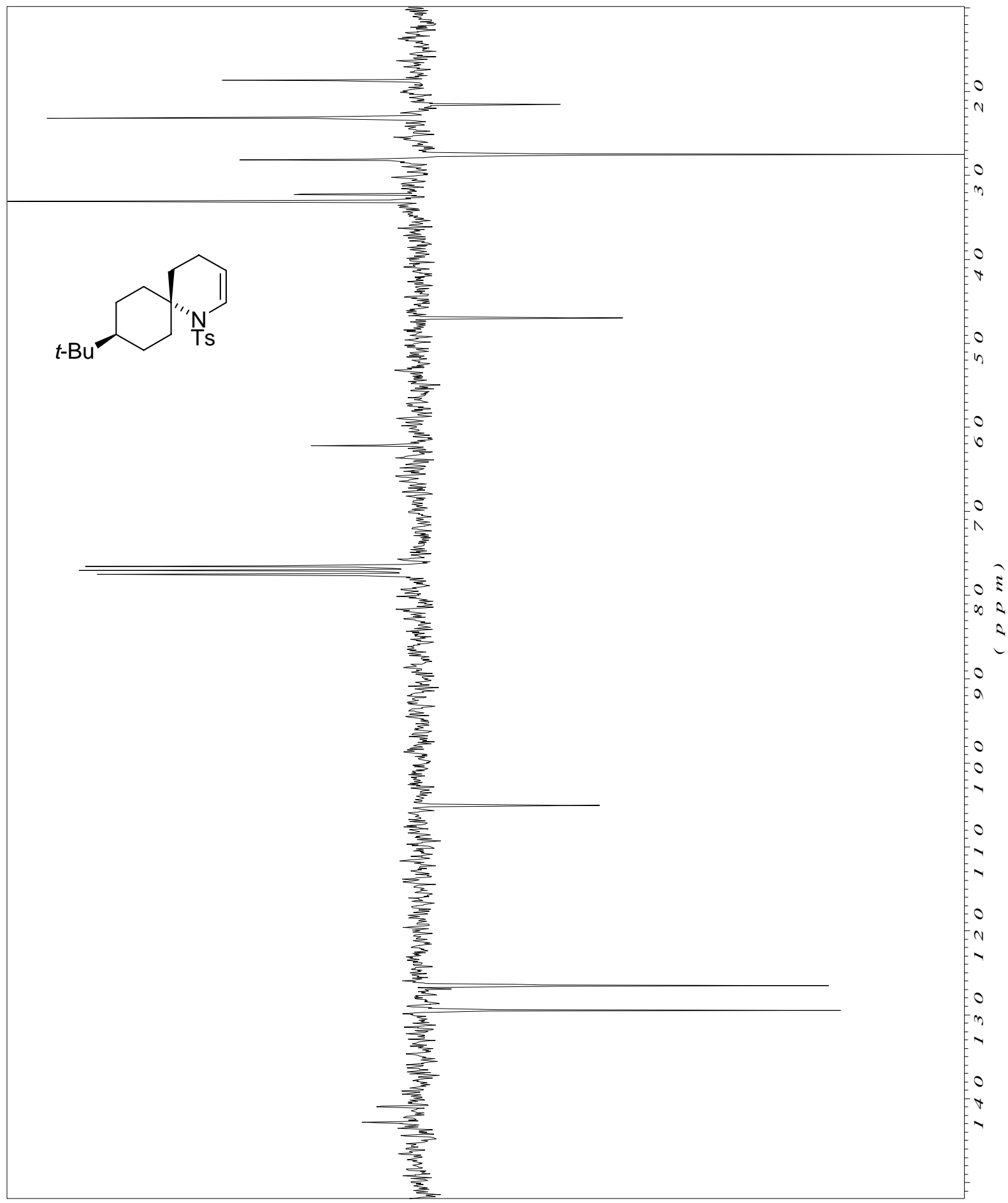


(S)-2-allyl-6-benzyl-1-(toluene-4-sulfonyl)-piperidine 30

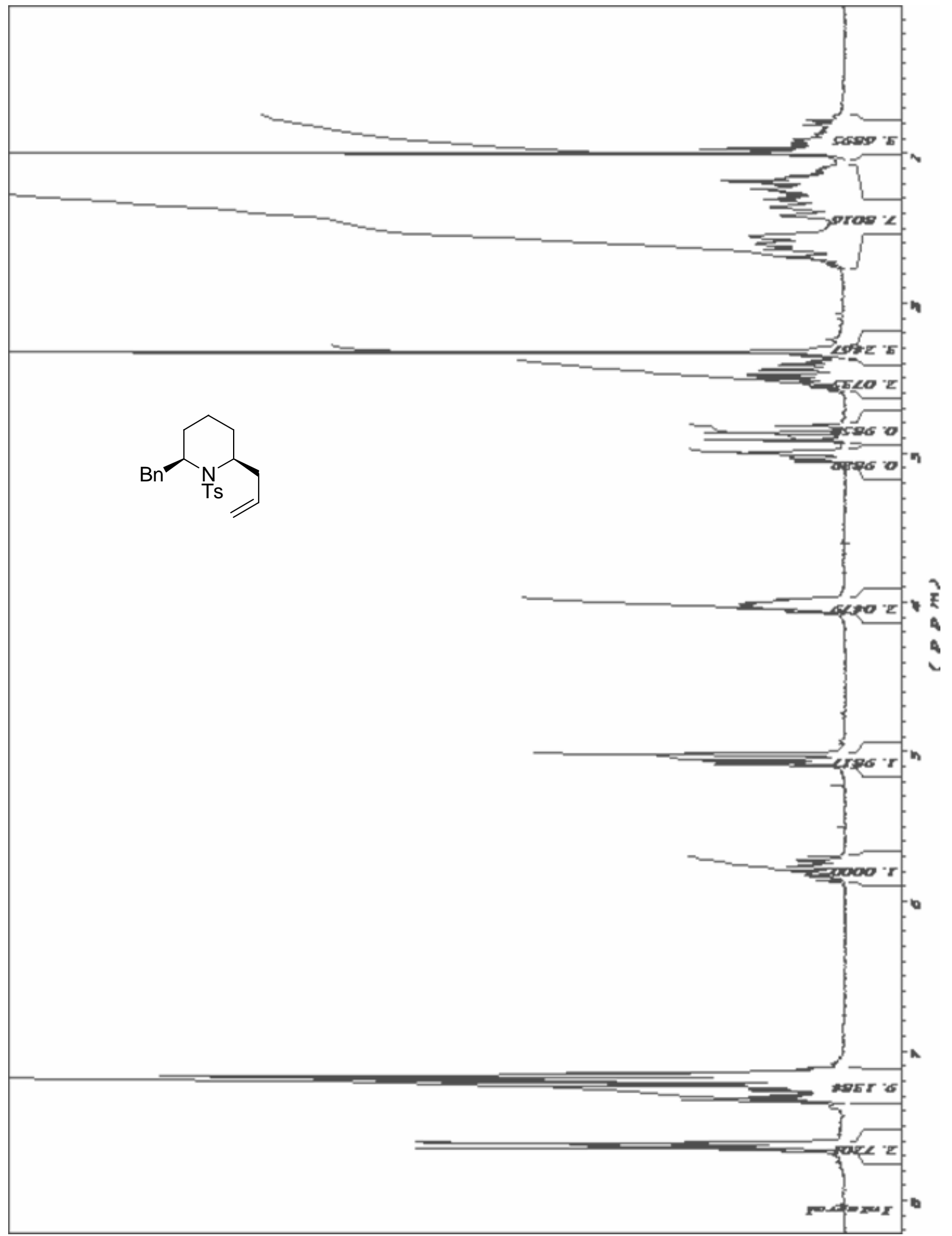




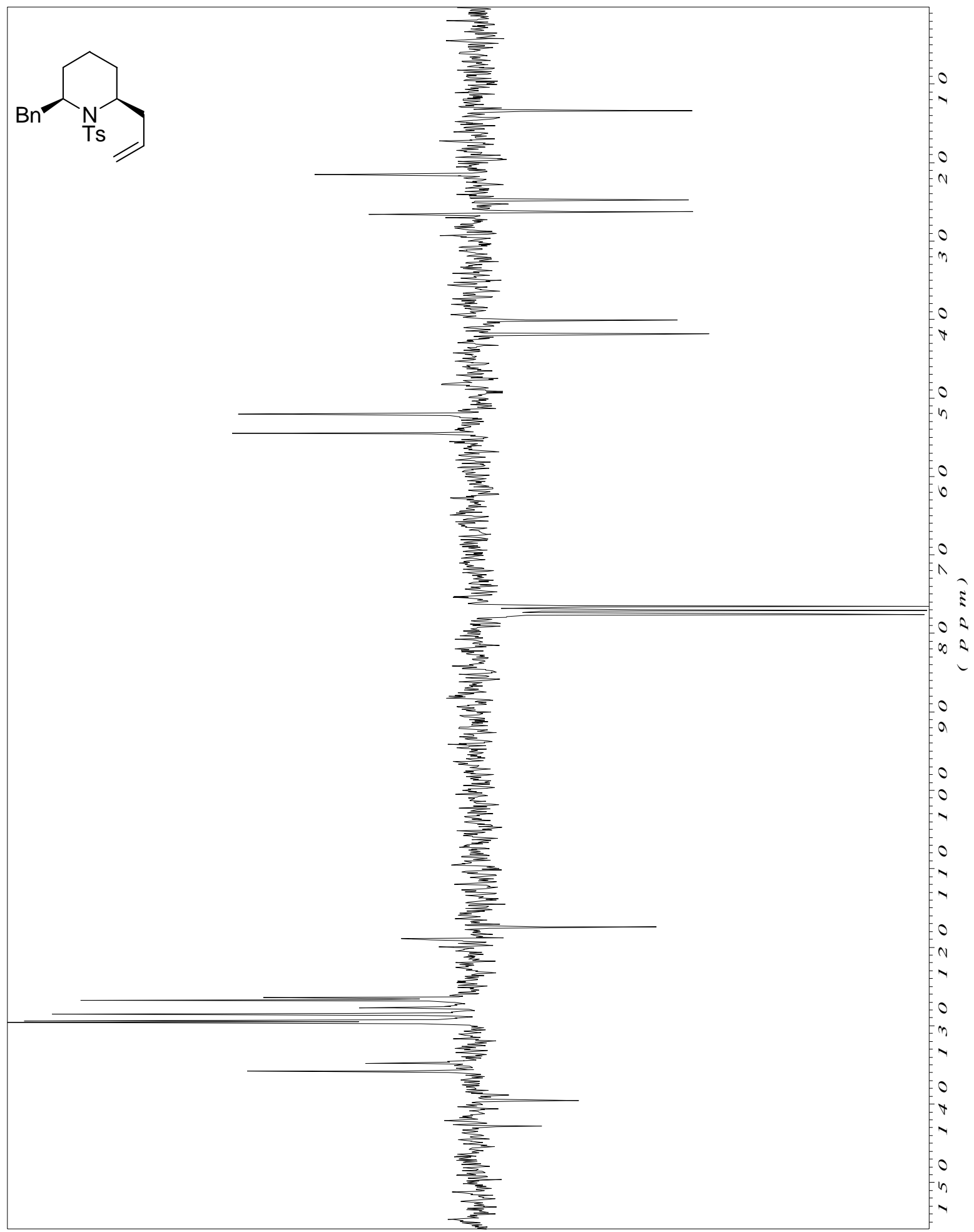


acetic acid 2-acetoxy-6-benzyl-1-(toluene-4-sulfonyl)-piperidin-3-yl ester 31

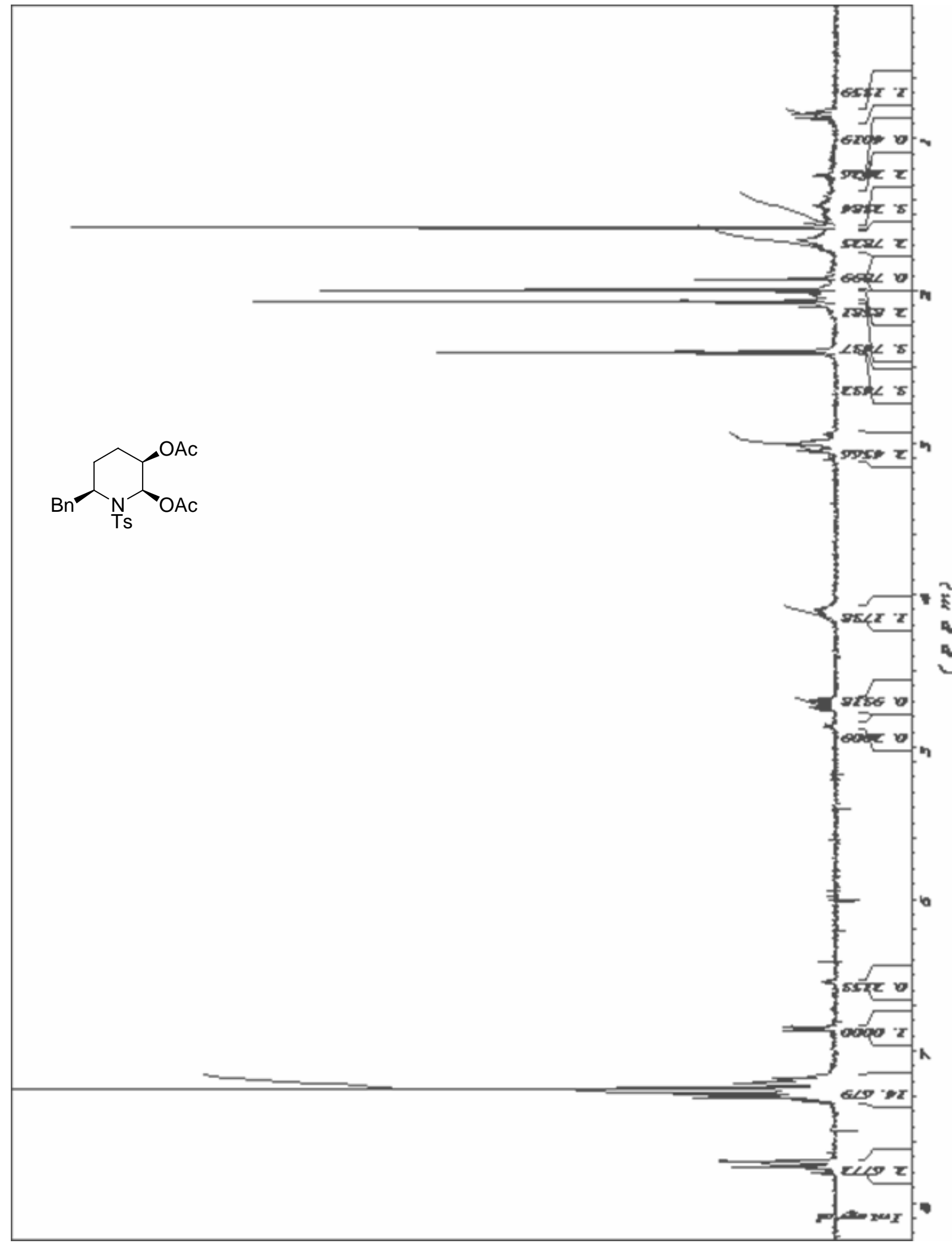




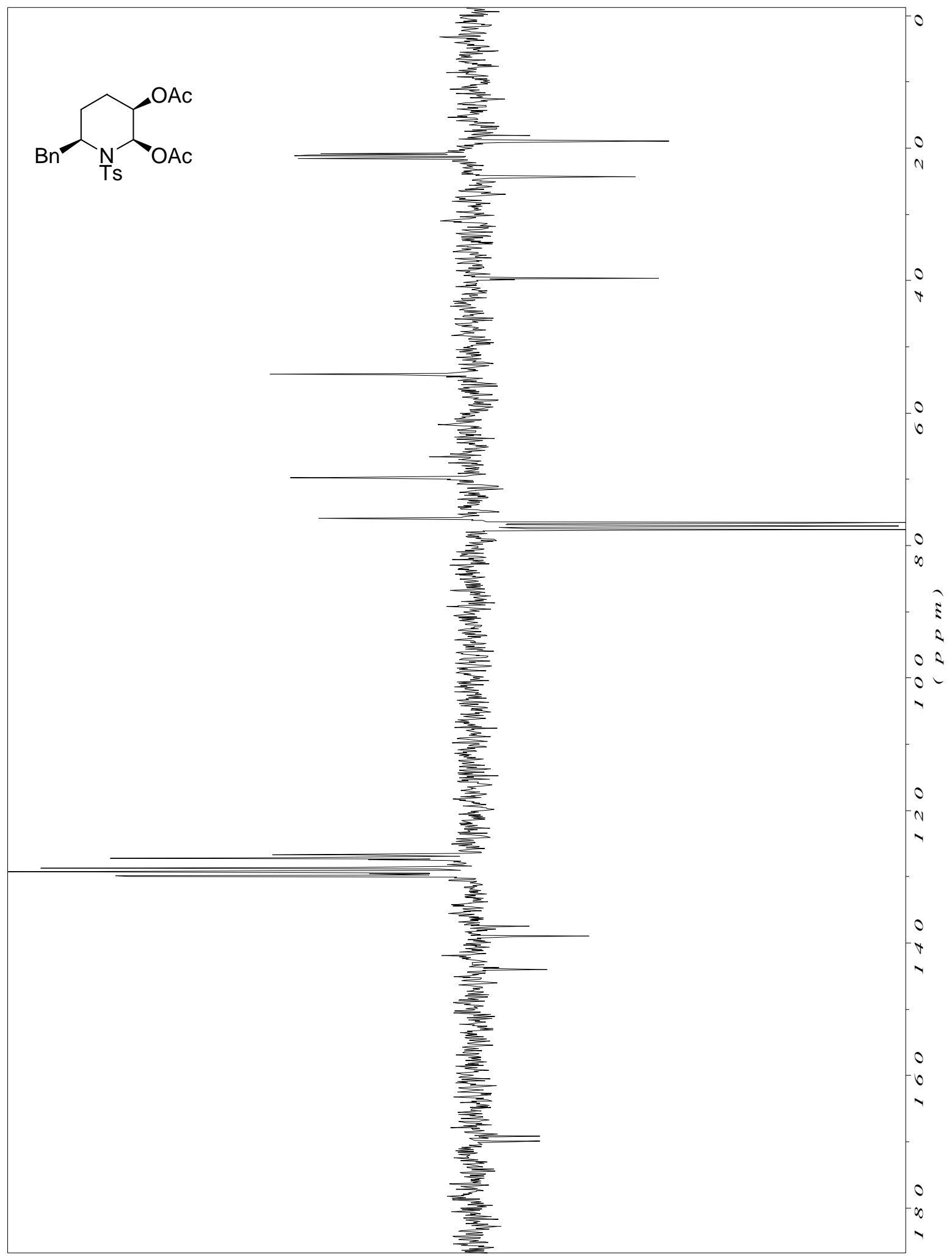


2-benzyl-5-bromo-1-(toluene-4-sulfonyl)-1,2,3,4-tetrahydropyridine 32

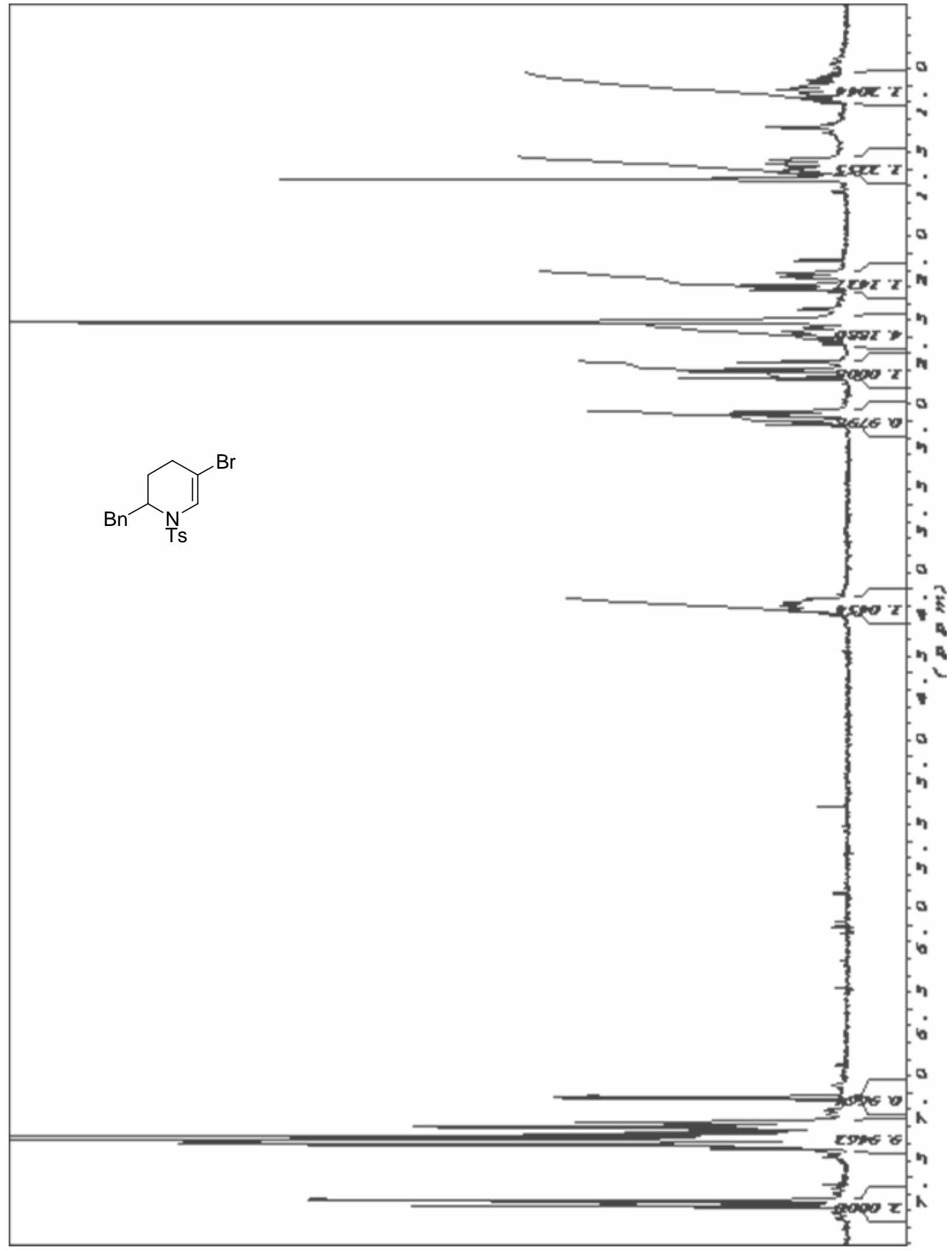




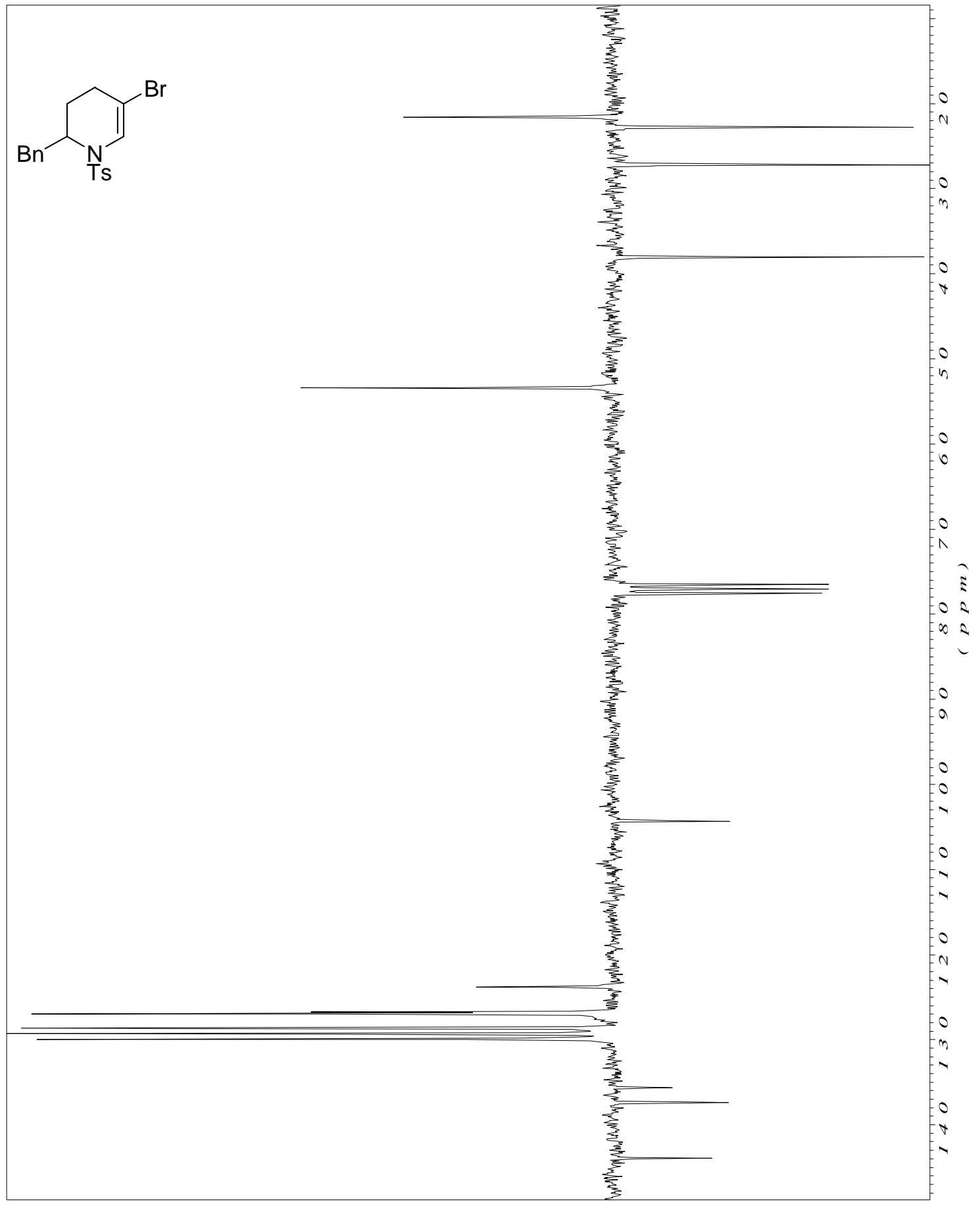


(R)-2-allyl-6-methyl-1-(toluene-4-sulfonyl)-piperidine 33

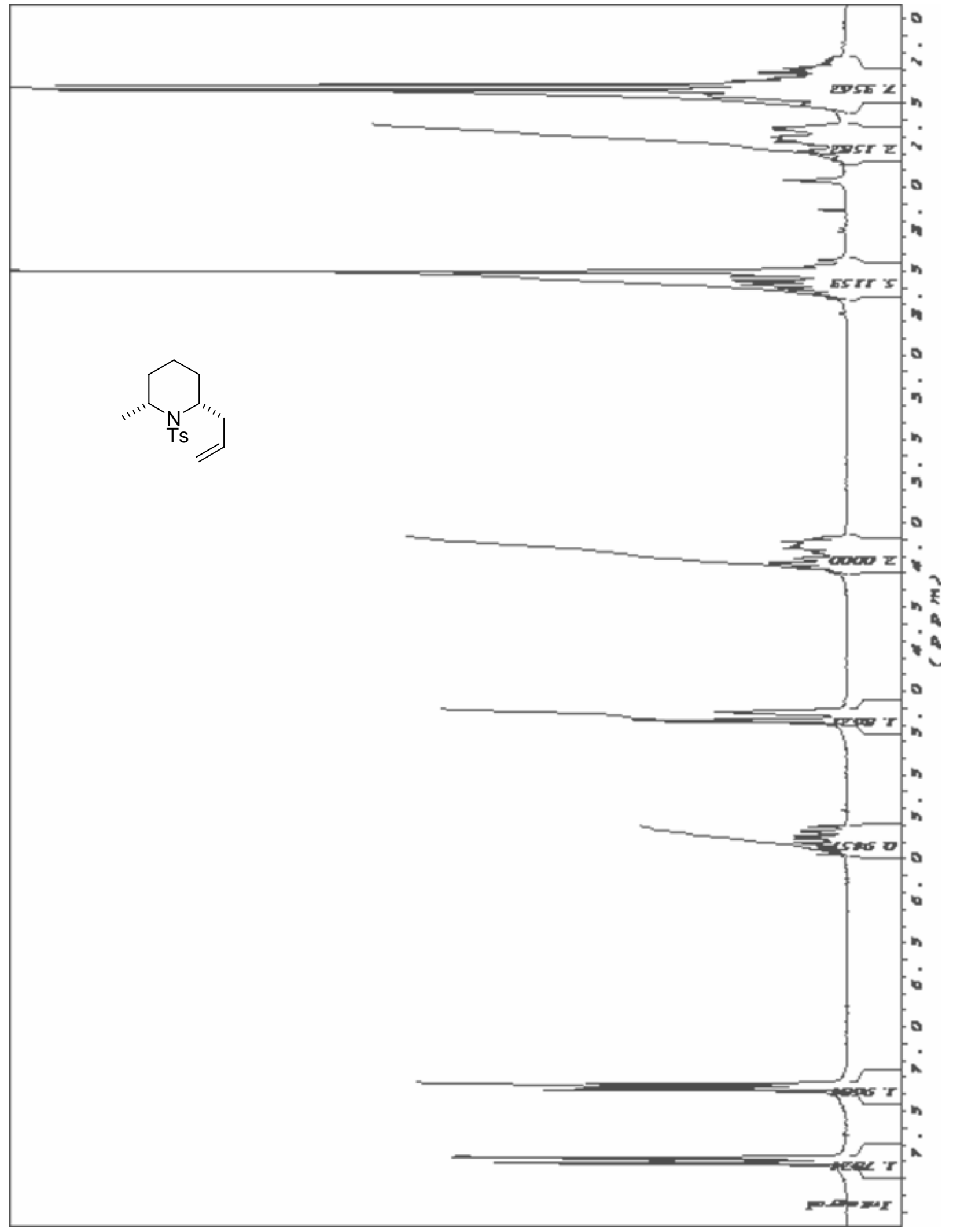




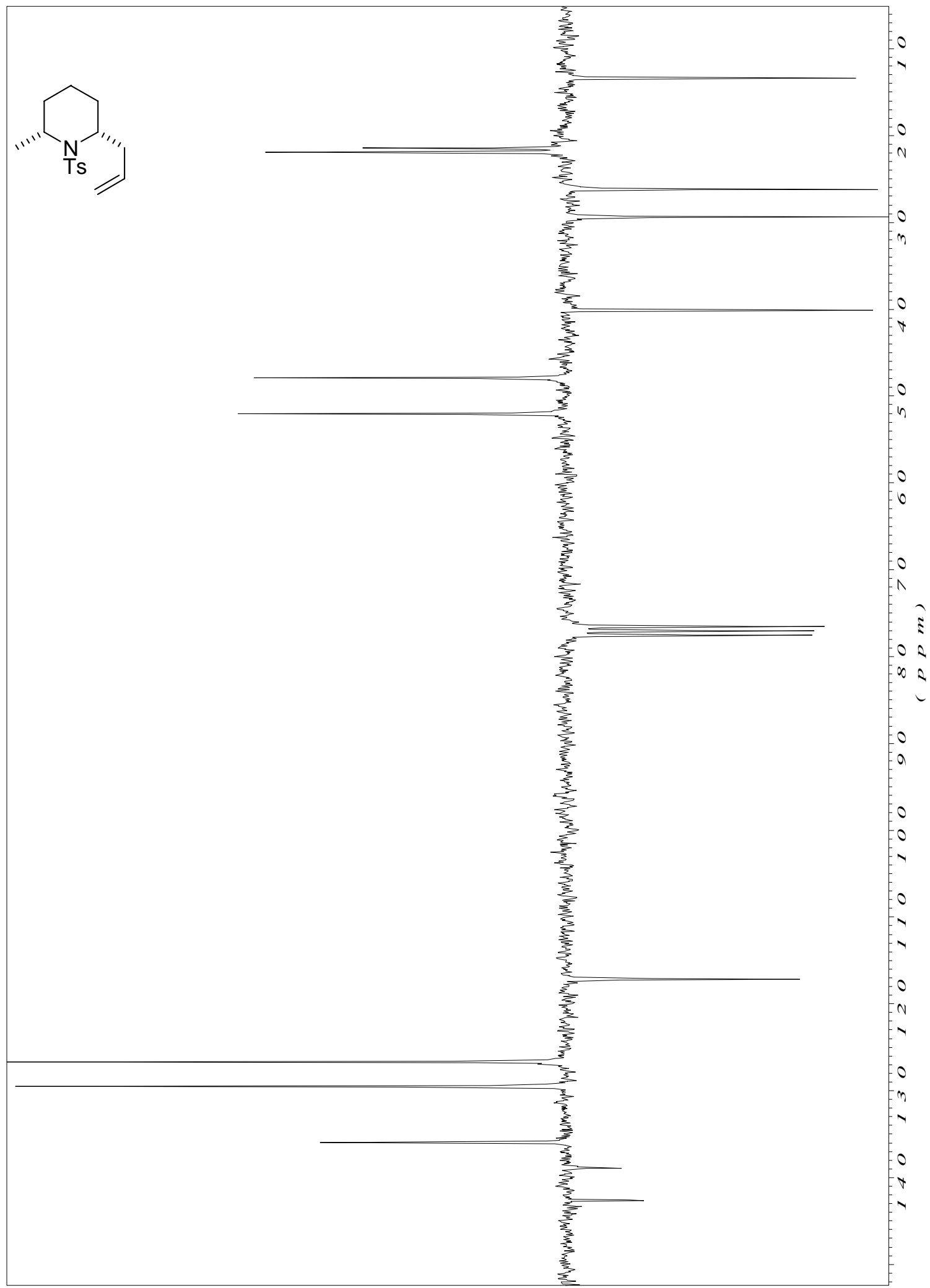


2-methyl-6-propyl-1-(toluene-4-sulfonyl)-piperidine 34

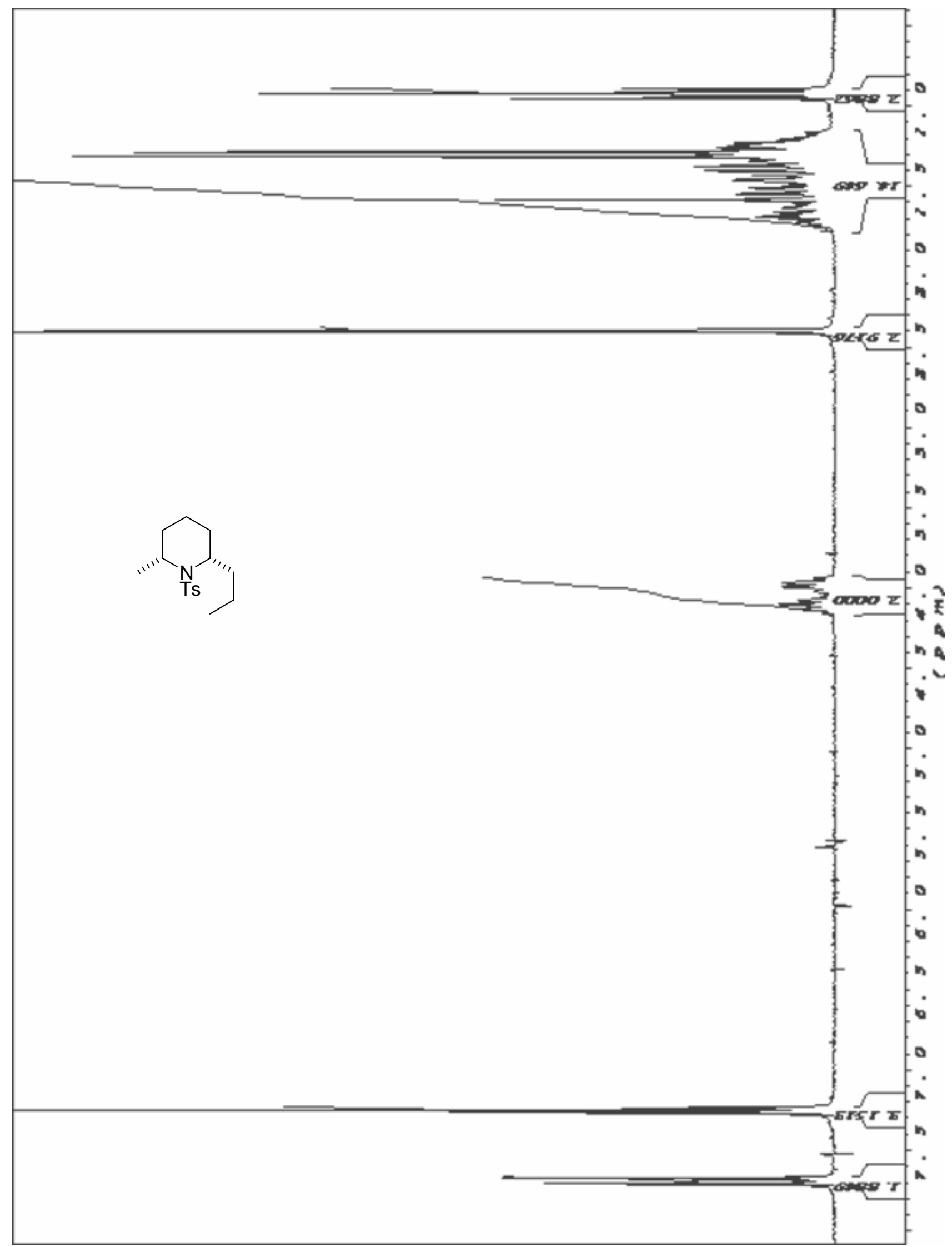




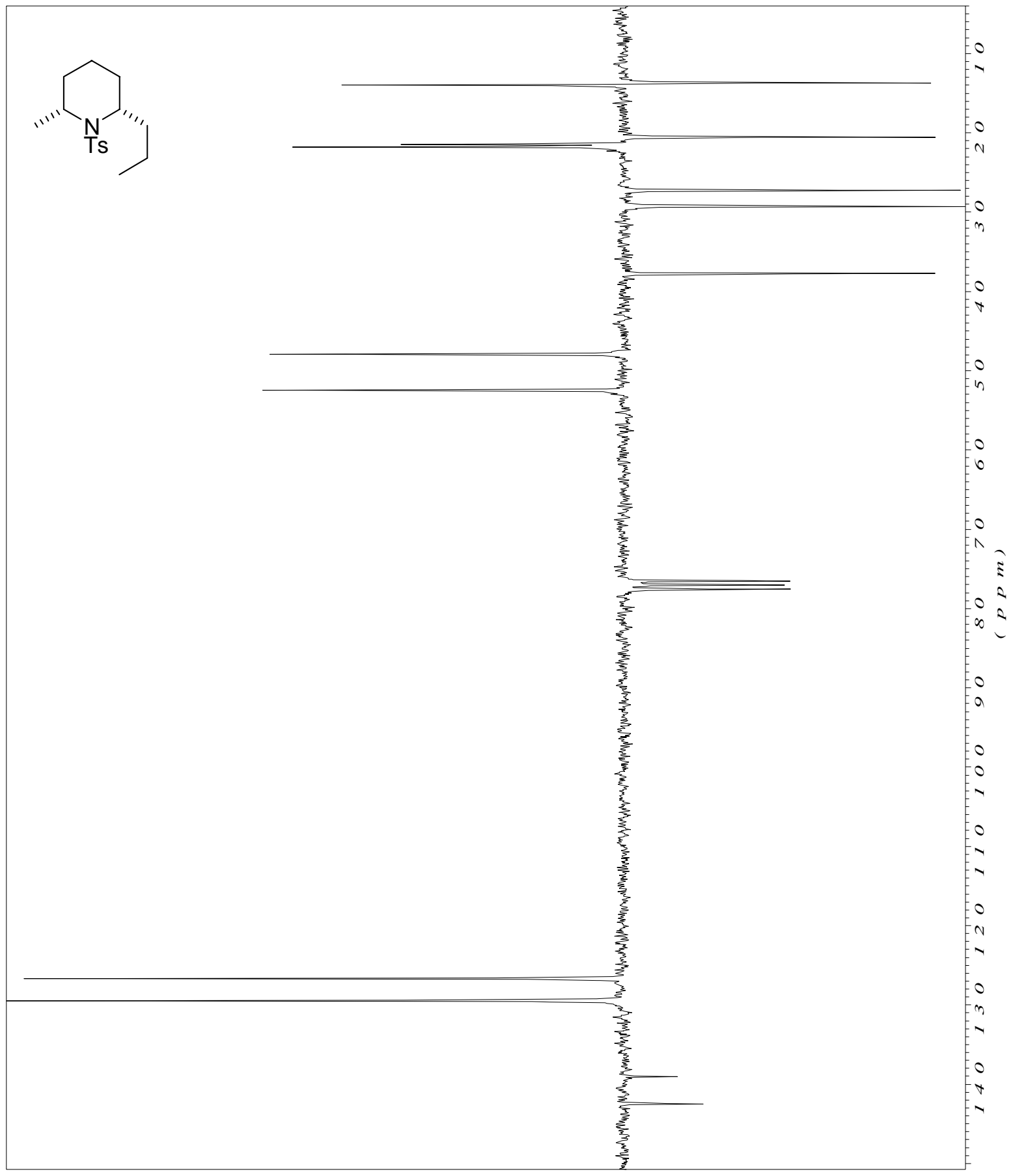




\section{Chromatographs:}

(R)-2-Benzyl-1-(toluene-4-sulfonyl)-1,2,3,4-tetrahydropyridine 11
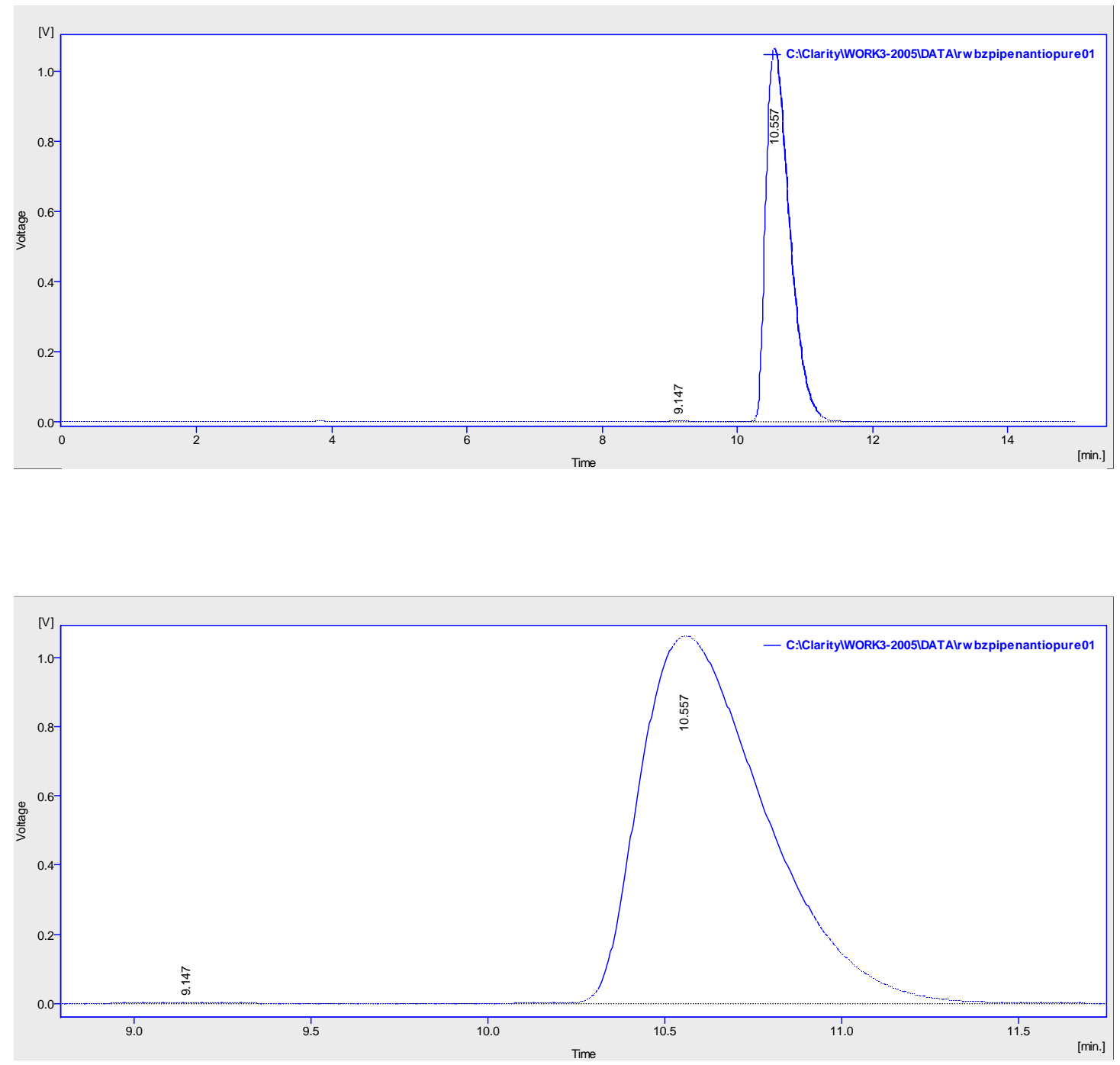

\begin{tabular}{|l|l|l|l|l|l|l|}
\hline & Reten. Time [min] & Area [mV.s] & Height [mV] & Area [\%] & Height [\%] & W05 [min] \\
\hline 1 & 9.147 & 76.152 & 2.782 & 0.3 & 0.3 & 0.41 \\
\hline 2 & 10.557 & 26190.228 & 1064.874 & 99.7 & 99.7 & 0.38 \\
\hline & Total & 26266.380 & 1067.656 & 100.0 & 100.0 & \\
\hline
\end{tabular}


2-Benzyl-1-(toluene-4-sulfonyl)-1,2,3,4-tetrahydropyridine 11
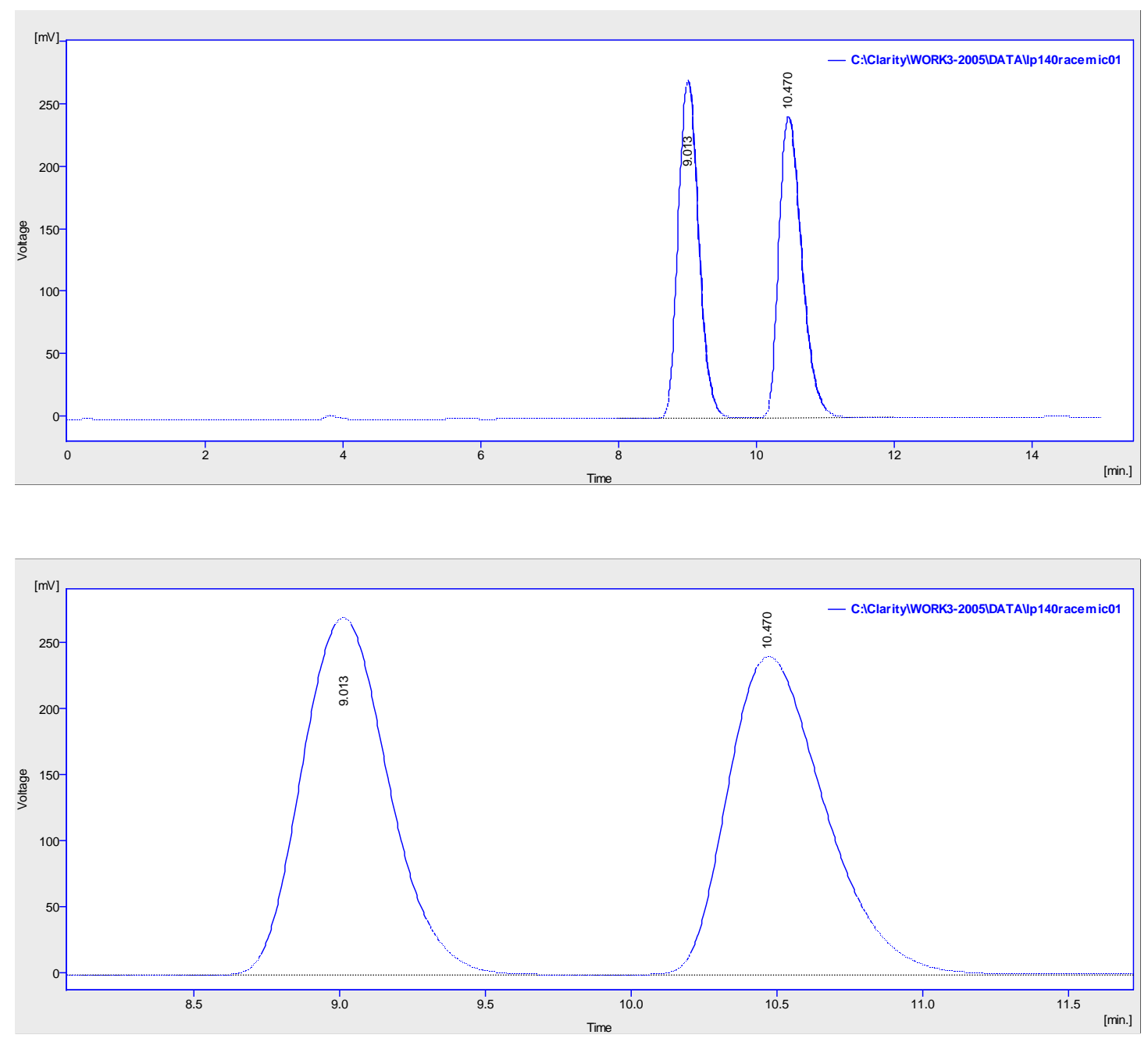

\begin{tabular}{|l|c|l|c|c|l|c|}
\hline & Reten. Time [min] & Area [mV.s] & Height [mV] & Area [\%] & Height [\%] & W05 [min] \\
\hline 1 & 9.013 & 5605.194 & 270.743 & 50.0 & 52.9 & 0.33 \\
\hline 2 & 10.470 & 5596.156 & 241.169 & 50.0 & 47.1 & 0.36 \\
\hline & Total & 11201.349 & 511.912 & 100.0 & 100.0 & \\
\hline
\end{tabular}




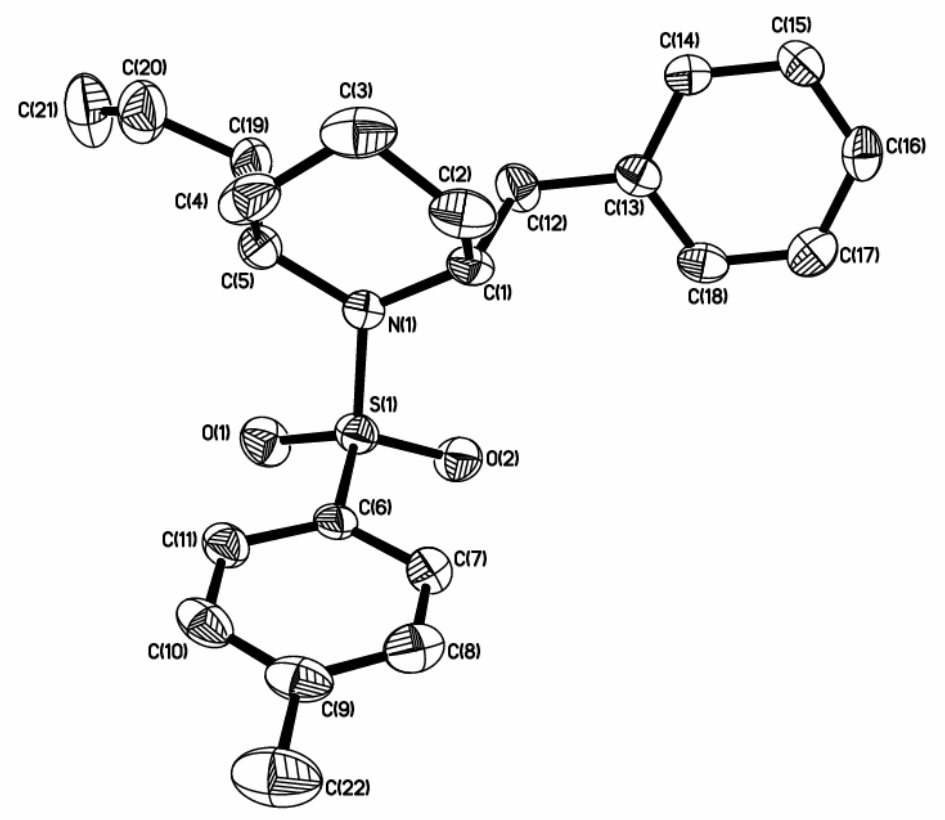

Table 1. Crystal data and structure refinement for rowan $1 \mathrm{~m}$.

Identification code

Empirical formula

Formula weight

Temperature

Wavelength

Crystal system

Space group

Unit cell dimensions

Volume

Z

Density (calculated)

Absorption coefficient

$\mathrm{F}(000)$

Crystal size

Theta range for data collection

Index ranges rowan1m

C22 H27 N O2 S

369.51

150(2) K

$0.71073 \AA$

Orthorhombic

$\mathrm{P} 2{ }_{1} 2_{1} 2_{1}$

$\mathrm{a}=8.084(3) \AA$

$\alpha=90^{\circ}$.

$\mathrm{b}=15.313(6) \AA$

$\beta=90^{\circ}$.

$c=16.268(6) \AA$

$\gamma=90^{\circ}$.
4

$1.219 \mathrm{Mg} / \mathrm{m}^{3}$

$0.176 \mathrm{~mm}^{-1}$

792

$0.41 \times 0.32 \times 0.28 \mathrm{~mm}^{3}$

1.83 to $27.57^{\circ}$.

$-10<=\mathrm{h}<=10,-19<=\mathrm{k}<=19,-20<=\mathrm{l}<=20$ 
Reflections collected

Independent reflections

Completeness to theta $=27.57^{\circ}$

Absorption correction

Max. and min. transmission

Refinement method

Data / restraints / parameters

Goodness-of-fit on $\mathrm{F}^{2}$

Final R indices [I $>2 \operatorname{sigma(I)]~}$

$\mathrm{R}$ indices (all data)

Absolute structure parameter

Largest diff. peak and hole
23080

$4566[\mathrm{R}(\mathrm{int})=0.0716]$

$99.1 \%$

Semi-empirical from equivalents

0.9524 and 0.9313

Full-matrix least-squares on $\mathrm{F}^{2}$

4566 / 0 / 236

1.019

$\mathrm{R} 1=0.0476, \mathrm{wR} 2=0.0886$

$\mathrm{R} 1=0.0842, \mathrm{wR} 2=0.1006$

$-0.03(9)$

0.543 and -0.354 e. $\AA^{-3}$

Table 2. Atomic coordinates ( $\left.\mathrm{x} 10^{4}\right)$ and equivalent isotropic displacement parameters $\left(\AA^{2} \mathrm{x} 10^{3}\right)$ for rowan $1 \mathrm{~m}$. $U(\mathrm{eq})$ is defined as one third of the trace of the orthogonalized $U^{i j}$ tensor.

\begin{tabular}{|c|c|c|c|c|}
\hline & $\mathrm{x}$ & $\mathrm{y}$ & $\mathrm{z}$ & $\mathrm{U}(\mathrm{eq})$ \\
\hline$S(1)$ & 1195(1) & 9591(1) & $3682(1)$ & $30(1)$ \\
\hline $\mathrm{N}(1)$ & 1153(3) & $9610(2)$ & $4673(1)$ & $30(1)$ \\
\hline $\mathrm{O}(1)$ & $1545(2)$ & $8712(1)$ & $3433(1)$ & $40(1)$ \\
\hline $\mathrm{O}(2)$ & $-286(2)$ & 10014(1) & 3398(1) & $36(1)$ \\
\hline$C(1)$ & $347(3)$ & 10356(2) & $5099(2)$ & $29(1)$ \\
\hline $\mathrm{C}(2)$ & $1542(4)$ & 10806(2) & $5684(2)$ & $42(1)$ \\
\hline C(3) & $2469(4)$ & $10170(2)$ & $6230(2)$ & $50(1)$ \\
\hline$C(4)$ & 3403(3) & $9518(2)$ & $5701(2)$ & $48(1)$ \\
\hline C(5) & 2251(3) & $9007(2)$ & $5142(2)$ & $37(1)$ \\
\hline C(6) & 2880(3) & $10241(2)$ & 3361(2) & $26(1)$ \\
\hline C(7) & 2633(3) & $11124(2)$ & $3194(2)$ & $34(1)$ \\
\hline C(8) & $3959(4)$ & $11627(2)$ & $2948(2)$ & $41(1)$ \\
\hline C(9) & $5537(4)$ & $11279(2)$ & $2855(2)$ & $38(1)$ \\
\hline$C(10)$ & $5749(3)$ & 10399(2) & $3032(2)$ & $37(1)$ \\
\hline$C(11)$ & $4440(3)$ & $9876(2)$ & $3284(2)$ & $32(1)$ \\
\hline$C(12)$ & $-1287(4)$ & $10080(2)$ & $5515(2)$ & $34(1)$ \\
\hline$C(13)$ & $-2466(3)$ & $10825(2)$ & $5655(2)$ & $29(1)$ \\
\hline $\mathrm{C}(14)$ & $-2976(3)$ & 11064(2) & $6441(2)$ & $34(1)$ \\
\hline$C(15)$ & $-4140(3)$ & $11720(2)$ & $6559(2)$ & $37(1)$ \\
\hline$C(16)$ & $-4780(3)$ & $12159(2)$ & $5890(2)$ & $36(1)$ \\
\hline
\end{tabular}




\begin{tabular}{lrrrl}
$\mathrm{C}(17)$ & $-4279(3)$ & $11935(2)$ & $5109(2)$ & $36(1)$ \\
$\mathrm{C}(18)$ & $-3136(3)$ & $11281(2)$ & $4994(2)$ & $32(1)$ \\
$\mathrm{C}(19)$ & $1207(4)$ & $8314(2)$ & $5591(2)$ & $39(1)$ \\
$\mathrm{C}(20)$ & $2237(4)$ & $7585(2)$ & $5936(2)$ & $57(1)$ \\
$\mathrm{C}(21)$ & $2066(5)$ & $6803(2)$ & $5807(3)$ & $67(1)$ \\
$\mathrm{C}(22)$ & $6966(4)$ & $11836(2)$ & $2564(2)$ & $61(1)$ \\
\hline
\end{tabular}

Table 3. Bond lengths $[\AA]$ and angles $\left[{ }^{\circ}\right]$ for rowan $1 \mathrm{~m}$.

\begin{tabular}{ll}
\hline $\mathrm{S}(1)-\mathrm{O}(1)$ & $1.433(2)$ \\
$\mathrm{S}(1)-\mathrm{O}(2)$ & $1.4375(19)$ \\
$\mathrm{S}(1)-\mathrm{N}(1)$ & $1.613(2)$ \\
$\mathrm{S}(1)-\mathrm{C}(6)$ & $1.766(3)$ \\
$\mathrm{N}(1)-\mathrm{C}(1)$ & $1.487(3)$ \\
$\mathrm{N}(1)-\mathrm{C}(5)$ & $1.490(3)$ \\
$\mathrm{C}(1)-\mathrm{C}(2)$ & $1.521(4)$ \\
$\mathrm{C}(1)-\mathrm{C}(12)$ & $1.543(4)$ \\
$\mathrm{C}(1)-\mathrm{H}(1)$ & 0.9800 \\
$\mathrm{C}(2)-\mathrm{C}(3)$ & $1.516(4)$ \\
$\mathrm{C}(2)-\mathrm{H}(2 \mathrm{~A})$ & 0.9700 \\
$\mathrm{C}(2)-\mathrm{H}(2 \mathrm{~B})$ & 0.9700 \\
$\mathrm{C}(3)-\mathrm{C}(4)$ & $1.520(5)$ \\
$\mathrm{C}(3)-\mathrm{H}(3 \mathrm{~A})$ & 0.9700 \\
$\mathrm{C}(3)-\mathrm{H}(3 \mathrm{~B})$ & 0.9700 \\
$\mathrm{C}(4)-\mathrm{C}(5)$ & $1.518(4)$ \\
$\mathrm{C}(4)-\mathrm{H}(4 \mathrm{~A})$ & 0.9700 \\
$\mathrm{C}(4)-\mathrm{H}(4 \mathrm{~B})$ & 0.9700 \\
$\mathrm{C}(5)-\mathrm{C}(19)$ & $1.541(4)$ \\
$\mathrm{C}(5)-\mathrm{H}(5)$ & 0.9800 \\
$\mathrm{C}(6)-\mathrm{C}(11)$ & $1.385(3)$ \\
$\mathrm{C}(6)-\mathrm{C}(7)$ & $1.394(4)$ \\
$\mathrm{C}(7)-\mathrm{C}(8)$ & $1.380(4)$ \\
$\mathrm{C}(7)-\mathrm{H}(7)$ & 0.9300 \\
$\mathrm{C}(8)-\mathrm{C}(9)$ & $1.391(4)$ \\
$\mathrm{C}(8)-\mathrm{H}(8)$ & 0.9300 \\
$\mathrm{C}(9)-\mathrm{C}(10)$ & $1.390(4)$ \\
$\mathrm{C}(9)-\mathrm{C}(22)$ & $1.511(4)$ \\
&
\end{tabular}




\begin{tabular}{|c|c|}
\hline C(10)-C(11) & $1.388(4)$ \\
\hline $\mathrm{C}(10)-\mathrm{H}(10)$ & 0.9300 \\
\hline $\mathrm{C}(11)-\mathrm{H}(11)$ & 0.9300 \\
\hline $\mathrm{C}(12)-\mathrm{C}(13)$ & $1.504(4)$ \\
\hline $\mathrm{C}(12)-\mathrm{H}(12 \mathrm{~A})$ & 0.9700 \\
\hline $\mathrm{C}(12)-\mathrm{H}(12 \mathrm{~B})$ & 0.9700 \\
\hline C(13)-C(14) & $1.393(4)$ \\
\hline C(13)-C(18) & $1.391(4)$ \\
\hline C(14)-C(15) & $1.390(4)$ \\
\hline $\mathrm{C}(14)-\mathrm{H}(14)$ & 0.9300 \\
\hline C(15)-C(16) & $1.380(4)$ \\
\hline C(15)-H(15) & 0.9300 \\
\hline $\mathrm{C}(16)-\mathrm{C}(17)$ & $1.376(4)$ \\
\hline $\mathrm{C}(16)-\mathrm{H}(16)$ & 0.9300 \\
\hline C(17)-C(18) & $1.376(4)$ \\
\hline $\mathrm{C}(17)-\mathrm{H}(17)$ & 0.9300 \\
\hline C(18)-H(18) & 0.9300 \\
\hline C(19)-C(20) & $1.501(4)$ \\
\hline C(19)-H(19A) & 0.9700 \\
\hline C(19)-H(19B) & 0.9700 \\
\hline$C(20)-C(21)$ & $1.224(4)$ \\
\hline C(20)-H(20) & 0.9300 \\
\hline $\mathrm{C}(21)-\mathrm{H}(21 \mathrm{~A})$ & 0.9300 \\
\hline $\mathrm{C}(21)-\mathrm{H}(21 \mathrm{~B})$ & 0.9300 \\
\hline $\mathrm{C}(22)-\mathrm{H}(22 \mathrm{~A})$ & 0.9600 \\
\hline $\mathrm{C}(22)-\mathrm{H}(22 \mathrm{~B})$ & 0.9600 \\
\hline $\mathrm{C}(22)-\mathrm{H}(22 \mathrm{C})$ & 0.9600 \\
\hline $\mathrm{O}(1)-\mathrm{S}(1)-\mathrm{O}(2)$ & $119.85(12)$ \\
\hline $\mathrm{O}(1)-\mathrm{S}(1)-\mathrm{N}(1)$ & $107.66(12)$ \\
\hline $\mathrm{O}(2)-\mathrm{S}(1)-\mathrm{N}(1)$ & $107.20(12)$ \\
\hline $\mathrm{O}(1)-\mathrm{S}(1)-\mathrm{C}(6)$ & $107.06(12)$ \\
\hline $\mathrm{O}(2)-\mathrm{S}(1)-\mathrm{C}(6)$ & $107.01(12)$ \\
\hline$N(1)-S(1)-C(6)$ & $107.52(12)$ \\
\hline $\mathrm{C}(1)-\mathrm{N}(1)-\mathrm{C}(5)$ & $119.9(2)$ \\
\hline $\mathrm{C}(1)-\mathrm{N}(1)-\mathrm{S}(1)$ & 119.32(18) \\
\hline$C(5)-N(1)-S(1)$ & 119.19(18) \\
\hline $\mathrm{N}(1)-\mathrm{C}(1)-\mathrm{C}(2)$ & $111.2(2)$ \\
\hline
\end{tabular}




\begin{tabular}{|c|c|}
\hline $\mathrm{N}(1)-\mathrm{C}(1)-\mathrm{C}(12)$ & $111.7(2)$ \\
\hline $\mathrm{C}(2)-\mathrm{C}(1)-\mathrm{C}(12)$ & $113.2(2)$ \\
\hline $\mathrm{N}(1)-\mathrm{C}(1)-\mathrm{H}(1)$ & 106.8 \\
\hline $\mathrm{C}(2)-\mathrm{C}(1)-\mathrm{H}(1)$ & 106.8 \\
\hline $\mathrm{C}(12)-\mathrm{C}(1)-\mathrm{H}(1)$ & 106.8 \\
\hline $\mathrm{C}(3)-\mathrm{C}(2)-\mathrm{C}(1)$ & 112.8(3) \\
\hline $\mathrm{C}(3)-\mathrm{C}(2)-\mathrm{H}(2 \mathrm{~A})$ & 109.0 \\
\hline $\mathrm{C}(1)-\mathrm{C}(2)-\mathrm{H}(2 \mathrm{~A})$ & 109.0 \\
\hline $\mathrm{C}(3)-\mathrm{C}(2)-\mathrm{H}(2 \mathrm{~B})$ & 109.0 \\
\hline $\mathrm{C}(1)-\mathrm{C}(2)-\mathrm{H}(2 \mathrm{~B})$ & 109.0 \\
\hline $\mathrm{H}(2 \mathrm{~A})-\mathrm{C}(2)-\mathrm{H}(2 \mathrm{~B})$ & 107.8 \\
\hline C(2)-C(3)-C(4) & 109.7(3) \\
\hline $\mathrm{C}(2)-\mathrm{C}(3)-\mathrm{H}(3 \mathrm{~A})$ & 109.7 \\
\hline $\mathrm{C}(4)-\mathrm{C}(3)-\mathrm{H}(3 \mathrm{~A})$ & 109.7 \\
\hline C(2)-C(3)-H(3B) & 109.7 \\
\hline $\mathrm{C}(4)-\mathrm{C}(3)-\mathrm{H}(3 \mathrm{~B})$ & 109.7 \\
\hline $\mathrm{H}(3 \mathrm{~A})-\mathrm{C}(3)-\mathrm{H}(3 \mathrm{~B})$ & 108.2 \\
\hline C(3)-C(4)-C(5) & $111.9(2)$ \\
\hline $\mathrm{C}(3)-\mathrm{C}(4)-\mathrm{H}(4 \mathrm{~A})$ & 109.2 \\
\hline $\mathrm{C}(5)-\mathrm{C}(4)-\mathrm{H}(4 \mathrm{~A})$ & 109.2 \\
\hline C(3)-C(4)-H(4B) & 109.2 \\
\hline $\mathrm{C}(5)-\mathrm{C}(4)-\mathrm{H}(4 \mathrm{~B})$ & 109.2 \\
\hline $\mathrm{H}(4 \mathrm{~A})-\mathrm{C}(4)-\mathrm{H}(4 \mathrm{~B})$ & 107.9 \\
\hline$N(1)-C(5)-C(4)$ & $110.7(2)$ \\
\hline N(1)-C(5)-C(19) & $110.1(2)$ \\
\hline$C(4)-C(5)-C(19)$ & $114.0(3)$ \\
\hline $\mathrm{N}(1)-\mathrm{C}(5)-\mathrm{H}(5)$ & 107.3 \\
\hline C(4)-C(5)-H(5) & 107.3 \\
\hline C(19)-C(5)-H(5) & 107.3 \\
\hline$C(11)-C(6)-C(7)$ & $120.3(3)$ \\
\hline$C(11)-C(6)-S(1)$ & $120.1(2)$ \\
\hline$C(7)-C(6)-S(1)$ & $119.6(2)$ \\
\hline $\mathrm{C}(8)-\mathrm{C}(7)-\mathrm{C}(6)$ & 119.2(3) \\
\hline C(8)-C(7)-H(7) & 120.4 \\
\hline $\mathrm{C}(6)-\mathrm{C}(7)-\mathrm{H}(7)$ & 120.4 \\
\hline C(7)-C(8)-C(9) & $122.0(3)$ \\
\hline $\mathrm{C}(7)-\mathrm{C}(8)-\mathrm{H}(8)$ & 119.0 \\
\hline $\mathrm{C}(9)-\mathrm{C}(8)-\mathrm{H}(8)$ & 119.0 \\
\hline
\end{tabular}




\begin{tabular}{|c|c|}
\hline $\mathrm{C}(10)-\mathrm{C}(9)-\mathrm{C}(8)$ & $117.5(3)$ \\
\hline $\mathrm{C}(10)-\mathrm{C}(9)-\mathrm{C}(22)$ & 121.2(3) \\
\hline $\mathrm{C}(8)-\mathrm{C}(9)-\mathrm{C}(22)$ & 121.3(3) \\
\hline $\mathrm{C}(11)-\mathrm{C}(10)-\mathrm{C}(9)$ & $121.8(3)$ \\
\hline $\mathrm{C}(11)-\mathrm{C}(10)-\mathrm{H}(10)$ & 119.1 \\
\hline $\mathrm{C}(9)-\mathrm{C}(10)-\mathrm{H}(10)$ & 119.1 \\
\hline$C(6)-C(11)-C(10)$ & 119.2(3) \\
\hline $\mathrm{C}(6)-\mathrm{C}(11)-\mathrm{H}(11)$ & 120.4 \\
\hline $\mathrm{C}(10)-\mathrm{C}(11)-\mathrm{H}(11)$ & 120.4 \\
\hline$C(13)-C(12)-C(1)$ & 113.6(2) \\
\hline $\mathrm{C}(13)-\mathrm{C}(12)-\mathrm{H}(12 \mathrm{~A})$ & 108.8 \\
\hline $\mathrm{C}(1)-\mathrm{C}(12)-\mathrm{H}(12 \mathrm{~A})$ & 108.8 \\
\hline $\mathrm{C}(13)-\mathrm{C}(12)-\mathrm{H}(12 \mathrm{~B})$ & 108.8 \\
\hline $\mathrm{C}(1)-\mathrm{C}(12)-\mathrm{H}(12 \mathrm{~B})$ & 108.8 \\
\hline $\mathrm{H}(12 \mathrm{~A})-\mathrm{C}(12)-\mathrm{H}(12 \mathrm{~B})$ & 107.7 \\
\hline C(14)-C(13)-C(18) & $117.6(2)$ \\
\hline$C(14)-C(13)-C(12)$ & $121.6(2)$ \\
\hline $\mathrm{C}(18)-\mathrm{C}(13)-\mathrm{C}(12)$ & $120.7(2)$ \\
\hline$C(13)-C(14)-C(15)$ & $121.0(3)$ \\
\hline $\mathrm{C}(13)-\mathrm{C}(14)-\mathrm{H}(14)$ & 119.5 \\
\hline $\mathrm{C}(15)-\mathrm{C}(14)-\mathrm{H}(14)$ & 119.5 \\
\hline$C(16)-C(15)-C(14)$ & 119.9(3) \\
\hline $\mathrm{C}(16)-\mathrm{C}(15)-\mathrm{H}(15)$ & 120.1 \\
\hline $\mathrm{C}(14)-\mathrm{C}(15)-\mathrm{H}(15)$ & 120.1 \\
\hline$C(15)-C(16)-C(17)$ & 119.7(3) \\
\hline $\mathrm{C}(15)-\mathrm{C}(16)-\mathrm{H}(16)$ & 120.1 \\
\hline $\mathrm{C}(17)-\mathrm{C}(16)-\mathrm{H}(16)$ & 120.1 \\
\hline $\mathrm{C}(18)-\mathrm{C}(17)-\mathrm{C}(16)$ & 120.3(3) \\
\hline C(18)-C(17)-H(17) & 119.8 \\
\hline $\mathrm{C}(16)-\mathrm{C}(17)-\mathrm{H}(17)$ & 119.8 \\
\hline C(17)-C(18)-C(13) & 121.4(3) \\
\hline C(17)-C(18)-H(18) & 119.3 \\
\hline $\mathrm{C}(13)-\mathrm{C}(18)-\mathrm{H}(18)$ & 119.3 \\
\hline$C(20)-C(19)-C(5)$ & $112.7(3)$ \\
\hline C(20)-C(19)-H(19A) & 109.0 \\
\hline $\mathrm{C}(5)-\mathrm{C}(19)-\mathrm{H}(19 \mathrm{~A})$ & 109.1 \\
\hline C(20)-C(19)-H(19B) & 109.1 \\
\hline C(5)-C(19)-H(19B) & 109.1 \\
\hline
\end{tabular}




$\begin{array}{ll}\mathrm{H}(19 \mathrm{~A})-\mathrm{C}(19)-\mathrm{H}(19 \mathrm{~B}) & 107.8 \\ \mathrm{C}(21)-\mathrm{C}(20)-\mathrm{C}(19) & 126.9(4) \\ \mathrm{C}(21)-\mathrm{C}(20)-\mathrm{H}(20) & 116.5 \\ \mathrm{C}(19)-\mathrm{C}(20)-\mathrm{H}(20) & 116.5 \\ \mathrm{C}(20)-\mathrm{C}(21)-\mathrm{H}(21 \mathrm{~A}) & 120.0 \\ \mathrm{C}(20)-\mathrm{C}(21)-\mathrm{H}(21 \mathrm{~B}) & 120.0 \\ \mathrm{H}(21 \mathrm{~A})-\mathrm{C}(21)-\mathrm{H}(21 \mathrm{~B}) & 120.0 \\ \mathrm{C}(9)-\mathrm{C}(22)-\mathrm{H}(22 \mathrm{~A}) & 109.5 \\ \mathrm{C}(9)-\mathrm{C}(22)-\mathrm{H}(22 \mathrm{~B}) & 109.5 \\ \mathrm{H}(22 \mathrm{~A})-\mathrm{C}(22)-\mathrm{H}(22 \mathrm{~B}) & 109.5 \\ \mathrm{C}(9)-\mathrm{C}(22)-\mathrm{H}(22 \mathrm{C}) & 109.5 \\ \text { H(22A)-C(22)-H(22C) } & 109.5 \\ \text { H(22B)-C(22)-H(22C) } & 109.5\end{array}$

Symmetry transformations used to generate equivalent atoms:

Table 4. Anisotropic displacement parameters $\left(\AA^{2} \times 10^{3}\right)$ for rowan $1 \mathrm{~m}$. The anisotropic displacement factor exponent takes the form: $-2 \pi^{2}\left[h^{2} a^{* 2} U^{11}+\ldots+2 h k a^{*} b^{*} U^{12}\right]$

\begin{tabular}{lcccccc}
\hline & $\mathrm{U}^{11}$ & $\mathrm{U}^{22}$ & $\mathrm{U}^{33}$ & $\mathrm{U}^{23}$ & $\mathrm{U}^{13}$ & $\mathrm{U}^{12}$ \\
\hline $\mathrm{S}(1)$ & $29(1)$ & $35(1)$ & $25(1)$ & $-1(1)$ & $1(1)$ & $0(1)$ \\
$\mathrm{N}(1)$ & $31(1)$ & $34(1)$ & $25(1)$ & $2(1)$ & $3(1)$ & $5(1)$ \\
$\mathrm{O}(1)$ & $49(1)$ & $32(1)$ & $40(1)$ & $-10(1)$ & $4(1)$ & $-2(1)$ \\
$\mathrm{O}(2)$ & $28(1)$ & $49(1)$ & $33(1)$ & $5(1)$ & $-4(1)$ & $0(1)$ \\
$\mathrm{C}(1)$ & $33(1)$ & $29(2)$ & $25(1)$ & $0(1)$ & $5(1)$ & $-4(1)$ \\
$\mathrm{C}(2)$ & $42(2)$ & $48(2)$ & $36(2)$ & $-1(1)$ & $4(1)$ & $-17(2)$ \\
$\mathrm{C}(3)$ & $47(2)$ & $69(2)$ & $34(2)$ & $2(2)$ & $-7(2)$ & $-23(2)$ \\
$\mathrm{C}(4)$ & $31(2)$ & $69(2)$ & $42(2)$ & $21(2)$ & $-4(1)$ & $-5(2)$ \\
$\mathrm{C}(5)$ & $26(2)$ & $49(2)$ & $36(2)$ & $11(1)$ & $8(1)$ & $8(1)$ \\
$\mathrm{C}(6)$ & $30(1)$ & $33(2)$ & $16(1)$ & $-2(1)$ & $1(1)$ & $2(1)$ \\
$\mathrm{C}(7)$ & $32(2)$ & $36(2)$ & $32(2)$ & $1(1)$ & $3(1)$ & $5(1)$ \\
$\mathrm{C}(8)$ & $50(2)$ & $39(2)$ & $32(2)$ & $3(1)$ & $-1(2)$ & $-5(2)$ \\
$\mathrm{C}(9)$ & $35(2)$ & $58(2)$ & $21(2)$ & $-4(2)$ & $-2(1)$ & $-13(2)$ \\
$\mathrm{C}(10)$ & $28(2)$ & $61(2)$ & $22(1)$ & $-11(2)$ & $-1(1)$ & $0(2)$ \\
$\mathrm{C}(11)$ & $31(1)$ & $39(2)$ & $25(2)$ & $-5(1)$ & $1(1)$ & $3(1)$ \\
$\mathrm{C}(12)$ & $34(2)$ & $28(2)$ & $42(2)$ & $-1(1)$ & $11(1)$ & $-2(1)$ \\
$\mathrm{C}(13)$ & $28(1)$ & $30(2)$ & $29(2)$ & $-2(1)$ & $3(1)$ & $-6(1)$
\end{tabular}




\begin{tabular}{lllllll}
$\mathrm{C}(14)$ & $39(2)$ & $37(2)$ & $27(2)$ & $5(1)$ & $4(1)$ & $3(1)$ \\
$\mathrm{C}(15)$ & $39(2)$ & $39(2)$ & $33(2)$ & $-5(1)$ & $7(1)$ & $4(1)$ \\
$\mathrm{C}(16)$ & $35(2)$ & $25(2)$ & $48(2)$ & $-3(1)$ & $1(1)$ & $2(1)$ \\
$\mathrm{C}(17)$ & $32(2)$ & $39(2)$ & $38(2)$ & $3(1)$ & $-10(1)$ & $-5(1)$ \\
$\mathrm{C}(18)$ & $34(2)$ & $37(2)$ & $24(1)$ & $-4(1)$ & $-1(1)$ & $-8(1)$ \\
$\mathrm{C}(19)$ & $33(2)$ & $40(2)$ & $45(2)$ & $11(1)$ & $10(2)$ & $9(1)$ \\
$\mathrm{C}(20)$ & $41(2)$ & $55(2)$ & $74(3)$ & $15(2)$ & $12(2)$ & $8(2)$ \\
$\mathrm{C}(21)$ & $50(2)$ & $44(2)$ & $107(3)$ & $8(2)$ & $22(2)$ & $9(2)$ \\
$\mathrm{C}(22)$ & $49(2)$ & $88(3)$ & $46(2)$ & $5(2)$ & $1(2)$ & $-29(2)$ \\
& & & & & & \\
\hline
\end{tabular}

Table 5. Hydrogen coordinates ( $\left.\mathrm{x} 10^{4}\right)$ and isotropic displacement parameters $\left(\AA^{2} \times 10^{3}\right)$ for rowan $1 \mathrm{~m}$.

\begin{tabular}{|c|c|c|c|c|}
\hline & $\mathrm{x}$ & $\mathrm{y}$ & $\mathrm{z}$ & $\mathrm{U}(\mathrm{eq})$ \\
\hline $\mathrm{H}(1)$ & 59 & 10783 & 4675 & 35 \\
\hline $\mathrm{H}(2 \mathrm{~A})$ & 2333 & 11142 & 5367 & 50 \\
\hline $\mathrm{H}(2 \mathrm{~B})$ & 929 & 11211 & 6028 & 50 \\
\hline $\mathrm{H}(3 \mathrm{~A})$ & 1695 & 9864 & 6582 & 60 \\
\hline H(3B) & 3241 & 10486 & 6576 & 60 \\
\hline $\mathrm{H}(4 \mathrm{~A})$ & 3996 & 9114 & 6053 & 57 \\
\hline $\mathrm{H}(4 \mathrm{~B})$ & 4210 & 9826 & 5368 & 57 \\
\hline $\mathrm{H}(5)$ & 2942 & 8700 & 4740 & 44 \\
\hline $\mathrm{H}(7)$ & 1587 & 11371 & 3248 & 40 \\
\hline $\mathrm{H}(8)$ & 3792 & 12217 & 2841 & 49 \\
\hline $\mathrm{H}(10)$ & 6796 & 10153 & 2982 & 45 \\
\hline $\mathrm{H}(11)$ & 4609 & 9288 & 3399 & 38 \\
\hline $\mathrm{H}(12 \mathrm{~A})$ & -1826 & 9644 & 5175 & 41 \\
\hline $\mathrm{H}(12 \mathrm{~B})$ & -1035 & 9811 & 6040 & 41 \\
\hline $\mathrm{H}(14)$ & -2530 & 10779 & 6895 & 41 \\
\hline $\mathrm{H}(15)$ & -4487 & 11863 & 7087 & 44 \\
\hline $\mathrm{H}(16)$ & -5547 & 12605 & 5966 & 43 \\
\hline $\mathrm{H}(17)$ & -4714 & 12228 & 4657 & 44 \\
\hline $\mathrm{H}(18)$ & -2806 & 11139 & 4463 & 38 \\
\hline $\mathrm{H}(19 \mathrm{~A})$ & 603 & 8592 & 6035 & 47 \\
\hline $\mathrm{H}(19 \mathrm{~B})$ & 404 & 8072 & 5210 & 47 \\
\hline
\end{tabular}




\begin{tabular}{lrrrr}
$\mathrm{H}(20)$ & 3095 & 7745 & 6286 & 68 \\
$\mathrm{H}(21 \mathrm{~A})$ & 1226 & 6608 & 5462 & 80 \\
$\mathrm{H}(21 \mathrm{~B})$ & 2777 & 6404 & 6054 & 80 \\
$\mathrm{H}(22 \mathrm{~A})$ & 6766 & 12023 & 2010 & 91 \\
$\mathrm{H}(22 \mathrm{~B})$ & 7969 & 11501 & 2584 & 91 \\
$\mathrm{H}(22 \mathrm{C})$ & 7071 & 12337 & 2914 & 91 \\
\hline
\end{tabular}

Crystal data for $\mathrm{C}_{22} \mathrm{H}_{27} \mathrm{NO}_{2} \mathrm{~S} ; \mathrm{M}=369.51$. Crystallises from hexane as colourless blocks; crystal dimensions $0.41 \times 0.32 \times 0.28 \mathrm{~mm}^{3}$. Orthorhombic, $a=8.084(3) b=$ 15.313(6) $c=16.268(6) \AA, U=2013.7(14) \AA^{3}, Z=4, D_{C}=1.219 \mathrm{Mg} / \mathrm{m}^{3}$, space group $\mathrm{P}_{2}{ }_{2}{ }_{1}{ }_{1}\left(D_{2}^{4}\right.$, No.19), Mo-K $\alpha$ radiation $(\bar{\lambda}=0.71073 \AA), \mu\left(\mathrm{Mo}_{\alpha} \mathrm{K}_{\alpha}\right)=0.176$ $\mathrm{mm}^{-1}, \mathrm{~F}(000)=792$.

Data collected were measured on a Bruker Smart CCD area detector with Oxford Cryosystems low temperature system. Cell parameters were refined from the setting angles of 898 reflections ( $\theta$ range $1.83<27.57^{\circ}$ ).

Reflections were measured from a hemisphere of data collected of frames each covering 0.3 degrees in omega. Of the 23080 reflections measured, all of which were corrected for Lorentz and polarisation effects and for absorption by semi empirical methods based on symmetry-equivalent and repeated reflections (minimum and maximum transmission coefficients 0.9313 and 0.9542), 3242 independent reflections exceeded the significance level $|\mathrm{F}| / \sigma(|\mathrm{F}|)>4.0$. The structure was solved by direct methods and refined by full matrix least squares methods on $\mathrm{F}^{2}$. Hydrogen atoms were placed geometrically and refined with a riding model (including torsional

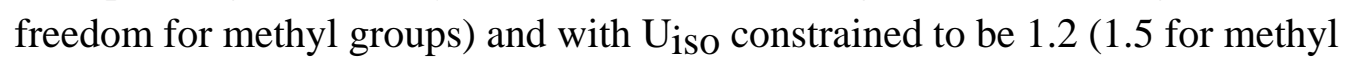
groups) times $\mathrm{U}_{\text {eq }}$ of the carrier atom. Refinement converged at a final $\mathrm{R}=0.0476$ $\left(\mathrm{wR}_{2}=0.1006\right.$, for all 4566 data, 236 parameters, mean and maximum $\delta / \sigma 0.000,0.000)$ with allowance for the thermal anisotropy of all non-hydrogen atoms. Minimum and maximum final electron density -0.354 and 0.543 e. $\AA^{-3}$. A weighting scheme $\mathrm{w}=1 /\left[\sigma^{2}\left(\mathrm{Fo}^{2}\right)+(0.0265 * \mathrm{P})^{2}+1.0450 * \mathrm{P}\right]$ where $\mathrm{P}=\left(\mathrm{Fo}^{2}+2 *\right.$ $\left.\mathrm{Fc}^{2}\right) / 3$ was used in the latter stages of refinement. Complex scattering factors were taken from the program package SHELXTL ${ }^{Y}$ as implemented on the Viglen Pentium computer.

Reference Y SHELXTL version, An integrated system for solving and refining crystal structures from diffraction data (Revision 5.1), Bruker AXS LTD 


\section{Supplementary material}

anisotropic thermal vibrational parameters with e.s.d.s

hydrogen atom position parameters

observed structure amplitudes and calculated structure factors. 